\title{
"Avaliação quantitativa e qualitativa da matéria orgânica de solo sob a aplicação de efluente de esgoto tratado em biodigestor anaeróbio"
}

\author{
Lilian Fernanda de Almeida Martelli
}

Dissertação apresentada ao Instituto de Química de São Carlos, Universidade de São Paulo, para obtenção do título de Mestre em Química (Área de concentração: Química Analítica)

Orientador: Dr. Wilson Tadeu Lopes da Silva (Embrapa Instrumentação Agropecuária) 
Este exemplar foi revisado e alterado em relação à versão original, sob a exclusiva responsabilidade do autor.

São Carlos, 13/05/2011

Lilian Fernanda A. Martelli 
"(...)Mas, quanto a mim, tenho a lhes dizer que as estrelas são mais do que curumins. Estrelas são os olhos de Deus vigiando para que corra tudo bem. Para sempre. E, como se sabe, 'sempre' não acaba nunca."

(Clarice Lispector)

"O que torna belo o deserto - disse o principezinho - é que ele esconde um poço em algum lugar."

(Antoine de Saint-Exupéry - "O pequeno príncipe") 
"(...)Tu sabes bem que em meu barco

Eu não tenho nem ouro nem espadas

Somente redes e o meu trabalho (...)"

(Pe. Zezinho - "A Barca")

\begin{abstract}
À Deus, por suas incansáveis maravilhas Aos meus pais, Edson e Ana, e ao meu irmão Ju Aos meus avós lindos, Idalina e Oswaldo, meu segundo pai e minha segunda mãe, Ao meu querido esposo Fabrício

OFEREÇO E DEDICO...
\end{abstract}




\section{AGRADECIMENTOS:}

A Deus e Nossa Senhora, pela proteção e luz a me guiar e pela realização deste trabalho.

Ao Dr. Wilson Tadeu Lopes da Silva pela orientação, amizade, confiança $e$ prontidão de sempre durante toda a realização do meu estágio na Embrapa CNPDIA e na realização deste trabalho.

Ao Renê e Silviane, pelos intermináveis auxílios nos laboratórios e equipamentos sempre que necessitei e pela seriedade em seus trabalhos.

À Joana Bresolin, pelas coletas, auxílios, sugestões e companhia tão agradável nas visitas à Cabrália Paulista.

À Adriana Thomazi pela paciência e atenção na utilização de equipamentos e sua enorme boa vontade em ajudar.

Ao Valentim e ao Dr. Marcelo Simões, e a todos os funcionários da Embrapa Instrumentação Agropecuária, por tornar a convivência profissional mais harmoniosa $e$ agradável.

À ETEC Astor de Mattos Carvalho, em Cabrália Paulista-SP, em especial ao diretor Lourenço Magnoni-Jr, ao professor Edson e aos alunos envolvidos no projeto Biodigestor, por toda a receptividade, dedicação e acompanhamento do experimento de campo e auxílio incomparável nas coletas, tarefas estas que foram essenciais para toda a condução deste trabalho.

Aos meus pais Edson e Ana, pela dedicação e todos os sacrifícios que passaram para que eu pudesse estudar e realizar mais este sonho, e ao meu irmão Juninho.

Aos meus avós Idalina e Oswaldo, por serem tão graciosos e possibilitarem que eu aprendesse, entre muitas coisas, algo que foi além de cursos e universidades: simplicidade, humildade e caráter.

Ao meu querido esposo Fabrício, pela companhia, dedicação, amor e paciência, e por estar ao meu lado.

A todos os colegas da Embrapa Instrumentação Agropecuária, àqueles que já passaram ou ainda estão por lá; em especial à Adriana Faustino, Juliana Scramin, Lívia, Tânia e Vivian; a todos os demais colegas, Cléber, Tassiane, Gabriela Carósio, Fernanda, Larissa, Úrsula, Aline, Juliana Manieri, Leandro, Natália Galindo, Tatiana, Mariani, Fernando, Francys, e muitos outros, obrigada pelo harmonioso convívio e amizade.

Às minhas amigas de todas as horas, inclusive parceiras de últimas-análises-atémeia-noite, Ju, Lívia e Tânia, por serem tão especiais, agradeço pelas alegrias, tristezas, companheirismo e cumplicidade.

$\grave{A}$ todos os meus amigos que conquistei ao longo da minha vida em especial Timel, Ferzoca, Fer, Lu, Cabelinho, Alex, entre outros, e meus familiares..., e a todos os outros que a memória neste momento tenha falhado.....em algum momento eles certamente me incentivaram e me trouxeram alegrias, e estão, um a um, guardados em meu coração! 
À Comunidade Sagrada Família, Solange, Layra, Lucas, Giulia, Josi, Renilda, Leandro, Eliana, Nelsinho, Toninho, Cris e todos os demais pelo convívio e ensinamentos de família, amizade e paz, e pelo incentivo.

Ao Instituto de Química de São Carlos, pela excelência e oportunidade da realização de mais este sonho em minha vida.

Ao $\mathrm{CNPq}$, pelo auxílio concedido.

Confesso ser praticamente impossivel listar aqui tudo e todos aqueles a quem devo agradecer....mas agradeço, de coração a todos que direta ou indiretamente contribuíram para minha existência neste lugar!

$O$ meu sincero Muito obrigada! 


\section{SUMÁRIO}

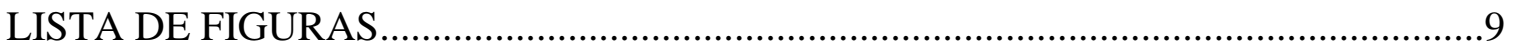

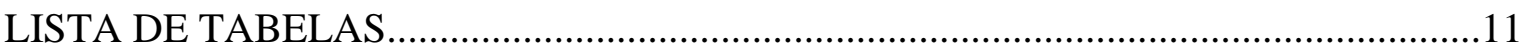

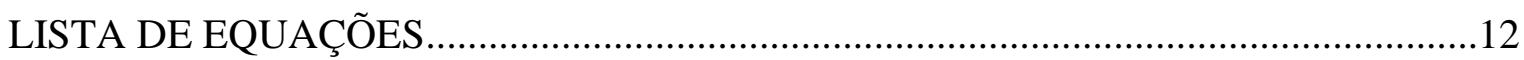

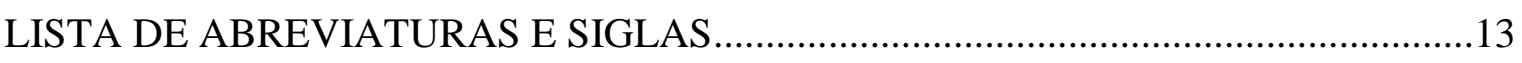

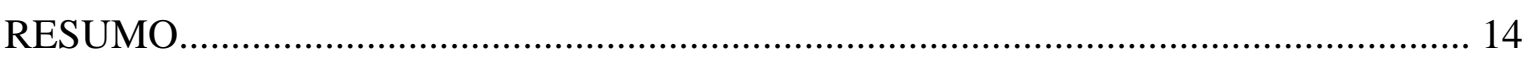

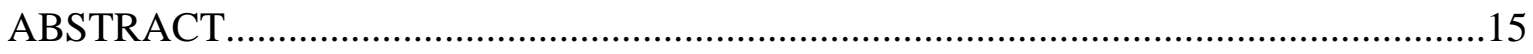

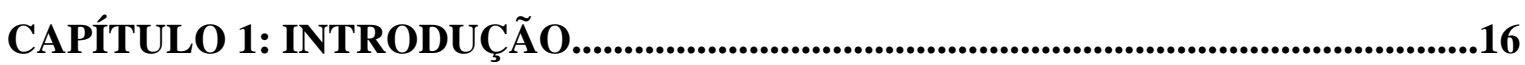

CAPÍTULO 2: REVISÃO DA LITERATURA..........................................................21

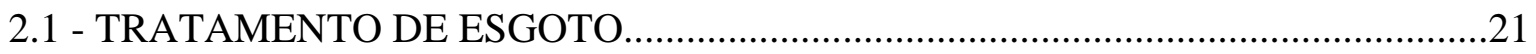

2.1.1 - PROCESSOS BIOLÓGICOS: A DIGESTÃO ANAERÓBIA...................................23

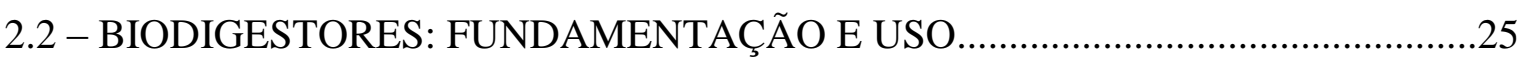

2.3 - A QUÍMICA ENVOLVIDA NO COMPARTIMENTO SOLO.................................28

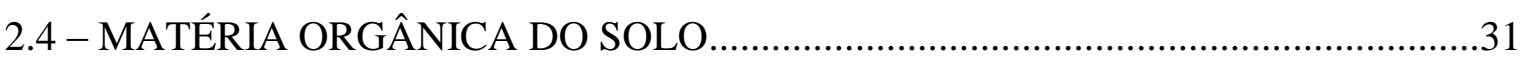

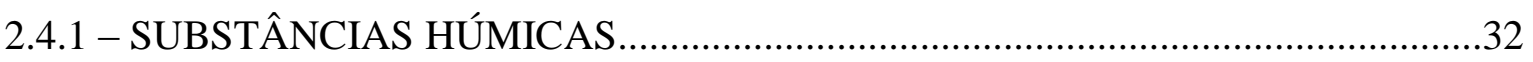

2.4.1.1 - O MODELO MACROMOLECULAR DAS SUBSTÂNCIAS HÚMICAS.........34

2.4.1.2 - O MODELO SUPRAMOLECULAR DAS SUBSTÂNCIAS HÚMICAS............37

2.5 - APLICAÇÃO DE RESÍDUOS NO SOLO.................................................................39

2.5.1 - EFLUENTE DE ESGOTO TRATADO:

APLICAÇÃO AGRÍCOLA E POSSÍVEIS IMPACTOS ....................................................

2.5.2 - BREVE DESCRIÇÃO DA LEGISLAÇÃO PERTINENTE À

APLICAÇÃO DE EFLUENTES NO SOLO......................................................................

2.6 - DETERMINAÇÃO DA MATÉRIA ORGÂNICA DO SOLO.....................................43

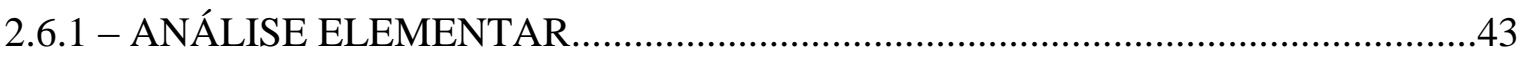

2.6.2 - MÉTODO WALKLEY-BLACK.............................................................................

2.7 - MÉTODOS ESPECTROSCÓPICOS.......................................................................

2.7.1 - ESPECTROSCOPIA NA REGIÃO DO INFRAVERMELHO MÉDIO COM TRANSFORMADA DE FOURIER (FTIR) …………………..........................................46

2.7.2 - ESPECTROSCOPIA NA REGIÃO DO INFRAVERMELHO PRÓXIMO (NIRS)....49

2.7.3 - ESPECTROSCOPIA DE FLUORESCÊNCIA EM SOLUÇÃO...................................50

2.7.3.1 - MODALIDADE DE EMISSÃO......................................................................52

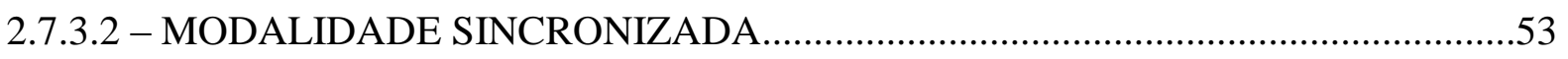

2.7.4 - ESPECTROSCOPIA DE FLUORESCÊNCIA INDUZIDA POR LASER (FIL).........54 
2.8 - POTENCIAL ZETA E MEDIDA DE TAMANHO DE PARTÍCULA.

CAPÍTULO 3 - OBJETIVOS.

CAPÍTULO 4 - MATERIAIS E MÉTODOS...........................................................................65

4.1 - DESCRIÇÃO DO CAMPO EXPERIMENTAL .......................................................65

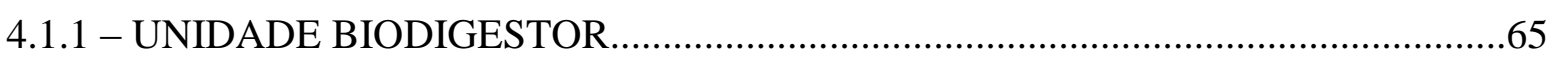

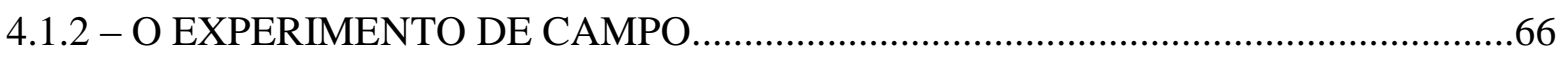

4.2 - COLETAS E ANÁLISES DAS AMOSTRAS DE EFLUENTE TRATADO PELO

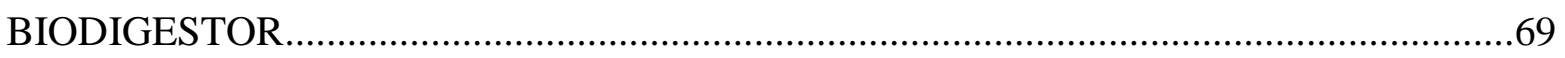

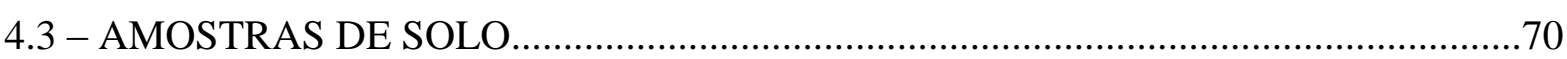

4.3.1 - AMOSTRAGEM E PREPARO DAS AMOSTRAS.................................................... 70

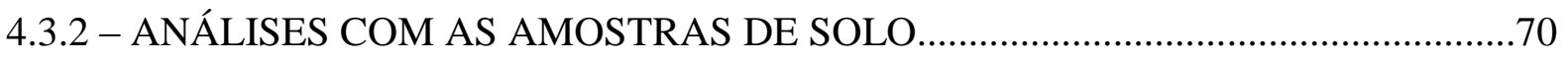

4.3.2.1 - CONDUTIVIDADE E pH DO EXTRATO DO SOLO ............................................70

4.3.2.2 - DETERMINAÇÃO DO TEOR DE MATÉRIA ORGÂNICA POR VIA ÚMIDA OU

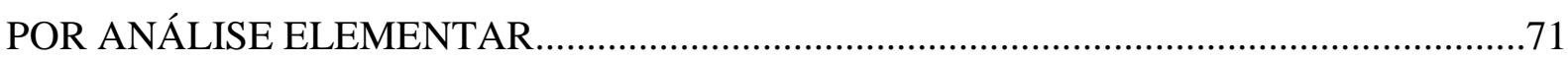

4.3.2.3 - ESPECTROSCOPIA DE FLUORESCÊNCIA INDUZIDA POR LASER...............71

4.3.2.4 - ESPECTROSCOPIA NA REGIÃO DO INFRAVERMELHO PRÓXIMO.............72

4.4 - AMOSTRAS DE ÁCIDOS HÚMICOS EXTRAÍDOS DO SOLO................................72

4.4.1 - EXTRAÇÃO E FRACIONAMENTO DE ÁCIDOS HÚMICOS DO SOLO...............72

4.4.2 - ANÁLISES COM OS ÁCIDOS HÚMICOS EXTRAÍDOS DO SOLO......................73

4.4.2.1 - ESPECTROSCOPIA NA REGIÃO DO INFRAVERMELHO MÉDIO COM

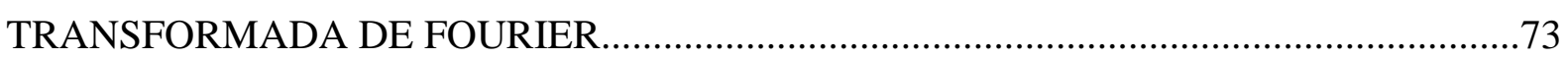

4.4.2.2 - ESPECTROSCOPIA DE FLUORESCÊNCIA EM SOLUÇÃO: MODALIDADES

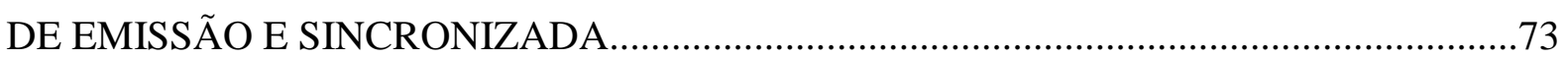

4.4.2.3 - MEDIDA DE TAMANHO DE PARTÍCULAS E POTENCIAL ZETA..................74

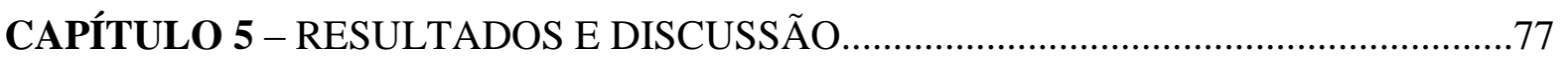

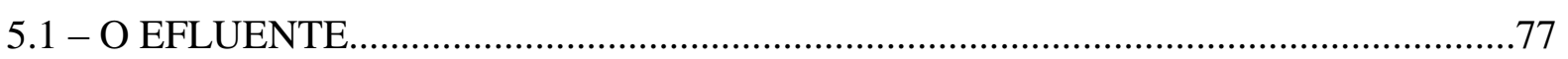

5.1.1 - PARÂMETROS FÍSICO-QUÍMICOS E ENSAIOS MICROBIOLÓGICOS............77

5.1.2 - CONCENTRAÇÃO DE MACRO E MICRONUTRIENTES...................................80

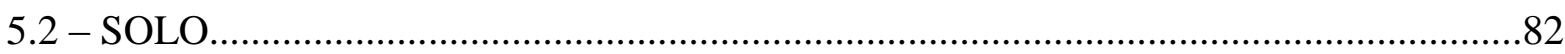

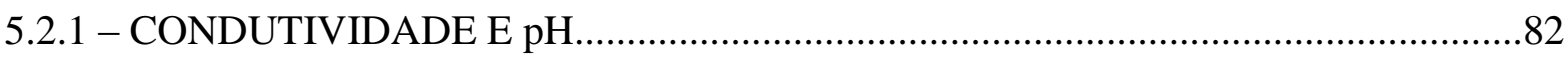

5.2.2 - DETERMINAÇÃO DO TEOR DE MATÉRIA ORGÂNICA VIA ÚMIDA E POR

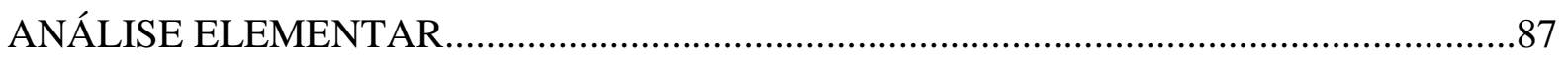

5.2.3 - ESPECTROSCOPIA NA REGIÃO DO INFRAVERMELHO PRÓXIMO...............88

5.2.4 - ESPECTROSCOPIA DE FLUORESCÊNCIA INDUZIDA POR LASER (FIL).......91 
5.3 - MATÉRIA ORGÂNICA DO SOLO: ÁCIDOS HÚMICOS EXTRAIIDOS . .92

5.3.1 - ESPECTROSCOPIA NA REGIÃO DO INFRAVERMELHO MÉDIO COM TRANSFORMADA DE FOURIER . .92

5.3.2 - ESPECTROSCOPIA DE FLUORESCÊNCIA EM SOLUÇÃO: MODALIDADES DE EMISSÃO E SINCRONIZADA. .95

5.3.3 - MEDIDA DE TAMANHO DE PARTÍCULAS E POTENCIAL ZETA.. . .99

CAPÍTULO 6 - CONCLUSÕES. .108 REFERÊNCIAS.. . .110 


\section{LISTA DE FIGURAS}

Figura 1: Percentual de municípios com tratamento de esgoto, em ordem decrescente,

segundo as $\quad$ Unidades da $\quad$ Federação

2008 .

Figura 2 : Esquema da via de degradação anaeróbia da matéria orgânica.

Figura 3: Biodigestor de modelo Chinês

Figura 4: Biodigestor de modelo Indiano

Figura 5: Biodigestor de modelo Canadense.

Figura 6: Representação de um solo (adaptado de MANAHAN, 1994)

Figura 7: Estrutura de um agregado de solo com destaque ao papel cimentante e agregador da matéria orgânica e dos microrganismos em interação com partículas de areia e argila.

Figura 8: Modelo de estrutura macromolecular para ácido húmico proposto por SCHULTEN e SCHNITZER (1993).

Figura 9: Modelo tridimensional de ácido húmico proposto por SCHULTEN e SCHNITZER (1997). .36

Figura 10: Microscopia Eletrônica de Varredura apresentando as conformações estruturais de um ácido húmico extraído de solo, onde (a) representa a conformação retraída em meio ácido (pH 3) e (b) refere-se à conformação expandida em meio neutro $(\mathrm{pH} 7)$

Figura 11: Esquema de estrutura das SH proposto por SIMPSON et al. (2002), unidades vermelhas: cátions metálicos; unidades pretas: polissacarídeos; unidades azuis: polipeptídios; unidades verdes: cadeias alifáticas e unidades marrons: fragmentos aromáticos.

Figura 12: Vibrações típicas de átomos. A. Vibrações de estiramento; B. e C. Vibrações de deformação angular.

Figura 13: Espectro típico de ácido húmico.

Figura 14: Níveis vibracionais e eletrônicos de uma molécula orgânica, e caminhos de decaimento radiativos e não radiativos.

Figura 15: Espectro de emissão de fluorescência de AH extraídos de solo tratado com lodo de esgoto, obtido segundo metodologia de MILORI et al., (2002).

Figura 16: Espectro de varredura sincronizada de AH extraídos de solo tratado com lodo de esgoto, obtido segundo metodologia de KALBITZ et al., (2000). 
Figura 18: Esquema da montagem do sistema FIL portátil.

Figura 19: Representação da dupla camada elétrica e da variação do potencial Zeta com a distância de uma partícula carregada negativamente.

Figura 20: Curva de potencial Zeta em função de $\mathrm{pH}$.

Figura 21: Cela capilar com eletrodo. Em destaque o movimento de cargas na camada Estacionária.

Figura 22: Figura de interferência formada, utilizada para medida de mobilidade eletroforética em sistemas mais modernos

Figura 23: Medida de mobilidade eletroforética em sistemas mais modernos.

Figura 24: Unidade modelo de biodigestor anaeróbio instalado na ETEC Astor de Mattos Carvalho.

Figura 25: Delineamento do campo experimental

Figura 26: Representação das parcelas em um dos blocos.

Figura 27: (a) Após preparo do solo, início do plantio e primeira irrigação e (b) Cultivo de sorgo em uma das parcelas- dosagem de efluente 50\% acima da recomendada, ilustrando como as parcelas estavam identificadas para auxílio na irrigação.

Figura 28: Esquema do biodigestor e de seus cinco pontos de coleta.

Figura 29: Valores de pH obtidos em água e em solução de Cloreto de Cálcio para as amostras de solo em tratamentos diferentes e nas profundidades estudadas.

Figura 30: Valores de condutividade $\left(\mathrm{em} \mu \mathrm{S} \mathrm{cm}^{-1}\right.$ ) obtidos para as amostras nos diferentes tratamentos e profundidades.

Figura 31: Teores de matéria orgânica obtidos para as amostras nas profundidades de $0-10 \mathrm{~cm}$ e $80-100 \mathrm{~cm}$

Figura 32: Gráfico dos valores de teor de carbono preditos vs medidos para as amostras de solo estudadas.

Figura 33: Espectros de NIRS obtidos para algumas amostras em 0-10 cm (TEST, AM, E100 e CC) apresentando as bandas características observadas. 
Figura 34: Gráfico obtido evidenciando regiões do espectro (de 10000 a $4000 \mathrm{~cm}^{-1}$ ) de maior sensibilidade e resposta para obtenção do modelo.

Figura 35: Índices de humificação obtidos para as amostras nos diferentes tratamentos e profundidades, segundo metodologia proposta por (MILORI et al.,2004).

Figura 36: Espectros obtidos por infravermelho médio com Transformada de Fourier para algumas amostras de ácido húmico extraídas dos solos estudados, nos tratamentos TEST, AM, E100 e CC, na profundidade de $0-10 \mathrm{~cm}$.

Figura 37: Gráfico da PC1 vs. PC2, representando a separação das amostras por semelhança e tendência de grupamentos.

Figura 38: Espectros obtidos por meio da modalidade de emissão, segundo metodologia de (MILORI et al., 2002), de algumas amostras de ácido húmico extraídas dos solos estudados, para os tratamentos TEST, AM, E100 e CC na profundidade de $0-10 \mathrm{~cm}$.

Figura 39: Gráficos dos índices de humificação $\left(\mathrm{A}_{465}\right)$ obtidos para as amostras dos diferentes tratamentos nas seis profundidades estudadas. .96

Figura 40: Espectros obtidos por meio da modalidade sincronizada, segundo metodologia de (KALBITZ et al., 2000), de algumas amostras de ácido húmico extraídas dos solos estudados, para os tratamentos TEST, AM, E100 e CC na profundidade de $0-10 \mathrm{~cm}$

Figura 41: Gráficos dos índices de humificação $\left(\mathrm{I}_{470} / \mathrm{I}_{377}\right)$ obtidos para as amostras dos diferentes tratamentos nas seis profundidades estudadas .98

Figura 42: Gráfico de Efeitos vs. Z scores calculados, obtidos através dos resultados da análises realizadas estabelecidas pelo planejamento fatorial

Figura 43: Respostas obtidas para potencial Zeta alternando-se as variáveis do nível inferior para o superior. 100

Figura 44: Respostas obtidas para tamanho de partículas alternando-se as variáveis do nível inferior para o superior.

Figura 45: Respostas obtidas para medidas de tamanho de partículas alternando-se as variáveis do nível inferior para o superior. 101

Figura 46: Gráficos das distribuições de tamanho pela intensidade das amostras TEST, nas seis profundidades estudadas e em $\mathrm{pH}$ igual a 2,7 e 12 , respectivamente..... 105 
Figura 47: Gráficos das distribuições de tamanho pela intensidade das amostras AM, nas seis profundidades estudadas e em $\mathrm{pH}$ igual a 2, 7 e 12, respectivamente. 106

Figura 48: Gráficos das distribuições de tamanho pela intensidade das amostras E100, nas seis profundidades estudadas e em $\mathrm{pH}$ igual a 2,7 e 12 , respectivamente. 106 
Tabela 1: Bandas no infravermelho do ácido húmico .48

Tabela 2: Bandas de absorção das vibrações de estiramento dos principais grupos funcionais no espectro de infravermelho próximo $\left(\mathrm{cm}^{-1}\right)$

Tabela 3: Descrição das amostras e tratamentos aplicados nas parcelas

Tabela 4: Volume de efluente e água e concentração de adubação mineral aplicados a cada um dos tratamentos.

Tabela 5: Variáveis de estudo e níveis investigados do menor (-) para maior (+)

Tabela 6: Relação dos experimentos conduzidos e suas condições .75

Tabela 7: Temperatura $\left({ }^{\circ} \mathrm{C}\right)$ da solução nos diferentes pontos de amostragem e em diferentes períodos do ano. .77

Tabela 8: Valores de $\mathrm{pH}$ da solução nos diferentes pontos de amostragem e em diferentes períodos do ano. .78

Tabela 9: Oxigênio Dissolvido $\left(\mathrm{mg} \mathrm{L}^{-1}\right)$ da solução nos diferentes pontos de amostragem e em diferentes períodos do ano .78

Tabela 10: Potencial redox $(\mathrm{mV})$ da solução nos diferentes pontos de amostragem e em diferentes períodos do ano

Tabela 11: Condutividade Elétrica $\left(\mathrm{mS} \mathrm{cm}^{-1}\right)$ da solução nos diferentes pontos de amostragem e em diferentes períodos do ano

Tabela 12: Resultado representativo das análises físico-químicas e microbiológicas do efluente na entrada e saída do biodigestor (análise realizada em 19/11/2008). .80

Tabela 13: Elementos de interesse presentes no efluente tratado (ponto 5). .81 
Tabela 14: Intensidade de partículas, faixas de tamanho e tamanhos médios para as amostras TEST, nas diferentes profundidades

Tabela 15: Intensidade de partículas, faixas de tamanho e tamanhos médios para as amostras $\mathrm{AM}$, nas diferentes profundidades. 104

Tabela 16: Intensidade de partículas, faixas de tamanho e tamanhos médios para as amostras E100, nas diferentes profundidades 105 


\section{LISTA DE EQUAÇÕES}

Equação 1: Determinação do Oxigênio via análise elementar. .44

Equação 2: Reação da oxidação da MOS .45

Equação 3: Reação de titulação entre o excesso de dicromato com íons $\mathrm{Fe}^{2+}$ .45

Equação 4:Equação de Henry.... .60

Equação 5: Equação de Stokes-Einstein. .62

Equação 6: Cálculo de efeitos principais. 76 


\section{LISTA DE ABREVIAÇÕES E SIGLAS}

$\begin{array}{ll}\text { ACF } & \text { Área do Espectro de Emissão de FIL } \\ \text { AF } & \text { Ácidos Fúlvicos } \\ \text { AH } & \text { Ácidos Húmicos } \\ \text { CETESB } & \text { Companhia de Tecnologia de Saneamento Ambiental } \\ \text { CONAMA } & \text { Conselho Nacional do Meio Ambiente } \\ \text { COT } & \text { Carbono Orgânico Total } \\ \text { CTC } & \text { Capacidade de Troca Catiônica } \\ \text { Da } & \text { Daltons } \\ \text { DBO } & \text { Demanda bioquímica de Oxigênio } \\ \text { DQO } & \text { Demanda Química de Oxigênio } \\ \text { FIL } & \text { Fluorescência Induzida por Laser } \\ \text { FTIR } & \text { Infravermelho com Transformada de Fourier } \\ \text { HU } & \text { Humina } \\ \text { IBGE } & \text { Instituto Brasileiro de Geografia e Estatística } \\ \text { ICP- OES } & \text { Espectrometria de Emissão Ótica com Plasma Acoplado Indutivamente } \\ \text { IHSS } & \text { Sociedade Internacional de Substâncias Húmicas } \\ \text { MOS } & \text { Matéria Orgânica do Solo } \\ \text { OD } & \text { Oxigênio Dissolvido } \\ \text { SH } & \text { Substâncias Húmicas } \\ \text { TFSA } & \text { Terra Fina Seca ao Ar } \\ \end{array}$




\section{RESUMO}

Uma das alternativas encontradas para a reutilização de efluentes de esgotos tratados é o emprego deste material na agricultura como adubo orgânico, podendo substituir total ou parcialmente a adubação mineral. Essa prática, que se constitui de benefícios no que tange à reciclagem de nutrientes, representa uma economia de água no setor agrícola, estimada em cerca de $70 \%$ do consumo total no Brasil. Neste trabalho, pretendeu-se investigar o impacto na matéria orgânica do solo, submetido à irrigação com efluente proveniente de um biodigestor anaeróbio.

Através da realização de um experimento de campo, sob o cultivo de sorgo, realizou-se a comparação, em relação à matéria orgânica, de amostras de solo que receberam irrigação em dosagens diferenciadas do efluente tratado àquela de um solo "testemunha" (branco), o qual recebeu apenas irrigação com água ao longo do experimento e de um solo que recebeu anteriormente adubação convencional, segundo as recomendações do Instituto Agronômico de Campinas (IAC). Estabeleceu-se, ainda, comparações com amostras de solo coletadas na mesma propriedade. Avaliou-se a estabilidade (humificação) da matéria orgânica, como indicadora da capacidade fertilizante do efluente, quando incorporado ao solo. A qualidade do efluente do biodigestor foi acompanhada antes do início do experimento, de modo a verificar suas características principais e particularidades.

A utilização de ferramentas como a PCA e planejamento fatorial foi de grande relevância para a análise dos resultados e condução dos experimentos.

As técnicas químicas e espectroscópicas mostraram que o benefício proporcionado pela adição de efluente ao solo, mesmo em um experimento de curta duração, pode apresentar alterações, mesmo que não sejam tão pronunciadas.

Os resultados obtidos para amostras de ácidos húmicos em relação ao tamanho de partículas evidenciaram um comportamento notado em estudos bastante recentes, em relação à estrutura das substâncias húmicas. 


\section{ABSTRACT}

An alternative found for treated sewage effluents reuse is to apply this material in agriculture as a fertilizer, in order to replace totally or partially the mineral fertilizers. This practice, beyond inherent benefits due to nutrients recycling promotes agricultural water reuse, which is responsible of around $70 \%$ of the total water consumption in Brazil. In this work, it was intended to investigate the soil organic matter impact, under irrigation using effluent from an anaerobic biodigester. Through a field experiment under "sorgo" culture, a comparison was established, related to the soil organic matter, of soil samples that had been applied different treated effluent concentrations to soil samples that received only water ("testemunha"- blank) or water and mineral fertilizer according to the Campinas Agronomic Institute recommendations. Other comparisons, among soil samples under citrus culture were also established. The soil organic matter humification was evaluated, as an indication of the effluent fertilizing ability when applied in soil. The biodigester effluent features were checked before the experiment beginning, in order to verify its mais features and particularities.

Tools as Principal component Analysis and factorial design were of such relevance for the results analysis and experiments execution.

The spectroscopic and chemical techniques showed that the benefits from the effluent addition in soil, even in a short-term experiment, can present changes.

The results for the humic acids samples concerning the particles size evidenced the behavior presented in recent studies, related to humic substances structures. 


\section{CAPÍTULO 1: INTRODUCÃ̃}

A atual percepção abrangendo a questão de "recursos hídricos" destaca a sua demanda cada vez maior, decorrente do contínuo crescimento populacional, associada à poluição de águas, às secas sazonais que afetam determinadas regiões do planeta e à distribuição desigual deste recurso natural. São estes fatores que têm estimulado pesquisas sobre novas formas de recuperação e suprimento de água. Entre as diferentes alternativas utilizadas pelas sociedades contemporâneas para solucionar ou minimizar este problema, o reuso de águas residuárias evidencia-se como uma opção viável econômica e ambientalmente (BROWN et al., 2000).

Em todo o mundo, devido a sua escassez, existe uma crescente competição pelo uso de água entre diversos setores da sociedade. O consumo de água na agricultura é grande em relação a outros tipos de uso, podendo afetar a disponibilidade deste recurso para a população urbana se este não for bem administrado. No Brasil, a agricultura consome cerca de $61 \%$ da água doce total (CHRISTOFIDIS, 2001).

Diante da necessidade da agricultura e a viabilidade do emprego de efluentes tratados no solo, é de fundamental importância que o reuso da água seja avaliado, bem como as condições nas quais o efluente é aplicado ao solo. Devido a sua capacidade fertilizante, este material vem sendo indicado no preparo de solos e na adubação de plantações, como pomares, apresentando efeito comparável ao da adubação química mineral à base de nitrogênio, fósforo e potássio, a um custo praticamente zero, já que se trata de um material residual, oriundo do processo de tratamento de esgotos. $\mathrm{O}$ efluente fornece às plantas macronutrientes $\mathrm{e}$ micronutrientes, e dessa forma contribui para uma agricultura sustentável.

Para as condições brasileiras, a reutilização com finalidade agrícola do esgoto sanitário tratado apresenta vários aspectos positivos em função da influência de um clima tropical, que expõe o solo à intensa atividade intempérica, proporcionando uma rápida mineralização da matéria orgânica. Sob este ponto de vista, considera-se a matéria orgânica como um conjunto de substâncias altamente heterogêneas que inclui numerosos compostos de carbono, variando de açucares, proteínas e outros constituintes biológicos, ácidos orgânicos de baixas massas moleculares, como ácidos acético e oxálico, quase todos facilmente mineralizáveis, até um conjunto complexo de produtos recalcitrantes resultantes de transformações química e microbiana da matéria orgânica do solo (MOS) (BUDZIAK et al., 2004). Essa mineralização atua na disponibilidade de uma gama de nutrientes ao meio, podendo ainda contribuir para a elevação do pH do solo e a redução da acidez potencial, (SIMONETE et al., 2003). 
Sabe-se que ainda muitas regiões do Brasil carecem de sistemas de tratamento de esgoto, e os dejetos oriundos de atividades como a suinocultura aumentam severamente as preocupações com a contaminação do solo e corpos d'água. A sustentabilidade tão requerida, é potencializada e favorecida quando ações ocorrem conjuntamente: tratamento, impedimento de contaminações e utilização do efluente tratado como insumo na agricultura. Dentro deste contexto, a Embrapa Instrumentação Agropecuária em parceria com a Firestone Building Products e o Centro Paula Souza instalou uma unidade modelo de biodigestor nas dependências de uma escola técnica agrícola da cidade de Cabrália Paulista-SP, promovendo o tratamento do esgoto proveniente de dejetos humanos e da criação de suínos existente na escola. O efluente resultante do tratamento anaeróbio foi empregado como biofertilizante no solo.

Como anteriormente mencionado, as características que constituem de modo geral os efluentes tratados, tornam este material algo atraente para aplicação na agricultura. Entretanto, deve ser levado em consideração que as peculiaridades dos efluentes tratados, como suas composições químicas, podem ser fatores de atenção e até preocupação, uma vez que, se aplicados descontroladamente podem atuar como contaminantes ao serem percolados pelo solo, atingindo lençóis subterrâneos e corpos d'água. Ademais, efeitos considerados negativos podem ocorrer no que diz respeito, por exemplo, às características químicas do solo.

Assim sendo, é de extrema relevância que estudos sejam cada vez mais intensamente conduzidos com o propósito de se estabelecer parâmetros de dosagens e aplicações e profundo conhecimento acerca dos diferentes efeitos que os mais diversos tipos de efluentes possam causar. 


\section{CAPÍTULO 2: REVISÃO DA LITERATURA}

\section{1 - TRATAMENTO DE ESGOTO}

A crescente demanda populacional infere na maior preocupação no que diz respeito a esgotamento sanitário. No Brasil, apesar do avanço na implantação de redes coletoras de esgoto e de municípios brasileiros com sistema de tratamento de esgoto, há ainda muito o que expandir e englobar, pois um número considerável de municípios nas diversas regiões do país carecem tanto da coleta quanto do tratamento de esgoto.

Segundo dados obtidos pela mais recente Pesquisa Nacional de Saneamento Básico realizada pelo IBGE - Instituto Brasileiro de Geografia e Estatística- (IBGE, 2008), à exceção do Distrito Federal, em apenas três Unidades da Federação, mais da metade dos municípios possuíam tratamento de esgoto: São Paulo (78,4\%); Espírito Santo (69,2\%); e Rio de Janeiro $(58,7 \%)$. O Estado do Ceará $(48,9 \%)$ obteve a marca mais elevada da Região Nordeste; na Região Centro-Oeste, destacou-se o Estado do Mato Grosso do Sul (43,6\%); e, na Região Sul, o Estado do Paraná (41,1\%). Em cinco Unidades da Federação, a proporção de municípios com tratamento de esgoto foi inferior a 10\%: Sergipe (9,3\%); Amazonas (4,8\%); Pará (4,2\%); Rondônia (3,8\%); Piauí (2,2\%); e Maranhão (1,4\%). Os Estados de Minas Gerais $(22,7 \%)$ e Rio Grande do Sul (15,1\%), importantes do ponto de vista econômico, tiveram resultados inferiores à média nacional $(28,5 \%)$, conforme ilustrado a seguir na Figura 1.

Ainda segundo dados do IBGE, de 2000 a 2008, houve aumento de 2875 para 3069 no número de municípios com acesso a esgotamento sanitário, representando um acréscimo de 6,8\% (194 municípios) no período. Houve uma expansão do serviço de esgotamento sanitário, e este se deu muito mais pela ampliação da rede coletora nos municípios já atendidos, do que pela incorporação de novos municípios, movimento acompanhado pela melhora da qualidade da rede, com destaque para o aumento do volume de esgoto tratado. 


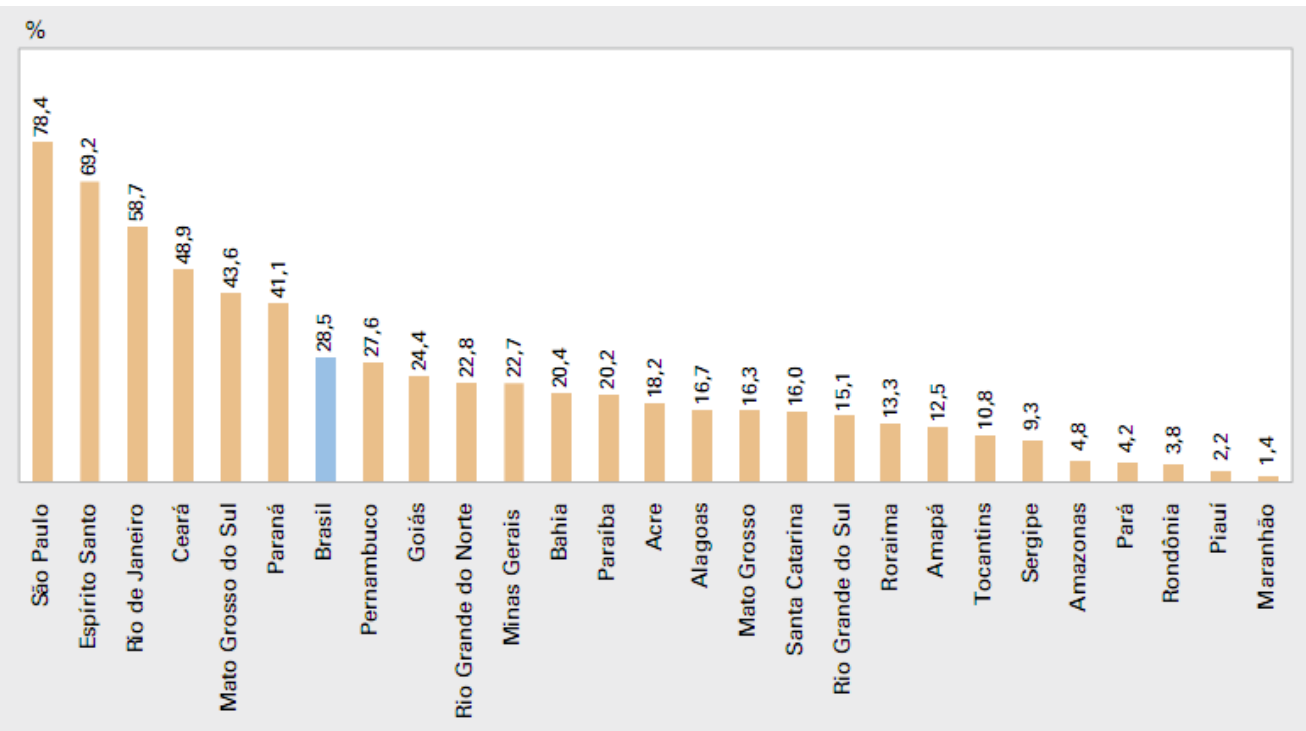

Figura 1: Percentual de municípios com tratamento de esgoto, em ordem decrescente, segundo as Unidades da Federação - 2008. Fonte: IBGE, Diretoria de Pesquisas, Coordenação de População e Indicadores Sociais, Pesquisa Nacional de Saneamento Básico 2008.

De 2000 a 2008, houve uma forte tendência no aumento da população urbana e diminuição da população rural. Em 2008, apenas 15,65\% da população (29.852.986 pessoas) viviam em situação rural, contra $84,35 \%$ em situação urbana (160.879.708 pessoas). Isso implica que a problemática observada com maior intensidade em áreas rurais a respeito de tratamento de esgoto teve uma queda.

Aproximadamente $16 \%$ da população possuía rede coletora de esgotos e/ ou fazia uso de fossas sépticas. Contudo, a grande maioria (41\%) utilizava-se de fossas rudimentares, mais conhecidas como "fossas negras", como solução final para o esgoto doméstico gerado (IBGE, 2004).

Há de se reconhecer que com a redução da população vivendo na zona rural, as contaminações do solo e corpos d'água provenientes de instalações precárias de tratamento de esgoto, como as fossas rudimentares, também atingiram determinada redução.

Entretanto, o que atualmente vem sendo discutido é o destino dos dejetos de animais proveniente das atividades de suinocultura e avicultura, por exemplo. A criação intensiva de suínos, por exemplo, tem sido responsável por grandes problemas ambientais em algumas regiões do Brasil. Isto se deve a alta concentração de matéria orgânica e nutrientes nesta matriz que, quando não corretamente manejados e tratados, podem causar um grande impacto sobre a biota do solo e água (PALHARES, 2003). O grande volume de dejetos gerados, somado aos desperdícios de ração e água de higienização das instalações, se tornou uma importante fonte de poluição, principalmente quando o manejo e destinação final ocorrem de forma inadequada. A suinocultura, sob esse aspecto, apresenta-se como uma atividade 
potencialmente causadora de degradação ambiental, principalmente pelo elevado risco de contaminação do solo (CERETTA, et al., 2003; SIMIONI, 2001) e de cursos d'água (BALDISSERA, 2002; SEGANFREDO, et al., 2004).

\subsection{1 - PROCESSOS BIOLÓGICOS: A DIGESTÃO ANAERÓBIA}

Fundamentalmente, o processo mais empregado para realização do tratamento de esgotos envolve ações metabólicas de microorganismos. Quando ocorre o processo biológico, as reações de respiração microbiana podem ser pela via aeróbia, quando os microrganismos utilizam oxigênio dissolvido (OD) para converter a matéria orgânica biodegradável em dióxido de carbono e água. Quando há ausência de OD, porém com a presença de nitrato (N$\mathrm{NO}_{3}$ ), em uma condição denominada anóxica, este pode ser utilizado em substituição ao OD para a reação de respiração, resultando também, como produtos finais da respiração dióxido de carbono e água e liberação de N-gasoso, em uma reação denominada de desnitrificação. Na ausência de $\mathrm{OD}$ e de $\mathrm{N}-\mathrm{NO}_{3}$, a reação de respiração é anaeróbia e tem como produtos finais dióxidos de carbono e gás metano (ALEM SOBRINHO, 2001).

O processo de digestão anaeróbia, conhecido desde o final do século XIX, se caracteriza pela depuração da matéria orgânica em ambiente livre de oxigênio molecular (Figura 2). Devido à robustez e alta eficiência, a digestão anaeróbia está presente desde em simples fossas sépticas domésticas até em estações completamente automatizadas servindo a grandes regiões metropolitanas. Ressaltam-se as seguintes ações que ocorrem durante o processo de anaerobiose:

- redução substancial dos sólidos voláteis;

- redução significativa dos organismos patogênicos;

- estabilização de substâncias instáveis presentes no esgoto.

Normalmente, a digestão anaeróbia é opção preferida de estabilização, devido ao seu baixo custo operacional. A digestão anaeróbia gera como produtos da estabilização o gás carbônico e o gás metano, incentivando ainda mais esta opção de tratamento devido ao potencial energético gerado. 


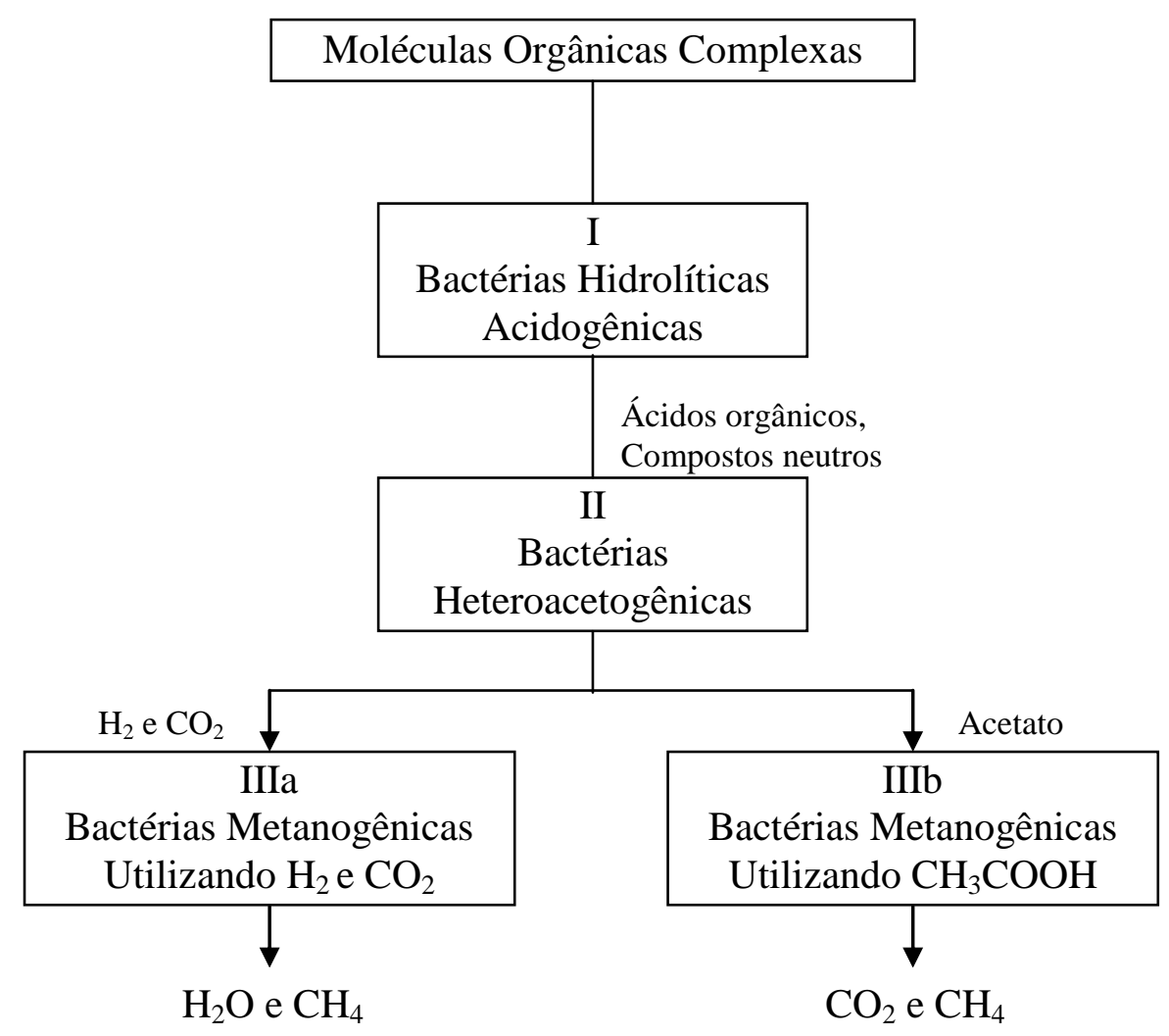

Figura 2 - Esquema da via de degradação anaeróbia da matéria orgânica (FAUSTINO, 2007).

A digestão anaeróbia se apresenta como um processo onde ocorrem múltiplos estágios, por isso sua capacidade de estabilizar diferentes tipos de matéria orgânica. $\mathrm{O}$ processo anaeróbio ocorre basicamente em seis estágios principais (JEYASEELAN, 1997):

1) Hidrólise de biopolímeros orgânicos complexos (proteínas, carboidratos e lipídeos) em monômeros (aminoácidos, açucares e ácidos graxos de cadeia longa) por bactérias hidrolíticas (grupo I) (acidogênicas);

2) Fermentação de aminoácidos e açucares por bactérias hidrolíticas (grupo I);

3) Oxidação anaeróbia de ácidos graxos voláteis e álcoois pelas bactérias heteroacetogênicas (grupo II);

4) Oxidação anaeróbia de produtos intermediários tais como ácidos graxos voláteis pelas bactérias heteroacetogênicas (grupo II);

5) Conversão de hidrogênio a metano pelas bactérias metanogênicas utilizando hidrogênio e dióxido de carbono (grupo IIIa);

6) Conversão de acetato a metano pelas bactérias metanogênicas utilizando acetato (grupo IIIb). 
Em um sistema de tratamento anaeróbio como o biodigestor, coexistem três grupos de bactérias mutuamente dependentes entres si: bactérias acidogênicas hidrolíticas, bactérias acetogênicas e bactérias metanogênicas. Esta população permanece em equilíbrio dinâmico, variando sua concentração de acordo com as condições operacionais de cada sistema biodigestor. Outros organismos encontrados e que podem desempenhar papel fundamental no processo de digestão são as bactérias redutoras de sulfato e as bactérias desnitrificantes (ALEM SOBRINHO, 2001).

\section{2 - BIODIGESTORES: FUNDAMENTAÇÃO E USO}

A recomendação mais usual para o manejo ou tratamento dos dejetos de suínos, por exemplo, tem sido o seu manuseio na forma líquida e armazenamento em esterqueiras ou lagoas para posterior uso em lavouras como fertilizantes. No entanto, estudos como o de (OLIVEIRA, 2000) têm demonstrado que esta conduta, embora proporcione a redução do potencial poluidor dos dejetos, não permite que o resíduo final seja lançado diretamente nos recursos d’água.

Frente esta problemática, a instalação e utilização de biodigestores tem se mostrado como uma alternativa para o tratamento desses dejetos. A biodigestão anaeróbia realizada através de biodigestores para estabilização de diferentes substratos é bastante antiga. No Brasil esta tecnologia teve um forte impulso nas décadas de 70 e 80 caindo posteriormente em descrédito devido, principalmente, a falta de conhecimento e acompanhamento técnico desta tecnologia. Na década de 90, a biodigestão anaeróbia novamente ganhou força, colocando-se como alternativa para agregação de valor ao dejeto além de propiciar a degradação da fração líquida podendo esta ser utilizada como biofertilizante dentro dos preceitos das boas práticas agronômicas (KUNZ, 2004).

Em linhas gerais, o biodigestor consiste em uma câmara fechada onde a biomassa juntamente com o volume de esterco suíno produzido é fermentada anaerobicamente, isto é, sem a presença do ar atmosférico, produzindo biogás e biofertilizante. Recomenda-se em alguns casos que seja aportado à mistura, periodicamente, determinado volume de esterco bovino fresco em água. Isso se deve ao fato deste material ser rico em quantidade e diversidade de microorganismos capazes de promover a degradação anaeróbia, atuando como um meio inoculante de bactérias (NOVAES et al., 2002).

Embora a primeira instalação operacional destinada a produzir gás combustível só tenha surgido na segunda metade do século XIX, o biogás já era conhecido desde há muito 
tempo, pois a produção de gás combustível a partir de resíduos orgânicos não é um processo novo (BALDISSERA et.al, 2002).

O primeiro digestor a batelada, o qual recebe carga total de biomassa e somente é esvaziado após a total degradação da matéria orgânica aportada e produção de biogás, regularmente entrou em funcionamento em Bombaim no ano de 1900 (SEIXAS et al, 1980).

O desenvolvimento e a pesquisa acerca de biodigestores ocorreram com ênfase na Índia, onde foi desenvolvida em 1939, a primeira usina de gás de esterco pelo Instituto Indiano de Pesquisa Agrícola, em Kanpur. De acordo com (NOGUEIRA, 1986), tais pesquisas resultaram na grande difusão da metodologia de biodigestores atuando no tratamento de dejetos de animais, obtenção do biogás e o produto final exercendo a função de biofertilizante.

Conforme menciona (CUNHA, 2007), a produção do biogás e seu emprego como fonte de energia motivou a China a adotar essa tecnologia a partir de 1958. No ano de 1973, com a crise energética, a construção e utilização de biodigestores passou a ser uma opção difundida entre países ricos e países em desenvolvimento. Em nenhum deles, contudo, o uso dessa tecnologia alternativa foi tão acentuada como na China e Índia.

Por isso, os modelos de biodigestores mais difundidos correspondem aos criados por chineses e indianos. No entanto, o modelo canadense também ganhou espaço e por suas particularidades é igualmente empregado.

De modo geral, os biodigestores são compostos por duas partes: um tanque para abrigar e conduzir a digestão da biomassa, e o gasômetro (campânula), para armazenar o biogás. O biodigestor pode funcionar com abastecimento diário de biomassa, ou seja, de modo contínuo, ou de modo intermitente, quando recebe carga de biomassa correspondente à sua carga máxima, retendo-a por tempo determinado até que a digestão esteja completa.

O biodigestor do tipo chinês (Figura 3) é mais rústico, sendo construído exclusivamente de alvenaria e de modo que fique enterrado no solo. O modelo indiano de biodigestor (Figura 4) também possui estrutura subterrânea, mas apresenta sua cúpula feita de ferro ou fibra. Já o modelo do tipo canadense (Figura 5) é construído de forma horizontal, com sua largura em dimensões maiores que a profundidade, caracterizando assim uma maior área de incidência de raios solares, favorecendo o processo de produção do biogás e degradação da matéria orgânica (CUNHA, 2007; CASTANHO, 2008). 


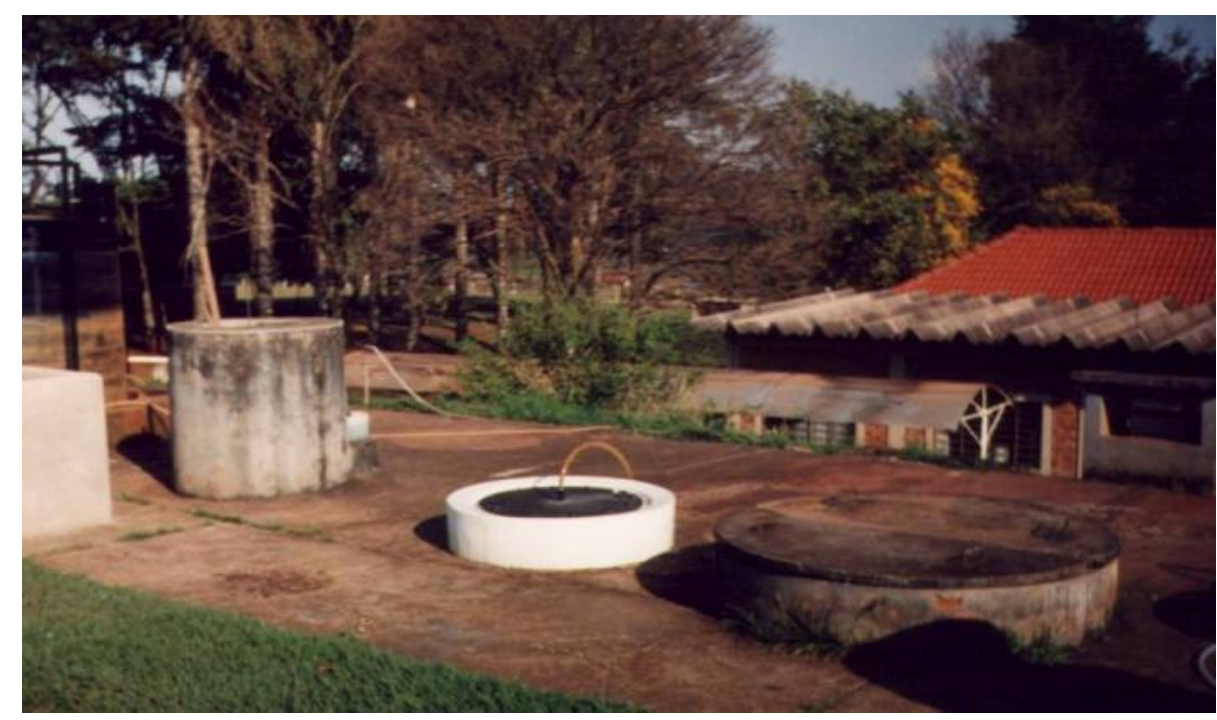

Figura 3: Biodigestor de modelo Chinês

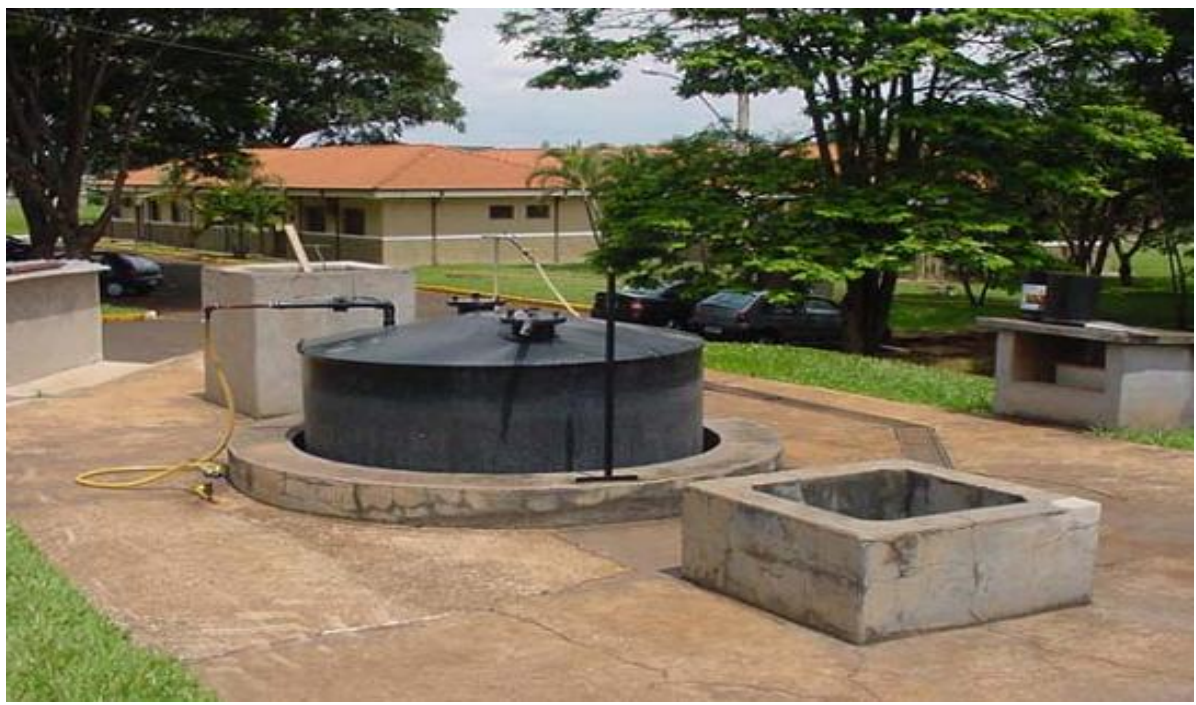

Figura 4: Biodigestor de modelo Indiano

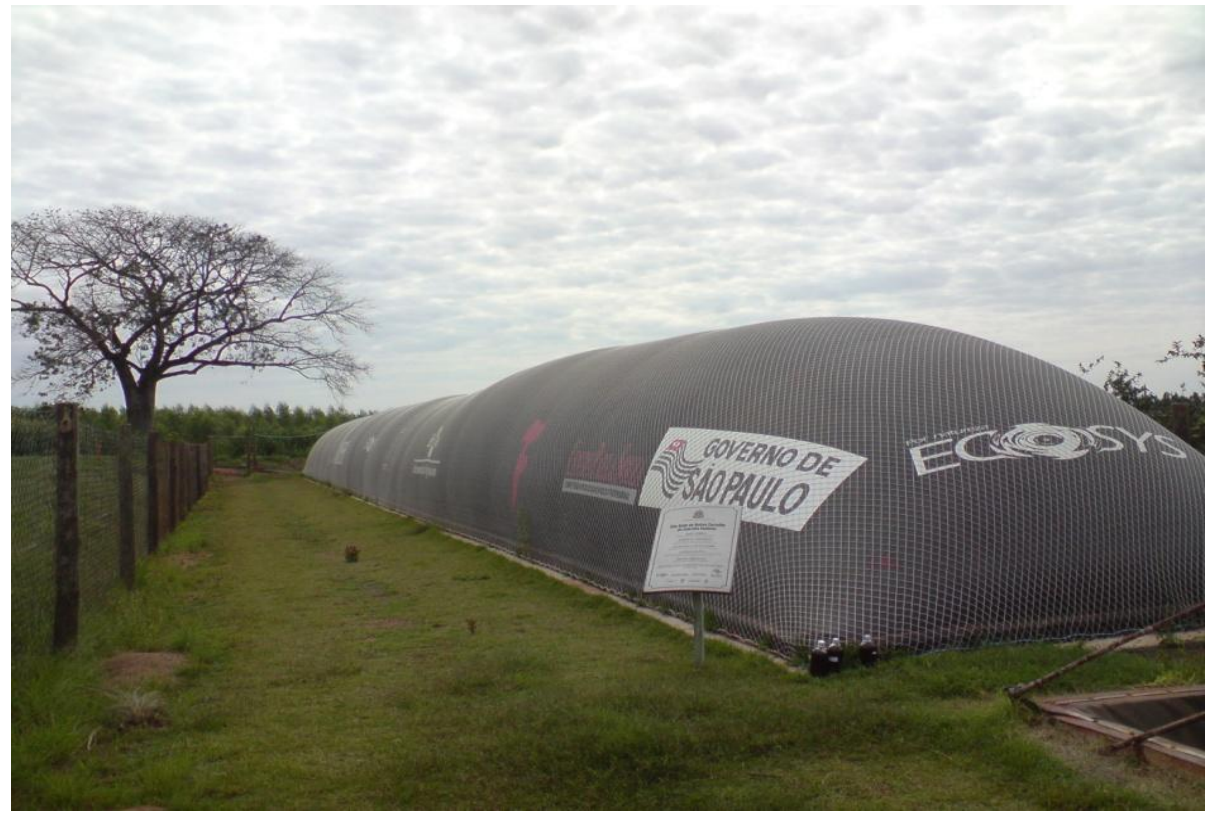

Figura 5: Biodigestor de modelo Canadense 


\section{3 - A QUÍMICA ENVOLVIDA NO COMPARTIMENTO SOLO}

O compartimento "solo", de importância vital para a humanidade, constitui-se como uma matriz de variados e intensos estudos, muitos deles ainda não elucidados. Isso se deve pelo fato de que o solo se mostra um tanto quanto complexo, pois inúmeros aspectos são envolvidos e devem ser levados em consideração quando suas características e propriedades são discutidas, já que todas elas atuam em conjunto nas diferentes funções que o solo como um todo desempenha. Estudar o solo implica atentar para sua organização (constituintes minerais e orgânicos), considerar peculiaridades morfológicas e estruturais, dimensões e modo de organização, incluindo também os espaços vazios (poros) e também chamada fase gasosa do solo (MARTIN-NETO et al, 2004).

$\mathrm{O}$ estudo freqüentemente conduzido com o solo se baseia na caracterização e conhecimento do chamado perfil do solo. Esses perfis se diferenciam através dos chamados "horizontes", segundo uma organização de um corte vertical do solo, sendo os superiores mais ricos em matéria orgânica (horizonte $\mathrm{O}$ ) e os inferiores mais ricos sobretudo em minerais (horizontes E, B e C). Pode-se distinguir tais horizontes pela cor, textura, estrutura e comportamento (FAUSTINO, 2007).

De acordo com (ROCHA et al, 2009), em relação à proporcionalidade, os compartimentos do solo variam de solo para solo, condições climáticas, presença de vegetação e tipo de manejo. De modo geral, um solo considerado em ótimas condições para o crescimento vegetal se caracteriza volumetricamente por $50 \%$ de fase sólida (sendo $45 \%$ de origem mineral e $5 \%$ de orgânica), $25 \%$ de fase líquida e $25 \%$ de fase gasosa. (MALAVOLTA, 1976). A Figura 6 mostra um exemplo dos compartimentos do solo.

A essas fases, soma-se a biota, a qual é de extrema importância para a ocorrência de determinadas reações, atuando também na constituição de um ambiente adequado para a vida vegetal. 


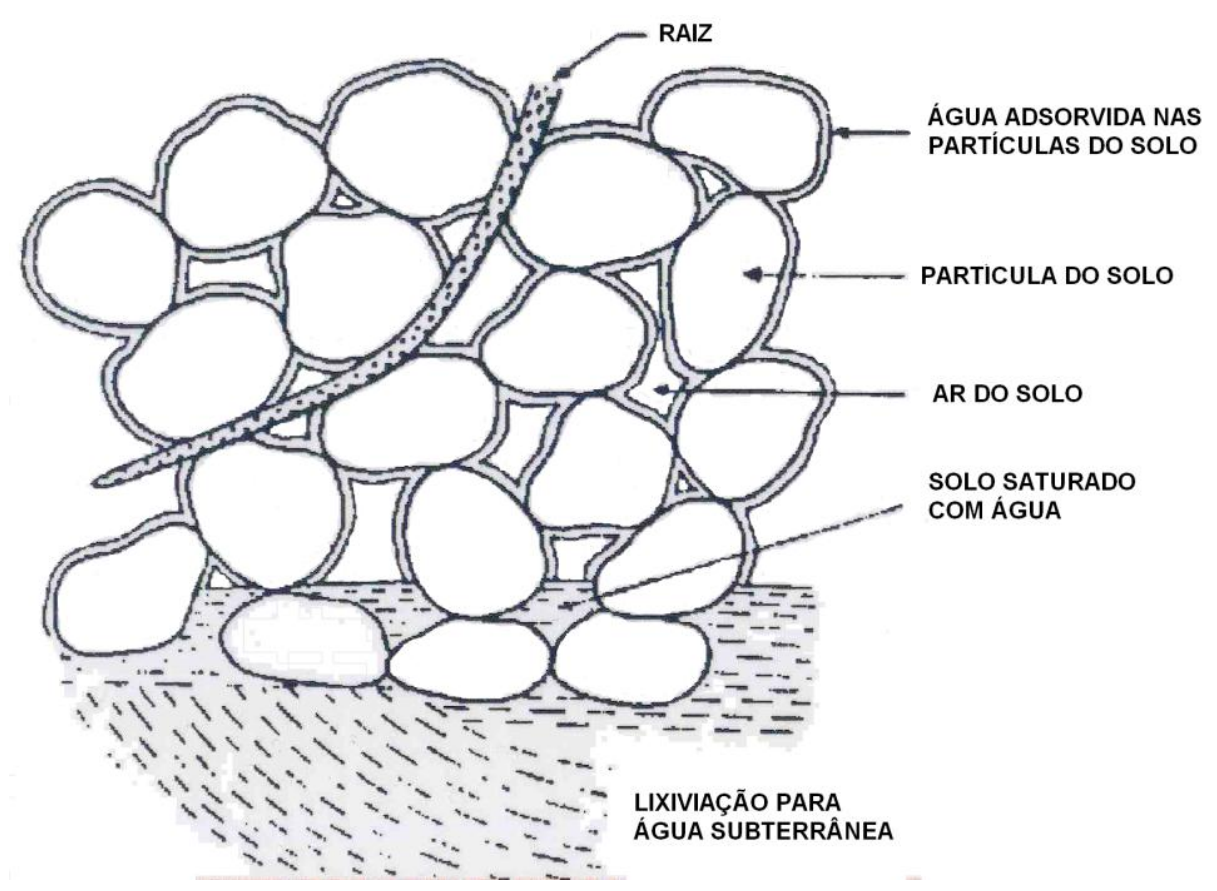

Figura 6: Representação de um solo (adaptado de MANAHAN, 1994)

Sendo assim, pode-se descrever sucintamente cada um dos compartimentos pode ser sucintamente assim descrito:

- fração mineral:

É resultante da degradação física das rochas, assumindo composição química semelhante à da rocha-mãe da qual originou-se. Nesta fração, encontram-se a argila, o silte e a areia.

-fração orgânica:

Caracteriza-se pela porção do solo constituída por substâncias provenientes de plantas e animais mortos.

-fração líquida:

Também conhecida como "solução do solo", corresponde à "solução de eletrólitos do solo". Representa importante papel no transporte e fornecimento de nutrientes para as plantas, além de propiciar a realização de inúmeros processos químicos e biológicos que ocorrem no solo.

Esta fração tem origem com a água das chuvas, que se infiltram pelos espaços existentes entre as partículas do solo, conforme sua permeabilidade. Quando a permeabilidade é pequena, há maior probabilidade da ocorrência de processos erosivos, já que por não infiltrar-se adequadamente, a água segue para vales e rios, carregando sedimentos e também elementos nutritivos.

- fase gasosa: 
Corresponde à dinâmica de fluxos gasosos estabelecidos entre o ar atmosférico e o solo, por meio da respiração de raízes e microorganismos, bem como decomposição da matéria orgânica (ROCHA, et.al. 2009).

A proporção de água e de ar no solo pode variar de maneira bastante acentuada e muito rapidamente, estando associada principalmente aos tamanhos e quantidades de poros existentes, disponibilidade de água e drenagem do terreno. A fase sólida, ao contrário, é mais constante (MELFI e MONTES, 2001). Essas condições influenciam diretamente as propriedades físico-químicas do solo.

As propriedades químicas do solo constituem uma enorme gama, principalmente àquelas relacionadas aos aspectos de fertilidade e nutrição de plantas. A troca iônica é uma delas, e está relacionada à presença de cargas superficiais, sendo entendida como um processo reversível, pelo qual, íons retidos na superfície são substituídos por quantidades equivalentes de outros íons, estejam estes em solução ou ligados a uma outra fase sólida, em contato com a primeira.

Os mais importantes cátions trocáveis presentes nos solos são o $\mathrm{Ca}^{2+}, \mathrm{Mg}^{2+}, \mathrm{H}^{+}, \mathrm{K}^{+}$, $\mathrm{Na}^{+}$e $\mathrm{NH}_{4}{ }^{+}$. Entre os ânions, destacam-se o $\mathrm{SO}_{4}{ }^{2-}, \mathrm{Cl}^{-}, \mathrm{NO}_{3}{ }^{-}, \mathrm{H}_{2} \mathrm{PO}_{4}{ }^{-}, \mathrm{HPO}_{4}{ }^{2-}, \mathrm{HCO}_{3}{ }^{-}$e os ânions dos ácidos húmicos.

A capacidade de troca catiônica (CTC) também se destaca frente às propriedades químicas do solo. Ela define a habilidade do solo em reter e adsorver cátions e se relaciona com a presença de cargas negativas na superfície das partículas coloidais (argilominerais, óxidos e oxihidróxidos de $\mathrm{Fe}$ e $\mathrm{Al}$ e compostos orgânicos - húmus). A CTC depende da textura do solo e, mais particularmente, do teor de argila e matéria orgânica, pois tanto a argila quanto a matéria orgânica apresentam grandes superfícies específicas, e portanto são materiais bastante reativos, daí possuírem CTC elevada. Destas duas, a matéria orgânica, normalmente presente em menor quantidade, apresenta CTC cerca de cinco vezes àquela das argilas, podendo também apresentar grande variação em função da concentração dos grupos carboxílicos - COOH (MELFI e MONTES, 2001).

$\mathrm{O} \mathrm{pH}$, sendo outra propriedade química essencial, é responsável por determinar sob que forma os elementos químicos estarão nas soluções que percolam o solo. Em função do pH do solo e do pKa dos elementos, pode-se prever sua existência sob uma forma catiônica (ou aniônica), sob forma de hidróxidos ou ainda sob forma de sais, possivelmente definindo-se a mobilidade dos elementos em determinado solo, caso a solubilidade dos produtos formados seja conhecida. 


\section{4 - MATÉRIA ORGÂNICA DO SOLO}

A matéria orgânica do solo (MOS) apresenta-se como um importante constituinte, sendo um componente fundamental influenciando a qualidade dos sistemas agrícolas em razão de seu conteúdo e sua qualidade serem os mais importantes fatores que mantêm a fertilidade dos solos e a sustentabilidade dos agroecossistemas (MARTIN-NETO et al., 2004; REEVES, 1997).

Segundo (STEVENSON, 1994), a matéria orgânica do solo é proveniente da mistura de compostos em vários estágios de decomposição, que resultam da degradação biológica de resíduos de plantas e animais, e da atividade sintética de microrganismos, denominado húmus. Este material complexo pode ser dividido operacionalmente, em substâncias húmicas (ácidos húmicos, ácidos fúlvicos e humina) e não húmicas (proteínas, aminoácidos, polissacarídeos, ácidos orgânicos de baixa massa molar ceras e outros).

As substâncias não húmicas abrangem compostos de grupamentos bem conhecidos da química orgânica e suas características físicas e químicas são bem elucidadas. De modo geral, correspondem aos compostos facilmente degradados por microrganismos, tendo, normalmente, tempo curto de vida nos solos e sedimentos. Por sua vez, as substâncias húmicas $(\mathrm{SH})$ são os maiores constituintes da fração orgânica dos solos, sendo que não apresentam estrutura nem massa molar definidas.

Ao referir-se à matéria orgânica, cabe destacar que se trata de um constituinte do solo que pode representar até menos de $1 \%$ do total em massa, em muitos solos, mas que pelas características químicas, envolvimento com as atividades biológicas, importância para a fertilidade do solo e nutrição das plantas, papel na agregação das partículas do solo, e reatividade com os demais constituintes endógenos e até exógenos ao solo (como pesticidas e elementos tóxicos) tem papel muito relevante. Nos solos a MO pode apresentar-se em quantidades muito variadas, desde $0,5 \%$ (nos solos desérticos) e 95\% (solos turfosos). No Brasil, a maior parte dos solos apresentam teores de MO entre 1 e 3\% (STEVENSON, 1994; LUCHESE et al, 2002).

A MOS desempenha diversas funções no solo, entre elas, citam-se:

- função biológica: regula as atividades da microflora e dos organismos da microfauna; -função nutritiva: atua como fonte de nutrientes para o desenvolvimento das plantas, retendo e fornecendo tanto os macronutrientes $(\mathrm{N}, \mathrm{P}, \mathrm{K}, \mathrm{Ca}, \mathrm{Mg}$ e $\mathrm{S})$ quanto micronutrientes 
(Zn, $\mathrm{Fe}, \mathrm{Mn}$ e $\mathrm{Cu})$ de suas necessidades, impedindo a perda por lixiviação e arraste dos fertilizantes químicos;

- função física e físico-química: melhora a capacidade de retenção de água, drenagem, aeração e conserva a estrutura do solo. É um dos grandes responsáveis pela CTC e a capacidade tampão do solo. Participa também no processo de decomposição de agentes tóxicos, formando compostos complexos com metais pesados e pesticidas e auxilia na retenção de calor influenciando na germinação de sementes e desenvolvimento das raízes (STEVENSON, 1994).

A Figura 7 ilustra o papel exercido pela matéria orgânica do solo (MOS) e pelos microrganismos na qualidade estrutural do solo, promovendo a adesão das partículas com produção de substâncias cimentantes, como os polissacarídeos de alta viscosidade e as substâncias húmicas (CANELLAS et al, 2008; MOREIRA; SIQUEIRA, 2006).

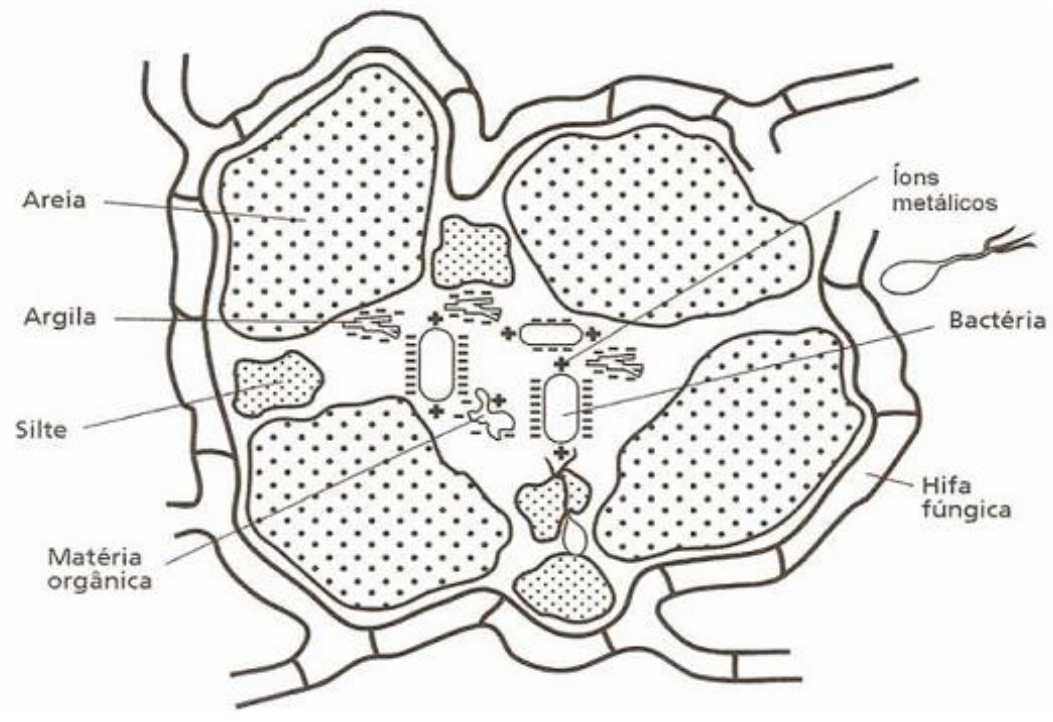

Figura 7: Estrutura de um agregado de solo com destaque ao papel cimentante e agregador da matéria orgânica e dos microrganismos em interação com partículas de areia e argila. (MOREIRA e SIQUEIRA, 2008).

\subsection{1 - SUBSTÂNCIAS HÚMICAS}

Atribui-se às substâncias húmicas $(\mathrm{SH})$ a característica de serem os componentes mais recalcitrantes da MOS e são formadas por uma mistura heterogênea de compostos orgânicos naturais com elevada massa molar, na qual cada fração de substâncias húmicas constitui-se de uma série de moléculas de tamanhos diferenciados, sem que suas configurações estruturais sejam semelhantes nem que seus grupos reativos apresentem-se necessariamente nas mesmas posições. Estas substâncias são formadas a partir do processo denominado "humificação", o 
qual se destaca por possibilitar a alteração de estruturas químicas da MOS por meio da degradação de resíduos orgânicos via lixiviação, trituração e catabolismo. Variáveis como temperatura, regime de água do solo, $\mathrm{pH}$ e nutrientes livres controlam esse processo, que proporciona um aumento nos grupos C-carboxílicos, $\mathrm{C}$-aromáticos e $\mathrm{C}$-alquil, principalmente fenólicos e a diminuição de grupos O-alquil (ZECH et al.,1997).

As SH diferem-se de outros biopolímeros do húmus, como carboidratos e proteínas por não apresentarem estrutura molecular e propriedades físicas definidas e serem recalcitrantes, isto é, são capazes de permanecer por um longo período no solo. A presença de vários grupos cromóforos em sua estrutura resulta em absorção de energia em uma ampla faixa do espectro eletromagnético, o que lhes confere cores variando de marron-clara a escura. Atuam significantemente na formação de agregados, no controle da acidez do solo e no ciclo de elementos nutrientes. Essas substâncias são amorfas, escuras, com grande conteúdo de grupos orgânicos, tais como, carboxílicos, fenólicos, enólicos, alcoólicos, quinonas entre outros e quimicamente complexas (STEVENSON, 1994; SAAB, 1999; MARTIN-NETO et al., 2004).

Há uma classificação das substâncias húmicas a qual leva em consideração sua solubilidade em meio aquoso, segundo (STEVENSON, 1994):

- ácidos húmicos: fração solúvel em meio alcalino, precipitando após acidificação;

- ácidos fúlvicos: fração solúvel em todas as condições de pH;

- humina: fração insolúvel em qualquer intervalo de pH.

Destas três frações, os ácidos húmicos são mais suscetíveis às mudanças estruturais decorrentes de práticas de manejo do solo e dos processos de degradação da MOS (TATZBER et al., 2008).

Ressalta-se que essa classificação não leva em consideração as propriedades inerentes a essas substâncias, atendendo apenas às características de solubilidade em meio aquoso das mesmas.

Quatro características estruturais descrevem a reatividade das $\mathrm{SH}$, de acordo com (SPOSITO, 1989; REZENDE, 1999):

- Carga Macromolecular: possui caráter aniônico, cujos efeitos refletem na conformação molecular e na reatividade dos grupos funcionais. 
- Hidrofilicidade: reflete-se na tendência que têm as SH de formarem ligações de hidrogênio com as moléculas de água do meio, solvatando, dessa forma, grupos funcionais como $\mathrm{COOH}$ e $\mathrm{OH}$.

- Labilidade estrutural: devido à capacidade de formarem associações intermoleculares e de mudanças conformacionais em resposta as mudanças de $\mathrm{pH}$, condições redox, ligações químicas e concentração iônica.

- Polifuncionalidade: presença de vários grupos funcionais, com reatividades diferentes, representativos de uma mistura heterogênea de polímeros que interagem entre si.

Existem, basicamente, duas propostas em discussão para a definição de uma estrutura química para os ácidos húmicos. Em polêmica e em freqüente discussão, há estudiosos que defendem, diferentemente, duas propostas: o modelo macromolecular e o modelo supramolecular (SWIFT, 1999; PICCOLO, 2001; BURDON, 2001).

\subsubsection{1 - O MODELO MACROMOLECULAR DAS SUBSTÂNCIAS HÚMICAS}

Este modelo fundamenta-se na semelhança dos ácidos húmicos às macromoléculas biológicas como proteínas, polissacarídeos, ácidos nucléicos e lignina. SCHULTEN e SCHNITZER (1993), utilizando-se de técnicas analíticas, tais como pirólise, espectroscopia, degradação oxidativa e microscopia eletrônica sugeriram a estrutura esquemática e macromolecular para os ácidos húmicos, apresentada na Figura 8. Nesta estrutura, o ácido húmico contém longas cadeias alifáticas, grupos $\mathrm{OH}$ fenólicos livres e ligados, nitrogênio e oxigênio atuando como ligação dos grupos $\mathrm{COOH}$ localizados de diferentes formas nos anéis aromáticos. 


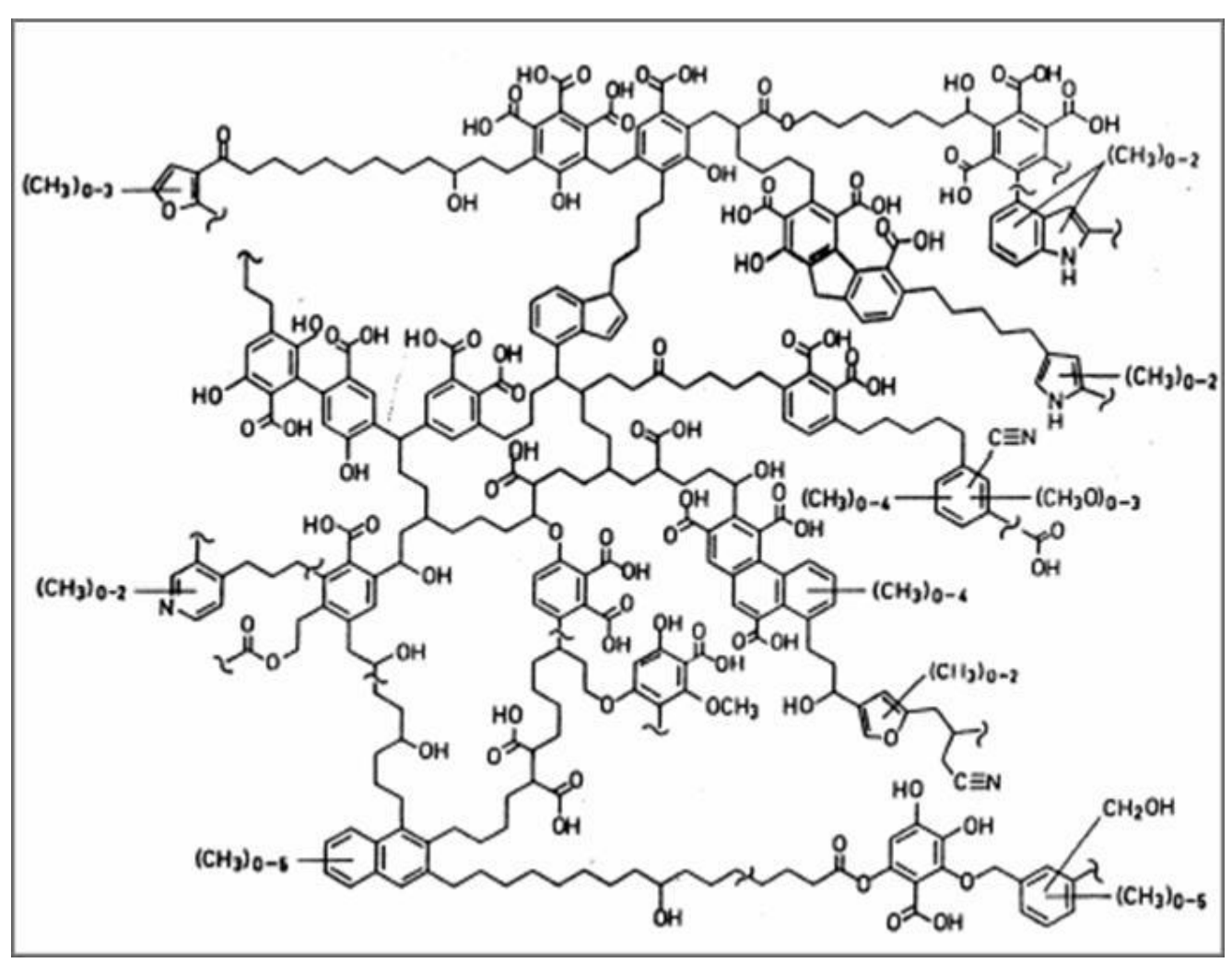

Figura 8: Modelo de estrutura macromolecular para ácido húmico proposto por SCHULTEN e SCHNITZER (1993).

Seguindo os estudos que pretendem elucidar melhor a estrutura dos ácidos húmicos, SCHULTEN e SCHNITZER (1997) propuseram a existência de espaços vazios (Figura 9) de diferentes tamanhos, os quais poderiam funcionar como sítios onde seriam alojados outros compostos orgânicos, hidrofílicos ou hidrofóbicos, como carboidratos e materiais proteináceos, lipídeos, além de pesticidas e outros poluentes. 


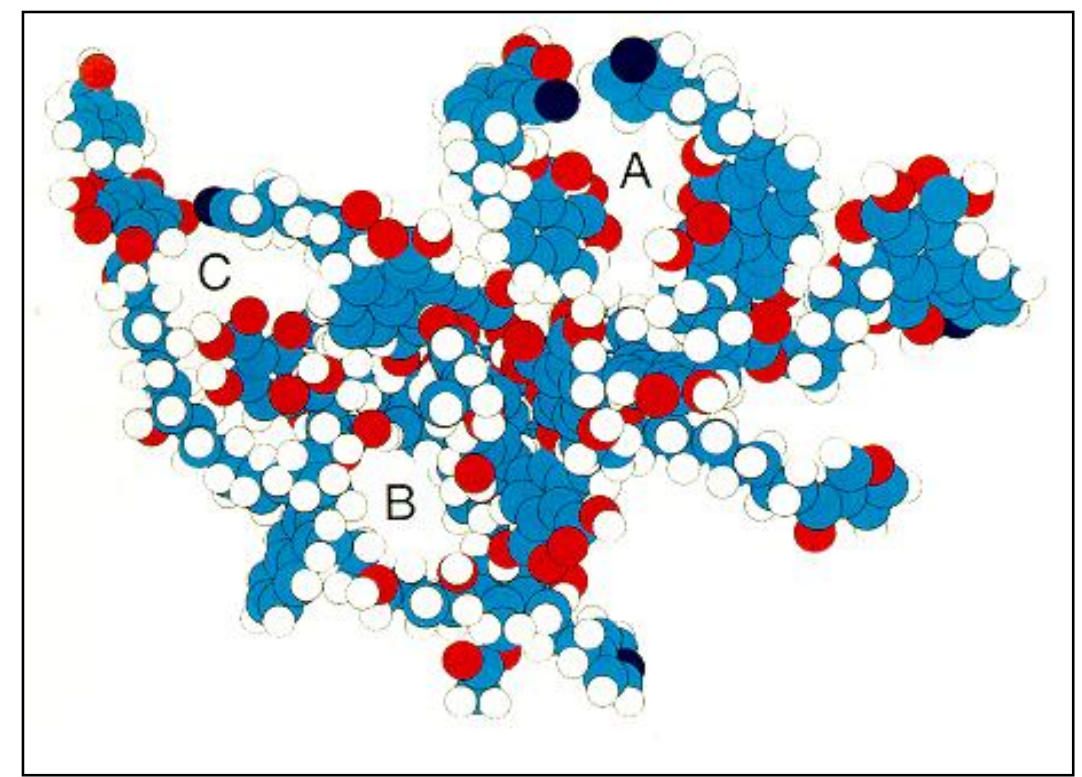

Figura 9: Modelo tridimensional de ácido húmico proposto por SCHULTEN e SCHNITZER (1997). As esferas coloridas correspondem aos elementos Carbono : azul; Oxigênio: vermelho; Nitrogênio: preto e Hidrogênio: branco. As letras A, B e C indicam os espaços vazios presentes nas estruturas das $\mathrm{SH}$.

Neste modelo, SENESI et al. (1996) mostra em seus resultados que a estrutura do ácido húmico é expandida conforme há aumento do valor de $\mathrm{pH}$ do meio. $\mathrm{O}$ aspecto retraído do ácido húmico em meio ácido se deve às ligações de hidrogênio formadas e interações hidrofóbicas. Em meio neutro a alcalino, tem-se uma estrutura aberta devido à repulsão eletrostática de grupamentos carboxílicos e fenólicos desprotonados. A Figura 10 apresenta tais conformações:

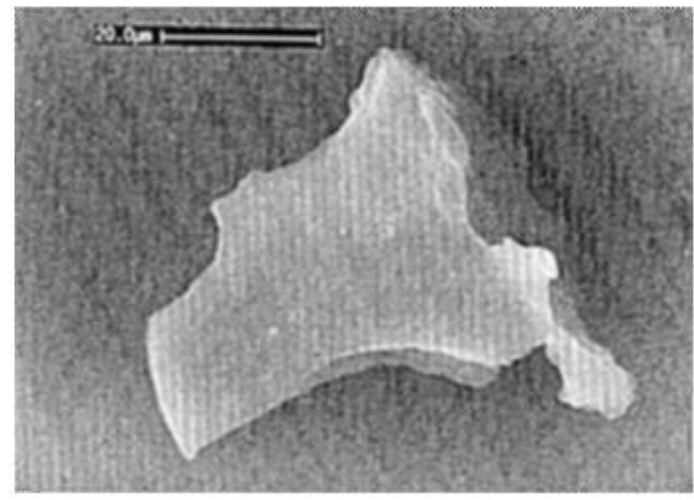

(a)

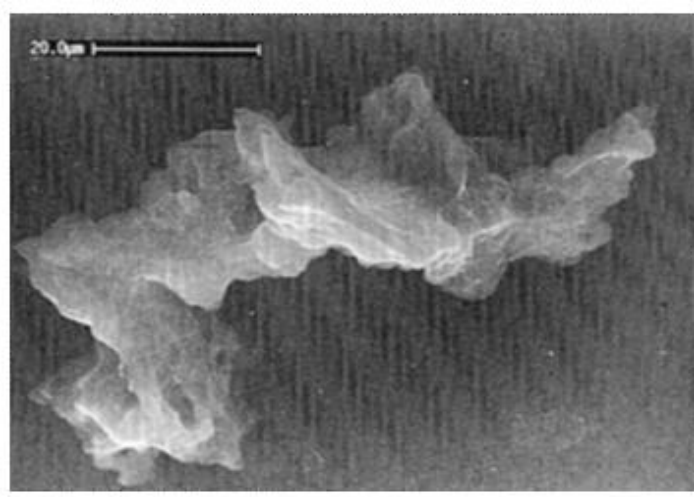

(b)

Figura 10: Microscopia Eletrônica de Varredura apresentando as conformações estruturais de um ácido húmico extraído de solo, onde (a) representa a conformação retraída em meio ácido (pH 3) e (b) refere-se à conformação expandida em meio neutro (pH 7) (SENESI et al. 1996). 


\subsubsection{2 - O MODELO SUPRAMOLECULAR DAS SUBSTÂNCIAS HÚMICAS}

Segundo PICCOLO (2001), as SH seriam moléculas pequenas e heterogêneas, de várias origens e auto-organizadas em conformações supramoleculares, isto é, unidas por forças intermoleculares, que podem ser ligações de hidrogênio, interações doador-aceptor (tipo ácido-base de Lewis) ou interações iônicas. As superestruturas húmicas seriam estabilizadas por forças fracas, tais como interações hidrofóbicas do tipo van der Waals e ligações de hidrogênio, estas últimas sendo mais importante quanto menor o valor de $\mathrm{pH}$. Estas interações determinariam a estrutura conformacional nas supramoléculas de SH.

Sendo assim, considerando este modelo, os ácidos fúlvicos seriam associações de pequenas moléculas hidrofílicas dispersas em solução devido à repulsão eletrostática das cargas negativas provenientes da dissociação dos grupos ácidos, como por exemplo, os carboxílicos, a qualquer valor de pH. Os ácidos húmicos são constituídos por associações de estruturas predominantemente hidrofóbicas (cadeias polimetilênicas, ácidos graxos e esteróides), que são estabilizadas em meio ácido por forças dispersivas hidrofóbicas (van der Waals, $\pi-\pi$, e ligações $\mathrm{CH}-\pi$ ). Os ácidos húmicos crescem gradualmente em tamanho com o decréscimo do pH até a sua precipitação. De acordo com PICCOLO (2001), a influência da concentração hidrogeniônica ocorre por meio da protonação da molécula em meio ácido e consequiente aumento das ligações de hidrogênio intermoleculares. Resultados obtidos por (SIMPSON, 2002; SIMPSON et al., 2002) corroboram com os de (PICCOLO, 2001), reforçando a idéia deste modelo. Seus ensaios demonstraram que as substâncias húmicas extraídas de solos são formadas por uma mistura de substâncias agregadas de peso molecular em torno de 2000 Da e propuseram um esquema (Figura 11) para sugerir como agregados na presença de cátions metálicos comumente encontrados no ambiente poderiam ser formados a partir das principais estruturas identificadas nas substâncias húmicas. 


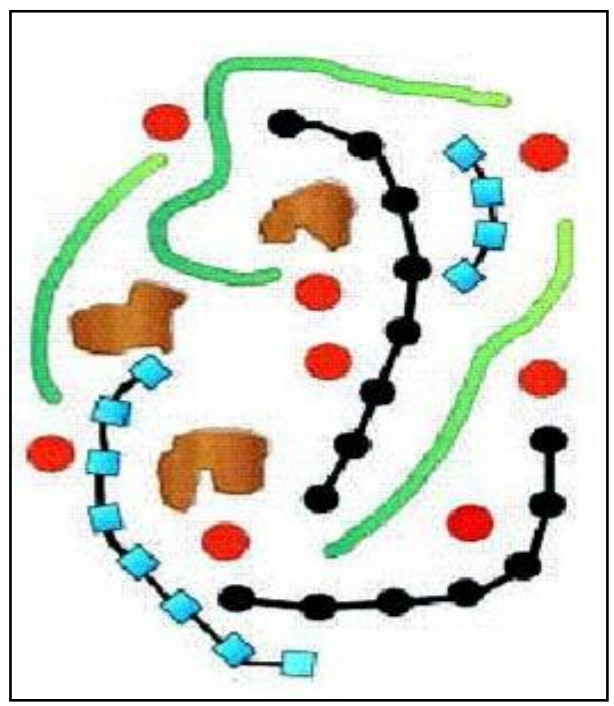

Figura 11: Esquema de estrutura das SH proposto por SIMPSON et al. (2002), unidades vermelhas: cátions metálicos; unidades pretas: polissacarídeos; unidades azuis: polipeptídios; unidades verdes: cadeias alifáticas e unidades marrons: fragmentos aromáticos.

Utilizando ferramentas computacionais e dados experimentais, (DIALLO et al., 2003) excluíram os modelos que estabelecem que as SH sejam macromoléculas com elevada massa molar ou uma mistura de compostos orgânicos complexos e heterogêneos e observaram que as estruturas existentes possuem as características necessárias para sustentar o modelo supramolecular.

Estudos recentes conduzidos por PÉDROT et al. (2010) enfatizam que a estrutura dos ácidos húmicos são dinâmicas e sensíveis às condições ambientais do meio. Tais condições influenciam não apenas o tamanho e conformação dos ácidos húmicos como também afetam a distribuição e a mobilidade de elementos-traço que são comumente fortemente ligados às substâncias húmicas.

A força iônica do meio e a variação no valor de $\mathrm{pH}$ influenciam significativamente o comportamento das substâncias húmicas.

Baseado em cálculos provenientes de modelos feitos por (TOMBACZ et al., 1990), a repulsão entre as partículas das substâncias húmicas decresce com a diminuição do $\mathrm{pH}$ e aumento na concentração iônica do meio, ambas favorecendo o aumento na formação de agregados.

PÉDROT et al. (2010) descreve, ademais, que o pH representa papel de maior relevância na distribuição de tamanhos das substâncias húmicas, envolvendo a ocorrência combinada de pequenas moléculas e associações supramoleculares. 
Pode-se dizer que a maior dificuldade encontrada quando se pretende estabelecer a definição de um modelo estrutural para as SHs que englobe estrutura, composição, tamanho e reatividade, de modo geral, é a heterogeneidade, já que as $\mathrm{SH}$ existem em caráter bastante diversificado nos variados ecossistemas naturais aquáticos e terrestres.

\section{5 - APLICAÇÃO DE RESÍDUOS NO SOLO}

Os trabalhos científicos sobre a utilização de esgotos tratados em práticas agrícolas têm demonstrado que sua disposição no solo adiciona uma série de substâncias que podem alterar suas propriedades físicas, químicas, físico-químicas e biológicas, afetando em geral, positivamente o desenvolvimento das plantas (MELO et al., 1994; SOUSA et al., 2001; FONSECA et al., 2005; HUSSAR et al., 2005; NGOLE et al., 2006; FONSECA et al., 2007).

Os resíduos de esgotos são constituídos essencialmente por matéria orgânica, de acordo com o tipo de tratamento ao qual foi submetido. Isso significa que sua disposição no solo permite a incorporação de uma quantidade apreciável de matéria orgânica (MO) nos horizontes superficiais do solo.

A adição de resíduos orgânicos provoca importantes alterações nos atributos físicos, químicos e físico-quimicos do solo, em decorrência do aumento do conteúdo de MO. Vários autores mostraram os efeitos positivos que a adição de matéria orgânica provoca no estado de agregação das partículas, na porosidade, na densidade, na capacidade de retenção e infiltração de água, na temperatura, na capacidade de troca catiônica (CTC), no $\mathrm{pH}$ e na fertilidade do solo (METZGER e YARON, 1987; MARCIANO et al., 1999, FONSECA et al., 2005).

\subsection{1 - EFLUENTE DE ESGOTO TRATADO: APLICAÇÃO AGRÍCOLA E POSSÍVEIS IMPACTOS}

A principal vantagem na utilização de efluentes no solo reside na recuperação de um recurso de grande importância para a agricultura - a água; além disso, os constituintes desses efluentes são produtos que podem aumentar a fertilidade dos solos por conter nutrientes essenciais às plantas. Por outro lado, melhoram também a aptidão agrícola dos solos, devido à MO que lhe é adicionada, com a conseqüente formação de húmus.

O uso do EET na agricultura tende a reduzir a descarga deste material nos corpos d'água. Estudos nessa linha vem se tornando cada vez mais freqüentes, visto que com o crescimento urbano-populacional a quantidade de água disponível, seja para abastecimento público ou para uso em atividades agrícolas têm decrescido continuamente ao longo dos anos, 
sendo fundamental a conscientização da população quanto à necessidade do reuso e a importância (FIRME, 2007).

O uso de efluentes provenientes do tratamento de esgotos, na agricultura, é uma prática comum em muitos países (SAAD et al., 2006; FONSECA et al., 2007). Em países de clima tropical como o Brasil, esse tipo de prática apresenta aspectos positivos em função da temperatura a qual o solo é exposto, o que favorece uma intensa atividade intempérica, disponibilizando nutrientes ao meio.

Vários países, localizados tanto em regiões áridas como úmidas, tais como Israel, Arábia Saudita e Austrália, têm mostrado a viabilidade da utilização, de forma sustentável, dos efluentes de esgoto tratados na irrigação (PESCOD, 1992). No Brasil, essa prática ainda é recente, requer maiores informações técnico-científicas e necessita de estudos de longo prazo (FONSECA, 2001). Entretanto, estudos já realizados no país apontam para a viabilidade na utilização de efluentes de esgoto tratado na agricultura (MONTES et al., 2006; MOTA et al., 2006; SANTOS, 2004; FONSECA et al., 2007; GLOAGÜEN et al., 2007; HERPIN et al., 2007; SANTOS et al., 2009).

Importantes alterações nos atributos físicos, químicos e físico-quimicos do solo, em decorrência do aumento do conteúdo de MO, são observados quando há adição de resíduos orgânicos, como efluentes. Vários autores mostraram os efeitos positivos que a adição de matéria orgânica provoca no estado de agregação das partículas, na porosidade, na densidade, na capacidade de retenção e infiltração de água, na temperatura, na capacidade de troca catiônica (CTC), no pH e na fertilidade do solo (METZGER e YARON, 1987; MARCIANO et al., 1999, FONSECA et al., 2005).

Alterações nas propriedades físico-químicas do solo afetam, de forma acentuada, sua funcionalidade, pois alteram a circulação das soluções no interior do solo. O pH é uma propriedade química essencial do solo, visto que a concentração hidrogeniônica desempenha importante papel no comportamento dos elementos químicos no solo e também o comportamento dos seres vivos (fauna e flora). De uma maneira geral, a adição de resíduos orgânicos tende a proporcionar um aumento no valor do $\mathrm{pH}$ e também nas cargas negativas do solo (BATAGLIA et al., 1983), sendo que a existência de cargas elétricas condiciona a reatividade físico-química dos constituintes do solo com os íons que se encontram na solução do solo ou nos outros constituintes minerais, polímeros orgânicos ou minerais, que possuam cargas na superfície (MELFI e MONTES, 2001).

O valor de pH de águas residuárias usadas em irrigação, contudo, não afeta significativamente o pH do solo, devido ao seu poder tampão. Dessa forma, não é de se esperar efeito direto do 
efluente no $\mathrm{pH}$ do solo, mesmo com a ocorrência de $\mathrm{HCO}_{3}{ }^{-}$(uma das formas presentes de alcalinidade) nas águas residuárias. No entanto, existe a possibilidade dessa alcalinidade

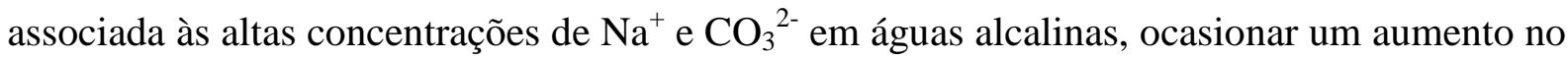
valor de pH do solo (BOUWER e IDELOVITCH, 1987).

O aumento da condutividade elétrica (CE) do solo mediante a irrigação com efluente é comum em sistemas agrícolas, pastagens e florestas, mais pronunciadamente na camada superficial do solo. Esse aumento de salinidade mais evidente na superfície do solo se dá, possivelmente, por dois fatores: evaporação da superfície do solo, levando ao acúmulo de sais; exposição do subsolo à contínua lixiviação (FONSECA, 2007).

Sabendo-se das vantagens, mas também com a possibilidade de ocorrência de efeitos negativos, torna-se imprescindível que a qualidade, a quantidade e a freqüência da aplicação do efluente no solo sejam estudadas com maior ênfase. O impedimento hidráulico e a diminuição da taxa de difusão de $\mathrm{O}_{2}$ nos solos irrigados com água residuária são dependentes da qualidade do efluente (quantidade de sólidos suspensos e dissolvidos) (ORON, et al, 1999). Apesar dos sólidos suspensos de origem orgânica presentes no efluente (flocos de bactérias materiais fibrosos, algas, etc.) terem tamanhos reduzidos, quando associados a ação de bactérias e mediante a produção de polissacarídeos e outros compostos orgânicos, podem ocasionar entupimento biológico da superfície do solo. Além disso, uma dose elevada de aplicação de nitrogênio possibilita uma maior lixiviação, podendo levar à contaminação de lençóis freáticos, principalmente em solos arenosos. Geralmente, pelo fato do efluente ser salino, o excesso de sais na zona radicular (independentemente das espécies iônicas presentes) prejudica a produtividade das plantas. (FAUSTINO et. al, 2007).

\subsection{2 - BREVE DESCRIÇÃO DA LEGISLAÇÃO PERTINENTE À APLICAÇÃO DE EFLUENTES NO SOLO}

Com bastante intensidade têm sido questionada a reutilização de efluentes provenientes do tratamento de esgotos industriais e sanitário visando aplicação agrícola. Ao longo dos anos, a legislação brasileira aborda temas neste aspecto, na tentativa de cada vez mais definir padrões e orientar quanto às melhores condições e implicações do reuso de efluentes tratados no solo. Entretanto nota-se a necessidade de se explorar mais as diversas características que os efluentes podem ter, levando em consideração as várias particularidades de cada tratamento e materiais tratados. 
Em relação à temática ambiental, pode-se citar o surgimento do Decreto $\mathrm{N}^{\circ} 8.468$, de 1976, atualizado com redação dada pelo Decreto 54.487, de 26/06/09, que dispõe sobre a prevenção e o controle da poluição do meio ambiente, de maneira generalizada.

No que tange ao lançamento de efluentes, cita-se a resolução CONAMA 357, de 2005 , que dispõe sobre a classificação dos corpos de água e diretrizes ambientais para o seu enquadramento, bem como estabelece as condições e padrões de lançamento de efluentes. Esta resolução deverá ter os padrões de lançamento atualizados e complementados, conforme prorrogação de prazo para tal ação descrita na Res. CONAMA 410 de 2009.

Já a Resolução CONAMA 375, de 2006, define critérios e procedimentos, para o uso agrícola de lodos de esgoto gerados em estações de tratamento de esgoto sanitário e seus produtos derivados, e dá outras providências.

Sobre o solo, propriamente dito, existem: a Lei № 13.577, de 2009, e a CONAMA 420 de 2009. A primeira tem como objetivo garantir o uso sustentável do solo, protegendo-o de contaminações e prevenindo alterações nas suas características e funções, por meio de: - medidas para proteção da qualidade do solo e das águas subterrâneas;

-medidas preventivas à geração de áreas contaminadas; -procedimentos para identificação de áreas contaminadas; -garantia à saúde e à segurança da população exposta à contaminação; -promoção da remediação de áreas contaminadas e das águas subterrâneas por elas afetadas; -incentivo à reutilização de áreas remediadas; -promoção da articulação entre as instituições; -garantia à informação e à participação da população afetada nas decisões relacionadas com as áreas contaminadas.

Tais medidas e procedimentos são de responsabilidade da CETESB (Companhia Ambiental do Estado de São Paulo).

Já a Resolução CONAMA 420 de 2009 Dispõe sobre critérios e valores orientadores de qualidade do solo quanto à presença de substâncias químicas e estabelece diretrizes para o gerenciamento ambiental de áreas contaminadas por essas substâncias em decorrência de atividades antrópicas.

Entretanto, embora já sejam abordadas noções do ponto de vista de prevenção de contaminações, remediação de áreas já contaminadas e parâmetros de padrões aceitáveis de substâncias no solo, até mesmo para uso de lodo de esgoto doméstico e industrial, ainda é escassa a existência de normas específicas para aplicação de diferentes tipos de efluentes e produtos na agricultura. Há até o momento apenas documentos um pouco mais específicos 
publicados pela CETESB como o de Orientação para Apresentação de Projeto Visando a Aplicação de Água de Reuso Proveniente de Estação de Tratamento de Esgoto Doméstico na Agricultura. No fim do ano de 2006, foi publicada também pela CETESB a Norma Técnica P4.231, a qual descreve critérios e procedimentos para a aplicação agrícola da vinhaça no solo (CETESB, 2006).

\section{6 - DETERMINAÇÃO DA MATÉRIA ORGÂNICA DO SOLO}

Entre as determinações que visam analisar o teor de carbono proveniente da MOS, pode-se citar a análise do teor de Carbono Orgânico Total (TOC), métodos que empregam a gravimetria e a termogravimetria, além da Análise Elementar e da determinação do teor de carbono via úmida (metodologia Walkley-Black), as quais foram empregadas no presente estudo.

Resultados obtidos por (SEGNINI et al., 2008) ressaltam que nenhum dos métodos de determinação é inviável, do ponto de vista de confiabilidade de resultados. É evidenciada, entretanto, a necessidade de uma visão crítica sobre as limitações e vantagens de cada método na determinação de carbono em solos.

\subsection{1 - ANÁLISE ELEMENTAR}

Grande parte das características de uma amostra de MOS são obtidas a partir de sua composição elementar. Os primeiros experimentos para determinação da composição elementar das substâncias húmicas $(\mathrm{SH})$ foram realizados por Sprengel e Berzelius entre os anos de 1826 e 1845 (STEVENSON, 1994). Segundo eles, as SH constituem-se, mais abundantemente, de carbono e oxigênio, seguido de nitrogênio, enxofre e hidrogênio. Variados são os métodos empregados para a determinação desses elementos, dentre eles os métodos químicos. Os elementos carbono e hidrogênio, por exemplo, podem ser determinados por combustão completa a seco; nitrogênio pelos métodos de Dumas ou de Kjeldahl; oxigênio por pirólise redutiva e enxofre por combustão (HUFFMAN JR. e STUBER, 1985).

Entretanto, a utilização de analisadores elementares automáticos muito contribuiu nesse sentido, permitindo a realização de análises rápidas e confiáveis (JIMENEZ e LADHA, 1993). O funcionamento desses equipamentos se baseia na oxidação da amostra em alta temperatura $\left(1000^{\circ} \mathrm{C}\right)$, após os gases resultantes são separados por uma coluna cromatográfica 
e detectados, geralmente, por condutividade térmica (SKOOG et al., 2002). Por esta técnica, analisam-se simultaneamente os elementos C, H, N e S presentes em amostras orgânicas e inorgânicas, podendo elas estar na forma líquida, gasosa ou sólida. O princípio operacional consiste em três etapas: a amostra, a qual é mantida em cápsula de estanho, é oxidada produzindo uma mistura de gases $\left(\mathrm{N}_{2}, \mathrm{CO}_{2}, \mathrm{H}_{2} \mathrm{O}\right.$ e $\left.\mathrm{SO}_{2}\right)$ que são separados em uma coluna cromatográfica e quantificados por meio de um detector de termocondutividade, gerando um sinal elétrico proporcional à quantidade do gás. Com o equipamento, são detectados na seqüência os gases $\mathrm{N}_{2}, \mathrm{CO}_{2}, \mathrm{H}_{2} \mathrm{O}$ e $\mathrm{SO}_{2}$, podendo ser convertidos em $\% \mathrm{~N}, \% \mathrm{C}, \% \mathrm{H}, \% \mathrm{~S}$ e cinzas. A determinação do elemento oxigênio é calculado por diferença, caso a quantidade de cinzas da amostra seja baixa ou descontada do total, conforme mostra a Equação 1:

$$
\% \mathrm{O}=[(100-(\mathrm{C}+\mathrm{N}+\mathrm{H}+\mathrm{S}+\text { cinzas })] \% \quad \text { Eq. } 1
$$

Através dessa metodologia, é possível que sejam calculados estoques de carbono de amostras de solos, a razão $\mathrm{C} / \mathrm{N}$, pela qual se estabelece a disponibilidade do nitrogênio para as plantas e microorganismos, além de estimativas do grau de humificação da MOS. Trata-se de uma técnica que facilita a caracterização de uma substância, não apenas pela rapidez, como pelas informações que podem ser obtidas. Contudo, a quantidade de amostra utilizada nessas análises pode influenciar na representatividade do resultado obtido, visto que na maioria dos equipamentos de análises elementares, geralmente $1 \mathrm{mg}$ de amostra é utilizada, e para amostras heterogêneas como o solo, esse método pode apresentar a desvantagem de não apresentar boa repetibilidade atingindo um elevado desvio padrão na média das réplicas investigadas (SEGNINI, 2007). Ressalta-se que é uma técnica limpa, diferentemente da metodologia citada posteriormente - Walkley-Black - , a qual gera um volume considerável de resíduos de alta toxidez. No entanto, o custo de cada determinação bem como a manutenção do próprio equipamento são elevados.

\subsection{2 - MÉTODO WALKLEY-BLACK}

Um método clássico para determinação de MOS (WALKLEY e BLACK, 1934) e que foi adaptado por JACKSON (1982), se baseia na oxidação do carbono orgânico do solo por íons dicromato, em meio fortemente ácido. Em amostras que requeiram maior precisão, a determinação da quantidade de íons $\mathrm{Cr}^{3+}$ reduzidos é feita indiretamente, por titulação dos íons dicromato em excesso com íons $\mathrm{Fe}^{2+}$. Alternativamente, pode-se determinar diretamente a quantidade de íons $\mathrm{Cr}^{3+}$ por colorimetria, medindo-se a intensidade da cor esverdeada produzida por esses íons em solução. A determinação por colorimetria, normalmente usada 
em rotina, requer a elaboração de uma curva-padrão de calibração. Nos dois casos, a oxidação da MOS é expressa pela reação (Equação 2):

$$
2 \mathrm{Cr}_{2} \mathrm{O}_{7}^{2-}{ }_{(\mathrm{aq})}+3 \mathrm{C}_{(\mathrm{s})}^{0}+16 \mathrm{H}^{+}{ }_{(\mathrm{aq})} \rightarrow 4 \mathrm{Cr}^{3+}{ }_{(\mathrm{aq})}+3 \mathrm{CO}_{2(\mathrm{~g})}+8 \mathrm{H}_{2} \mathrm{O}_{(\mathrm{l})} \quad \text { Eq. } 2
$$

Nessa reação (Equação 2), considera-se o dicromato reduzido equivalente ao carbono orgânico existente na amostra de solo, e o excesso de dicromato é titulado com íons $\mathrm{Fe}^{2+}$ obtidos a partir de uma solução padronizada de sulfato ferroso amoniacal, conforme mostra a reação abaixo (Equação 3):

$$
\mathrm{Cr}_{2} \mathrm{O}_{7}{ }_{(\mathrm{aq})}^{2-}+6 \mathrm{Fe}^{2+}{ }_{(\mathrm{aq})}+14 \mathrm{H}^{+}{ }_{(\mathrm{aq})} \rightarrow 2 \mathrm{Cr}^{3+}{ }_{(\mathrm{aq})}+6 \mathrm{Fe}^{3+}{ }_{(\mathrm{aq})}+7 \mathrm{H}_{2} \mathrm{O}_{(\mathrm{l})} \quad \text { Eq.3 }
$$

A quantidade de carbono orgânico é obtida pela diferença entre a quantidade de $\mathrm{Fe}^{2+}$ gasta na titulação quando o $\mathrm{Cr}^{6+}$ foi adicionado, e aquela gasta na titulação do dicromato que restou $\left(\mathrm{Cr}^{3+}\right)$ após a oxidação do carbono da amostra, assumindo que todo o carbono da MOS está no estado de oxidação zero (CANTARELLA et al.,2001). A fórmula comumente empregada na determinação da matéria orgânica do solo é:

$\operatorname{MOS}\left(\mathrm{g} \cdot \mathrm{kg}^{-1}\right)=\mathrm{C} \times 1,724$, sendo $(1,724)$ o fator de van Bemmelen, face ao conceito de que o teor de carbono da MOS é igual a 58\%. Entretanto, esta é somente uma estimativa, já que este fator varia conforme determinadas características do solo e humificação da MOS (CONCEIÇÃO et al., 1999).

\section{7 - MÉTODOS ESPECTROSCÓPICOS}

O emprego de técnicas espectroscópicas para a caracterização da MOS têm sido bastante úteis. Técnicas como espectroscopia de infravermelho com transformada de Fourier (FTIR), fluorescência de luz uv-visível e fluorescência induzida por laser (FIL) fornecem informações sobre os grupos funcionais mais freqüentemente presentes na MOS, avaliando o grau de humificação deste material. Sabe-se, contudo, que estudos nessa linha com solos tropicais ainda são reduzidos (MARTIN-NETO et al., 1991; BAYER et al., 1997; MILORI et al., 2002; GONZÁLES-PEREZ et al., 2004).

Cada uma dessas técnicas fornece determinadas informações, e seus resultados complementam-se entre si, evidenciando tendências e peculiaridades das amostras estudadas. 


\subsection{1 - ESPECTROSCOPIA NA REGIÃO DO INFRAVERMELHO MÉDIO COM TRANSFORMADA DE FOURIER (FTIR)}

A radiação infravermelha corresponde à parte do espectro eletromagnético entre as regiões do visível e das microondas. A espectroscopia no infravermelho é uma das ferramentas mais úteis para o químico na identificação de compostos orgânicos e inorgânicos, pois, com exceção de poucos compostos homonucleares tais como as moléculas de $\mathrm{O}_{2}, \mathrm{~N}_{2}$ e $\mathrm{Cl}_{2}$, todas as espécies moleculares absorvem radiação infravermelha (SKOOG et al., 2002). A região do infravermelho de maior utilidade para os químicos orgânicos está localizada entre 4000 e $400 \mathrm{~cm}^{-1}$. Há também uma região de 14290-4000 $\mathrm{cm}^{-1}$, chamada de infravermelho próximo e outra em $700-200 \mathrm{~cm}^{-1}$, denominada infravermelho distante.

A interação da radiação infravermelha com uma molécula envolve a interação de um componente oscilante do campo elétrico da radiação com o momento dipolo oscilante da molécula. Assim, para as moléculas absorverem radiação infravermelha como energia de excitação vibracional é necessário haver mudança em seu momento de dipolo, e quando há esta modificação, os compostos absorvem energia em certas regiões do espectro. As moléculas diatômicas homonucleares não apresentam mudança em seu momento dipolo, conseqüentemente não possuem absorção no infravermelho.

A absorção de radiação infravermelha pela molécula resulta em movimentos rotacionais e vibracionais dos grupos moleculares e de suas ligações químicas. As vibrações podem ocorrer tanto na forma de estiramento, na qual os átomos permanecem no mesmo eixo de ligação, variando-se o comprimento da ligação, como também na forma de deformação angular, onde as posições dos átomos mudam em relação ao eixo de ligação original. Vibrações típicas de um grupo de átomos são ilustradas na Figura 12.
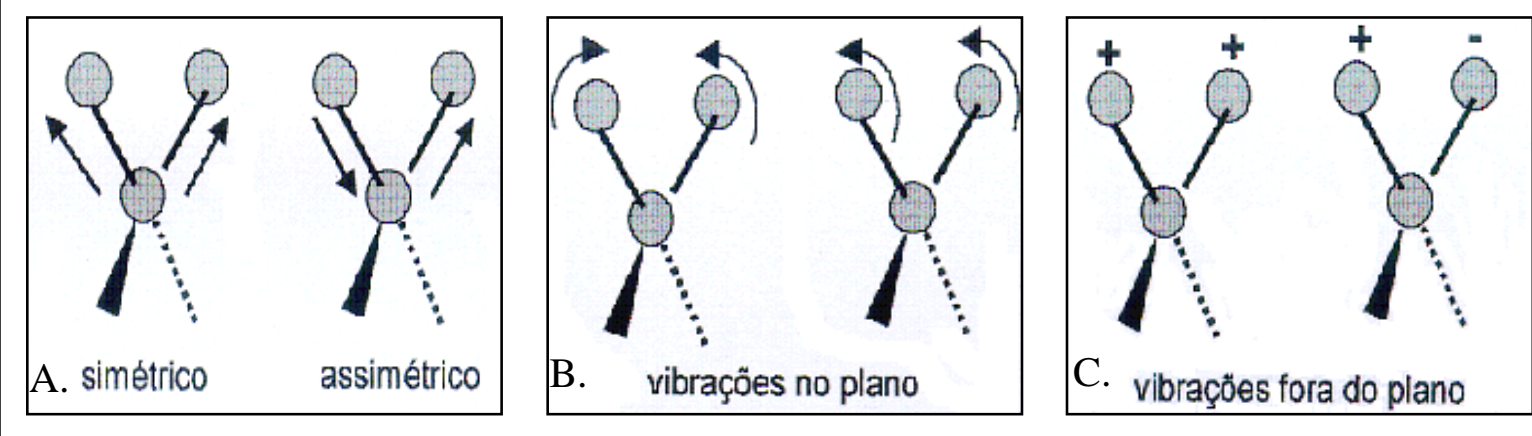

Figura 12 - Vibrações típicas de átomos. A. Vibrações de estiramento; B. e C. Vibrações de deformação angular. Os sinais $+\mathrm{e}-$ significam vibrações perpendiculares ao plano do papel (STUART, 1996) 
A espectroscopia vibracional na região do infravermelho é muito utilizada para identificar grupos funcionais presentes em compostos orgânicos, sendo de grande importância na avaliação da taxa de degradação de compostos de lodo de esgoto (GRUBE et al., 2006) e também na caracterização das substâncias húmicas presentes no solo (STEVENSON, 1994).

Ressalta-se ainda, que a técnica de FTIR é uma ferramenta bastante útil para observar variações estruturais nas SH em decorrência das mudanças ocorridas por conta do manejo do solo (SENESI et al., 2009)

As informações obtidas na identificação de grupos funcionais como hidróxidos, carboxílicos, carboxilatos, polissacarídeos, alifáticos, aminas, entre outros, auxiliam a descrever a natureza dos ácidos húmicos das mais diferentes origens.

A Figura 13 mostra um espectro típico de FTIR de uma amostra de ácido húmico:

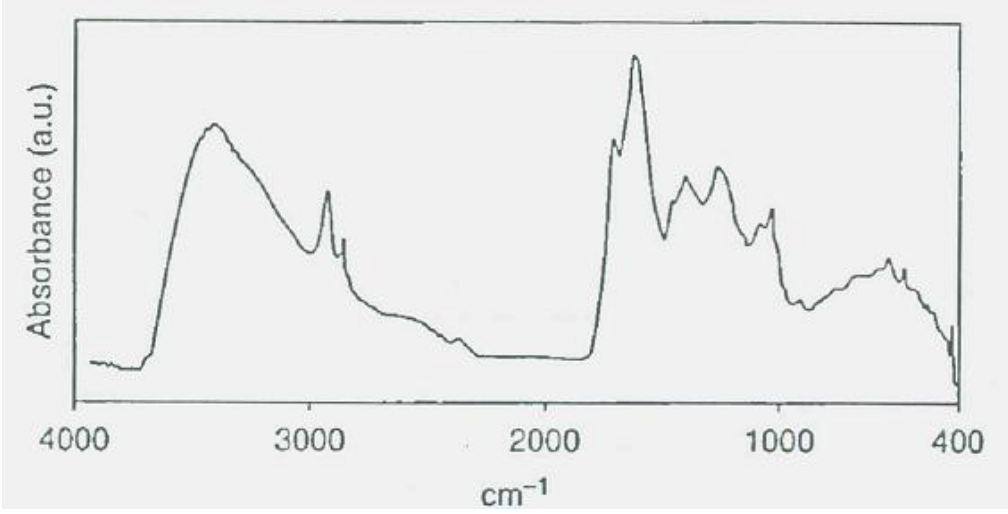

Figura 13: Espectro típico de ácido húmico. (MARTIN-NETO et al., 2009).

A espectrometria com transformações de Fourier (FTIR), que se desenvolveu muito nos últimos anos, tem várias vantagens sobre os instrumentos de dispersão. Como não se usam monocromadores, a totalidade da faixa de radiação passa simultaneamente pela amostra com enorme ganho de tempo. Isto permite resoluções extremamente altas $\left(\leq 0,001 \mathrm{~cm}^{-1}\right)$. Além disto, o resultado de várias varreduras é combinado para diminuir os ruídos, gerando espectros com satisfatória relação sinal/ ruído utilizando-se pouca amostra (SILVERSTEIN, 2000).

Na Tabela 1 são apresentadas algumas bandas típicas das substâncias húmicas. 
Tabela 1 - Bandas no infravermelho do ácido húmico descritas por NIEMEYER et al., (1992)

\begin{tabular}{|c|c|}
\hline $\operatorname{Região}\left(\mathrm{cm}^{-1}\right)$ & Origem \\
\hline 3380 & $\begin{array}{l}\text { Estiramento } \mathrm{OH} \text { do grupo fenólico (contribuição de } \mathrm{OH} \text { alifático, } \mathrm{H}_{2} \mathrm{O} \text { e } \\
\text { possivelmente } \mathrm{NH} \text { ) }\end{array}$ \\
\hline 3030 & Estiramento $\mathrm{CH}$ aromático \\
\hline 2930 & Estiramento $\mathrm{CH}$ assimétrico \\
\hline 2840 & Estiramento CH simétrico \\
\hline 2600 & Estiramento $\mathrm{OH}$ de $\mathrm{H}$-ligado a $-\mathrm{COOH}$ \\
\hline 1720 & Estiramento $-\mathrm{C}=\mathrm{O}$ de $-\mathrm{COOH}$ \\
\hline 1610 & Estiramento $\mathrm{C}=\mathrm{C}$ aromático e/ou estiramento $-\mathrm{COO}^{-}$assimétrico \\
\hline $1520-1525$ & Estiramento $\mathrm{C}=\mathrm{C}$ aromático, deformação $\mathrm{N}-\mathrm{H}$ e estiramento $\mathrm{C}=\mathrm{N}$ de amidas \\
\hline 1450 & Deformação $-\mathrm{CH}$ de $-\mathrm{CH}_{3}$ e dobramento $-\mathrm{CH}$ de $-\mathrm{CH}_{2}$ \\
\hline 1350 & Estiramento - $\mathrm{COO}$ simétrico e/ou dobramento $-\mathrm{CH}$ de alifáticos \\
\hline 1270 & Estiramento $-\mathrm{C}-\mathrm{O}$ de fenólico \\
\hline 1225 & Estiramento $-\mathrm{C}-\mathrm{O}$ e deformação $\mathrm{OH}$ de $-\mathrm{COOH}$ \\
\hline 1170 & Estiramento -C-OH de alifáticos $\mathrm{OH}$ \\
\hline 1050 e 1040 & $\begin{array}{l}\text { Estiramento } \mathrm{C}-\mathrm{O} \text { de polissacarídeos ou derivados de polissacarídeos e } \mathrm{Si}-\mathrm{O} \text { de } \\
\text { impurezas silicatadas }\end{array}$ \\
\hline 830 & Vibração CH fora do plano. Impurezas argilosas \\
\hline 775 & Vibração CH fora do plano \\
\hline
\end{tabular}

\subsection{2 - ESPECTROSCOPIA NA REGIÃO DO INFRAVERMELHO PRÓXIMO (NIRS)}

Consistindo no mesmo princípio que o FTIR, mas utilizando radiação eletromagnética na faixa de 10000 a $4000 \mathrm{~cm}^{-1}$, o espectro obtido por NIRS constitui-se de bandas fracas de acoplamentos e combinações das bandas de vibração de C-H, N-H e O-H que ocorrem na região do infravermelho médio (GERZABEK et al., 2006). Por essa razão, no que diz respeito à interpretação e elucidação de estruturas moleculares, a NIRS é pouco utilizada (WESTAD et al., 2008). 
Como mencionado, o espectro obtido por NIRS apresenta menos informação que o obtido por FTIR. Contudo, MADARI et al. (2005) destacam que componentes inorgânicos como a sílica, que são predominantes no solo e dificultam a identificação de bandas características de compostos orgânicos do solo, absorvem na região do infravermelho médio e não absorvem na região do infravermelho próximo.

A técnica de NIRS também apresenta elevada razão sinal-ruído, alta passagem energética pelos cabos de fibra óptica e disponibilidade de caminhos ópticos de diversos tamanhos (WORKMAN, 1998).

O uso de NIRS para estudos quantitativos de características e propriedades dos solos é relativamente recente (desde 1995) e têm se mostrado atraente (MITTELMANN et al., 2005; MADARI et al., 2006). Além de resultados satisfatórios, cabe ressaltar que esta técnica empregada a amostras de solos, apresenta vantagens do ponto de vista da facilidade na execução das análises: diferentemente da FTIR, NIRS utiliza o solo bruto para as determinações, as quais são rápidas, a amostra não requer tratamento prévio, apenas requer ser peneirada e homogeneizada (FERRARESI, 2010).

$\mathrm{Na}$ Tabela 2 encontram-se descritos os principais grupos funcionais caracterizados pelas bandas de absorção das vibrações de estiramento. 
Tabela 2: Bandas de absorção das vibrações de estiramento dos principais grupos funcionais no espectro de infravermelho próximo $\left(\mathrm{cm}^{-1}\right)$. Adaptada de: Workman, 1998.

\begin{tabular}{|c|c|c|c|c|}
\hline Estrutura & Ligação & $1^{*}$ harmônica & $2^{x}$ harmônica & $3^{x}$ harmônica \\
\hline $\mathrm{ArCH}$ (aromáticos) & $\mathrm{C}-\mathrm{H}$ & $8748-8424$ & $8748-8424$ & $11668-11235$ \\
\hline $\mathrm{CH}=\mathrm{CH}$ (metileno) & $\mathrm{C}-\mathrm{H}$ & $8064-8019$ & $8064-8019$ & $10752-10695$ \\
\hline $\mathrm{CH}_{3}$ (metil) & $\mathrm{C}-\mathrm{H}$ & $8223-8196$ & $8223-8196$ & $10964-10928$ \\
\hline $\mathrm{CH}_{3}$ (metil) & $\begin{array}{c}\text { C-H } \\
\text { combinaçato }\end{array}$ & $7423-7315$ & $7423-7315$ & $9900-9756$ \\
\hline R-OH (ál coois) & $\mathrm{O}-\mathrm{H}$ & $7092-6872$ & $10638-10309$ & $*$ \\
\hline $\mathrm{ArOH}$ (fenóis) & $\mathrm{O}-\mathrm{H}$ & $7037-6802$ & $10559-10204$ & $*$ \\
\hline HOH (água) & $\mathrm{O}-\mathrm{H}$ & $6944-6734$ & $10416 .-10101$ & * \\
\hline Amido & $\mathrm{O}-\mathrm{H}$ & 6891 & 10341 & $*$ \\
\hline Uréia & $\mathrm{N}-\mathrm{H}$ & 6849 & 10277 & * \\
\hline $\mathrm{CONH}_{2}$ (amidas primárias) & $\mathrm{N}-\mathrm{H}$ & $6835-6738$ & $10256-10111$ & $*$ \\
\hline CONHR (amidas secundárias) & $\mathrm{N}-\mathrm{H}$ & 6793 & 10193 & $*$ \\
\hline Celulose & $\mathrm{O}-\mathrm{H}$ & 6711 & 10070 & $*$ \\
\hline Uréia & $\mathrm{N}-\mathrm{H}$ & 6711 & 10070 & * \\
\hline $\mathrm{ArNH}_{2}$ (aminas aromáticas) & $\mathrm{N}-\mathrm{H}$ & 6697 & 10050 & $*$ \\
\hline $\mathrm{NH}$ (aminas em geral) & $\mathrm{N}-\mathrm{H}$ & 6666 & 10000 & $*$ \\
\hline Proteinas & $\mathrm{N}-\mathrm{H}$ & 6618 & 9930 & $*$ \\
\hline Uréia & $\mathrm{N}-\mathrm{H}$ & 6578 & 9871 & $*$ \\
\hline $\mathrm{RNH}_{2}$ (aminas primárias) & $\begin{array}{c}\mathrm{N}-\mathrm{H} \\
\text { combinaçáo }\end{array}$ & * & 9803 & $*$ \\
\hline Amido & $\begin{array}{c}\text { O-H } \\
\text { combinaçåo }\end{array}$ & $*$ & 9737 & $*$ \\
\hline CONH (amidas primárias) & $\begin{array}{c}\mathrm{N}-\mathrm{H} \\
\text { combinação }\end{array}$ & $*$ & 9551 & $*$ \\
\hline - $\mathrm{CH} 2$ (metileno) & $\begin{array}{c}\mathrm{C}-\mathrm{H} \\
\text { combinaça }\end{array}$ & $*$ & 9259 & $*$ \\
\hline
\end{tabular}

\subsection{3 - ESPECTROSCOPIA DE FLUORESCÊNCIA EM SOLUÇÃO}

Descreve-se luminescência como sendo a emissão de luz por uma substância ao ser submetida a algum tipo de estímulo. A luminescência é formalmente divida em duas categorias, fluorescência e fosforescência, dependendo da natureza do estado excitado. $\mathrm{O}$ processo de luminescência de uma molécula está diretamente relacionado com os processos de absorção e dissipação de energia da mesma. A energia absorvida é dependente da diferença de energia entre o estado fundamental e o estado excitado. 
Quando a energia absorvida pela molécula não é suficiente para sua ionização ou dissociação, ela permanecerá no estado excitado por um determinado tempo, chamado tempo de vida do estado excitado. Logo em seguida, ela emite energia na forma de calor e/ ou luz. Essa luz emitida por esse processo é o que chamamos de luminescência. Dependendo do tempo de vida do estado excitado o processo é denominado fluorescência ou fosforescência (Figura 14). Estados excitados com tempos de vida curtos $\left(10^{-7}-10^{-9} \mathrm{~s}\right)$, no qual envolvem transições singleto-singleto, levam a processos chamados de fluorescentes. Os processos denominados fosforescentes requerem um estado intermediário tripleto, devido a reversão do spin entre o estado fundamental e o excitado, o qual retarda a emissão levando a estados excitados com tempo de vida longo $\left(>10^{-6} \mathrm{~s}\right)$.

No estado excitado singleto, o elétron excitado está emparelhado ao elétron que permaneceu no estado fundamental. Dessa forma, o spin retorna ao estado fundamental com a emissão de um fóton. Esse processo de transição eletrônica possui um tempo característico próximo a $10 \times 10^{-9} \mathrm{~s}$ sendo denominado fluorescência. Para que ocorra determinada transição, a energia absorvida deve ser equivalente à diferença entre o estado eletrônico inicial e o excitado. Este valor representa o $\lambda$ de excitação e é característico de uma estrutura molecular em particular. No retorno ao estado fundamental, o elétron emite energia que pode manifestar-se em forma de calor ou emissão de fótons com um $\lambda$ específico, chamado $\lambda$ de emissão, logo a energia emitida é menor que a absorvida por causa das perdas na forma de calor ou vibrações moleculares.

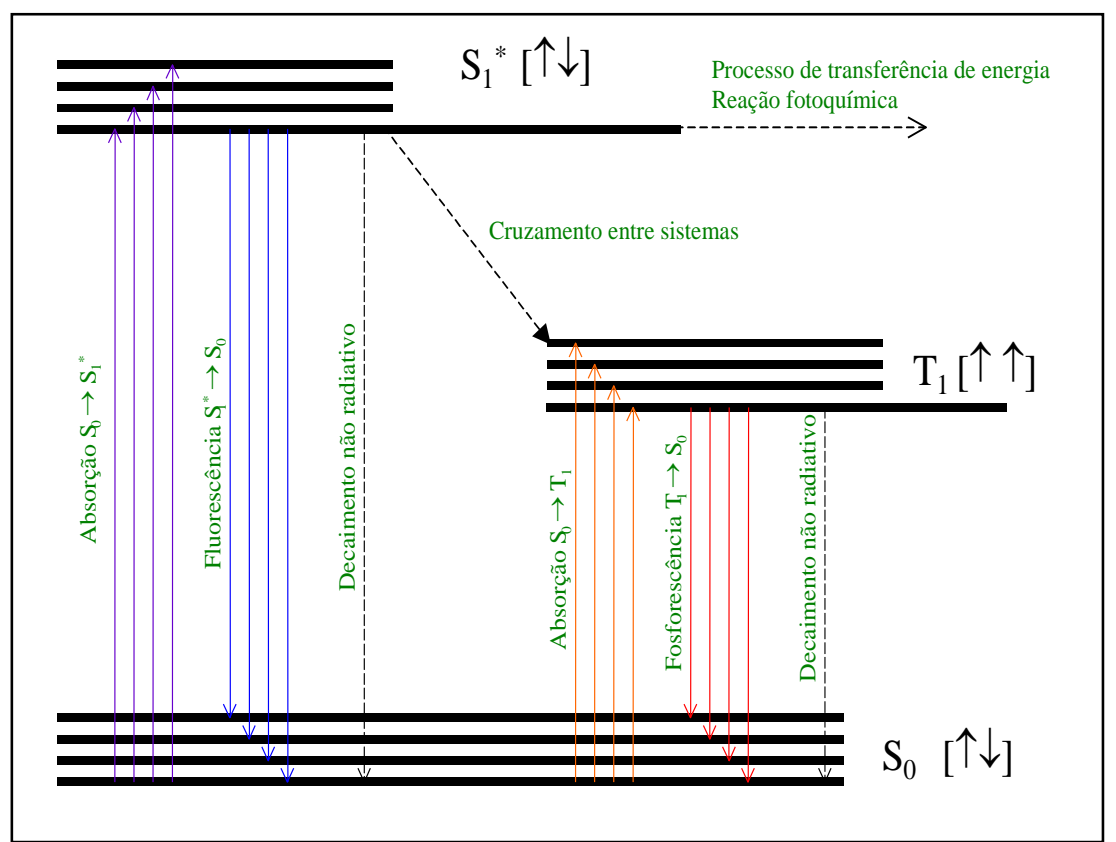

Figura 14: Níveis vibracionais e eletrônicos de uma molécula orgânica, e caminhos de decaimento radiativos e não radiativos 
$\mathrm{Na}$ fluorescência, transições típicas envolvem a promoção de elétrons não ligantes (n) ou ligantes $(\pi)$ para orbitais antiligantes $\pi^{*}$. Esses são altamente prováveis em compostos denominados fluoróforos, os quais são sistemas moleculares contendo átomos com pares de elétrons não compartilhados, tais como, oxigênio e nitrogênio e em estruturas aromáticas e/ ou alifáticas conjugadas de insaturações com alto grau de ressonância, isto é, deslocalização eletrônica, como é observado para as SH do solo (SENESI et al., 1991).

Não existe uma definição clara com respeito à composição química e estrutural da MO presente no solo. Sabe se, por exemplo, que os principais constituintes desse material são as SH. Porém, a estrutura química dessas substâncias ainda é indefinida, pois existem grandes variações com relação a sua composição elementar, massa molecular, e concentração e tipos de grupos funcionais.

O uso da fluorescência nos estudos das SH apóia-se na presença de várias estruturas fluorescentes intrínsecas à molécula húmica e seus precursores, particularmente aromáticos, fenóis e grupos quinona (SENESI et al., 1991). Estruturas fluorescentes nativas ou incorporadas às SH constituem apenas uma pequena porção da macromolécula húmica, entretanto, sua variedade e a dependência de suas propriedades do meio de origem, permitem a obtenção de informações sobre seu comportamento fluorescente e sobre a natureza química da SH (SENESI e LOFFREDO, 1999). O comportamento fluorescente médio da molécula é o resultado da soma de todos os espectros individuais dos diferentes fluoróforos da molécula.

A espectroscopia de fluorescência tem sido usada para avaliar o índice de humificação da matéria orgânica do solo (KALBITZ et al., 2000; OHNO, 2002; MILORI et al., 2002; CARVALHO et al., 2004). Para tal, têm sido propostas metodologias utilizando modalidades de emissão e de varredura sincronizada.

Ademais, ampla também tem sido a aplicação desta técnica na diferenciação estrutural de SH extraídas de solos, com e sem adubação realizada com rejeitos orgânicos (lodos) (BERTONCINI et al., 2005; PLAZA et al., 2006; SANTOS et al., 2010), no estudo das reações de metais, como o $\mathrm{Cu}^{2+}, \mathrm{Zn}^{2+}$ e $\mathrm{Ni}^{2+}$ por $\mathrm{SH}$ extraídas de turfas, compostos e solos (PLAZA et al., 2005; PROVENZANO et al., 2004).

\subsubsection{1 - MODALIDADE DE EMISSÃO}

Em um espectro de emissão costuma-se definir um comprimento de onda específico para excitação das moléculas da amostra. O comprimento de onda da radiação incidente é definido a partir do espectro de absorção da amostra, sendo aquele no qual houve maior 
intensidade de radiação absorvida. Mantendo-se fixo o comprimento de onda de excitação é possível obter os comprimentos de onda e as intensidades das emissões provenientes da relaxação dos componentes da amostra.

MILORI et al., (2002) propuseram utilizar como índice de humificação a área do espectro de emissão medido com o maior comprimento de onda correspondente ao máximo de intensidade de fluorescência obtido no espectro de excitação. Esta seria uma medida relativa à quantidade de compostos mais condensados e mais aromáticos. Denominou-se $\mathrm{A}_{465} \mathrm{o}$ índice de humificação determinado segundo MILORI et al., (2002), que neste caso é igual a integral da região total do espectro de emissão (Figura 15) da amostra com comprimento de onda de excitação $\lambda_{\text {exc }}=465 \mathrm{~nm}$.

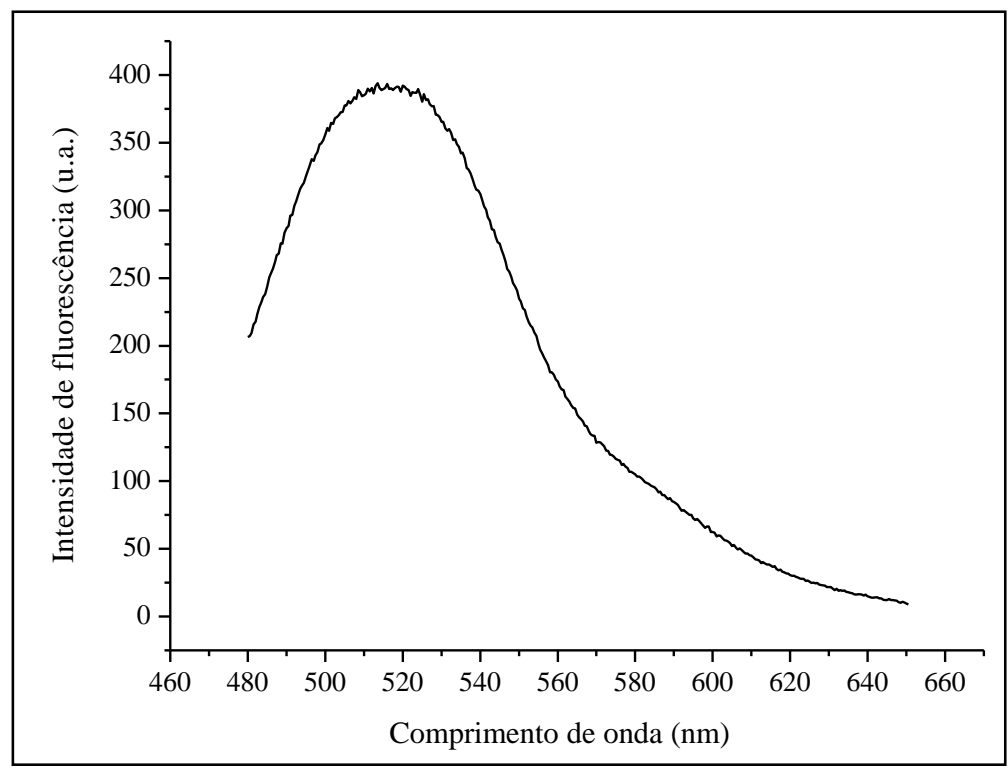

Figura 15: Espectro de emissão de fluorescência de AH extraídos de solo tratado com lodo de esgoto, obtido segundo metodologia de MILORI et al., (2002). Comprimento de onda de excitação $\lambda_{\text {exc }}=465 \mathrm{~nm}$ (NARIMOTO, 2006)

\subsubsection{2 - MODALIDADE SINCRONIZADA}

O espectro de varredura sincronizada é obtido monitorando-se os comprimentos de onda de excitação e emissão de forma sincronizada com um intervalo constante entre ambos, onde $\Delta \lambda=\lambda_{\text {em }}-\lambda_{\text {exc }}$. Ao utilizar a modalidade de emissão síncrona para estudar amostras contendo uma grande variedade de compostos orgânicos, tais como as SH, aumentam-se as chances de ocorrência de sobreposição de picos, podendo gerar distorções no sinal de fluorescência. No entanto, a resolução de um espectro de fluorescência pode ser comprimida ou expandida conforme diminui-se ou aumenta-se o valor de $\Delta \lambda$ (VO-DINH, 1978). KALBITZ et al., (2000) sugeriram um valor de $\Delta \lambda=55 \mathrm{~nm}$ para avaliar o índice de 
humificação da matéria orgânica do solo. Nesta metodologia, os espectros de fluorescência sincronizados das SH apresentam dois picos em torno de 360 e $400 \mathrm{~nm}$ e um ombro próximo a $470 \mathrm{~nm}$. Esse perfil muda dependendo do índice de humificação da matéria orgânica, podendo ser avaliado medindo-se a razão entre a intensidade de fluorescência em 400 e 360 $\mathrm{nm}$ ou em 470 e $360 \mathrm{~nm}$. A Figura 16 mostra um espectro de fluorescência sincronizada obtido para uma solução de ácido húmico extraído de solo tratado com lodo de esgoto.

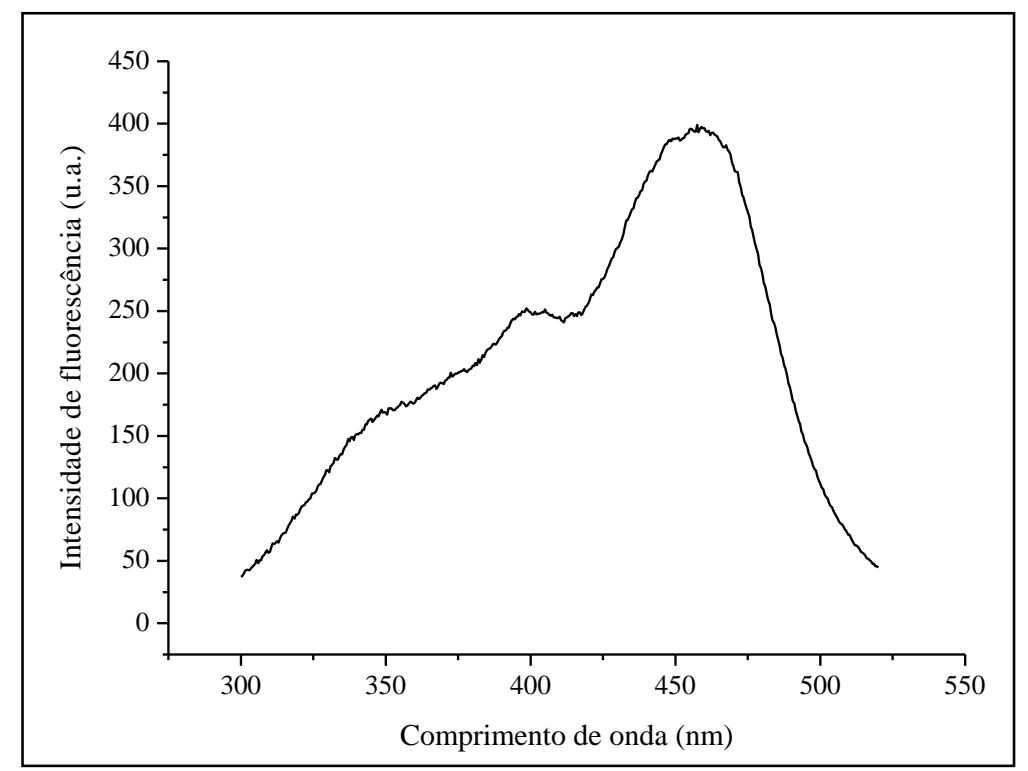

Figura 16: Espectro de varredura sincronizada de AH extraídos de solo tratado com lodo de esgoto, obtido segundo metodologia de KALBITZ et al., (2000). $\Delta \lambda=55 \mathrm{~nm}$ (NARIMOTO, 2006)

\subsection{4 - ESPECTROSCOPIA DE FLUORESCÊNCIA INDUZIDA POR LASER (FIL)}

A técnica de Fluorescência Induzida por Laser (FIL) se baseia no mesmo princípio descrito para fluorescência na sessão anterior. A diferença consiste apenas no fato da excitação do material fluorescente ser feita através de um laser. O uso do laser apresenta vantagens como intensidade de luz mais alta num comprimento de onda de excitação específico produzindo assim boa relação sinal-ruído quando comparada à fluorescência induzida por lâmpada, e maior seletividade na excitação tendo, portanto, menos fatores de interferência no sinal da fluorescência.

A espectroscopia de fluorescência induzida por laser tem se mostrado eficiente na análise da matéria orgânica de solos, fornecendo resultados satisfatórios de forma ágil, limpa e em condições próximas das naturais, visto que as amostras de solo não precisam ser submetidas a um tratamento prévio, como necessário em outras técnicas tais como 
Ressonância Magnética Nuclear e Ressonância Paramagnética Eletrônica, entre outras (MILORI et al., 2003; MILORI et al., 2004; MILORI et al., 2006).

A fluorescência do solo tem origem na MOS, pois essa possui grupos funcionais ricos em ligações insaturadas contidas em sistemas rígidos. Esses grupos, denominados fluoróforos, estão presentes principalmente na MOS mais humificada, tais como $\mathrm{OH}$ fenólicos livres e ligados, estruturas de quinona, grupos carboxílicos ligados e anéis aromáticos.

Utilizando a FIL, MILORI et al., (2004) propuseram para obtenção do índice de humificação $\left(\mathrm{H}_{\mathrm{FIL}}\right)$, a razão entre o valor da área sob a curva de fluorescência (ACF) com excitação em $458 \mathrm{~nm}$ e a porcentagem de carbono orgânico total (COT) presente na amostra de solo,

$$
\mathrm{H}_{\mathrm{FIL}}=\mathrm{ACF} / \mathrm{COT}
$$

a qual visa normalizar a relação entre intensidade de emissão e a concentração de grupamentos fluoróforos presentes na matéria orgânica da amostra.

MILORI et al. (2006) descrevem o sensor de Matéria Orgânica de solos portátil, desenvolvido pela Embrapa Instrumentação Agropecuária, utiliza a técnica de fluorescência induzida por laser (FIL) para observar a fluorescência da porção humificada da matéria orgânica do solo intacto, sem a necessidade de processos de fracionamento. O protótipo compacta em um só sistema todo o aparato de detecção e análise de matéria orgânica e permite a utilização do equipamento fora das condições do laboratório (Figura 17).
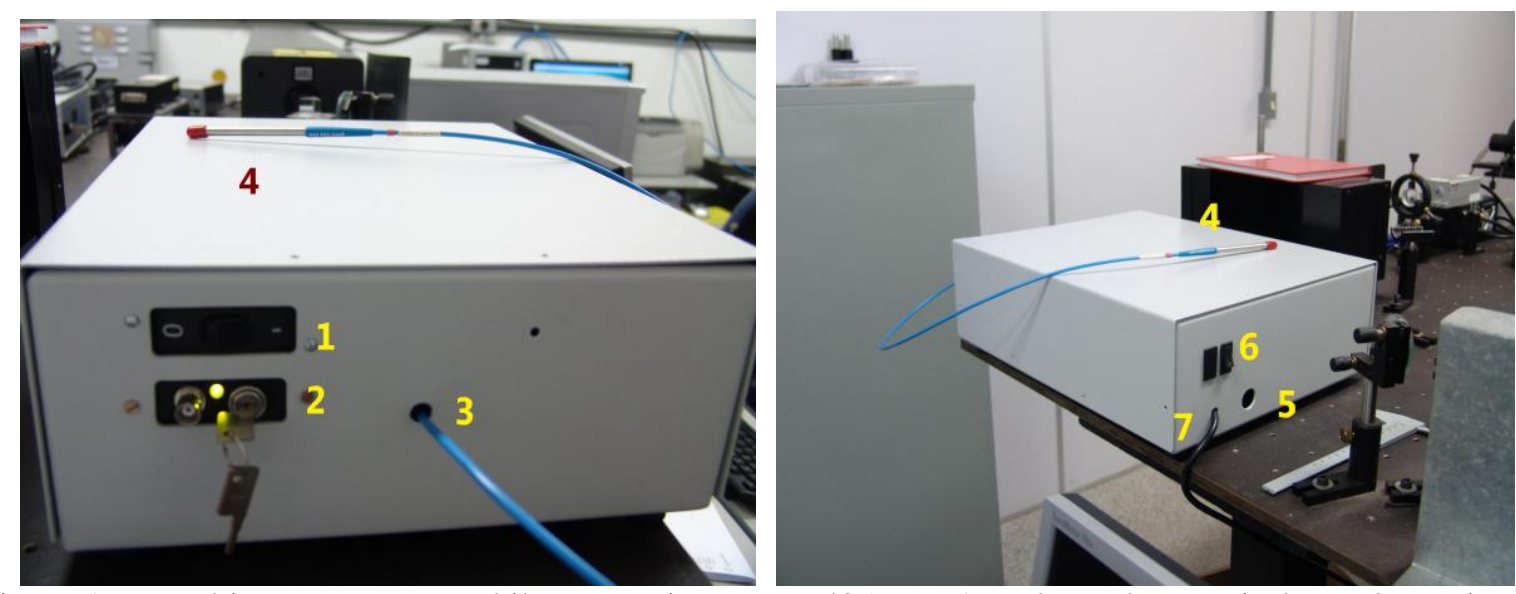

Figura 17: Protótipo para FIL portátil com excitação em 405 nm: 1 - chave de energia laser; 2 - caixa de controle laser; 3 - saída para o cabo óptico; 4 - ponta emissora/coletora do cabo óptico; 5 - saída para USB e porta paralela; 6 - chave geral da caixa e fusível de protecão; 7 - cabo de força geral (MILORI et al., 2006).

O sistema (Figura 18) possui um laser de diodo (Coherent CUBE) que emite luz laser em 405nm, com potencia máxima de 50mW (1). Essa radiação é conduzida até a amostra (7) 
através de um cabo óptico acoplado ao laser (2), e um cabo ótico de excitação (5) acoplado ao filtro atenuador ( 3 e 4). O filtro atenua o efeito da reflectância da luz laser na amostra. O cabo óptico de excitação (corte transversal em 11) é composto por seis fibras ópticas de excitação (12) (diâmetro de $400 \mu \mathrm{m}$, comprimento de $2 \mathrm{~m}$ abertura numérica de 0,22 - Ocean Optics) que excitam a amostra. A fluorescência e a refletância da amostra são coletadas por uma fibra óptica central deste mesmo cabo óptico que conduziu a excitação (13). Após ser filtrado para atenuar o efeito da refletância, o sinal é conduzido até um miniespectrômetro de alta sensibilidade (9) (abertura de entrada de $200 \mu \mathrm{m}$, grade de 600 linhas por milímetro e janela de sensibilidade de 380nm a 1058nm - Ocean Optics) através de um cabo óptico de emissão (8) (diâmetro $1000 \mu \mathrm{m}$, comprimento de $2 \mathrm{~m}$ e abertura numérica de 0,22 - Ocean Optics). A emissão da amostra é então decomposta através de uma grade de difração fixa e detectada por um array de fotodiodos previamente calibrados. Desta forma, obtêm-se o espectro de emissão que será enviado para um computador (10). Este fará o controle, a aquisição e o tratamento dos dados por meio de um software de aquisição de dados. A montagem e os componentes do sistema podem ser vistos na Figura 18.
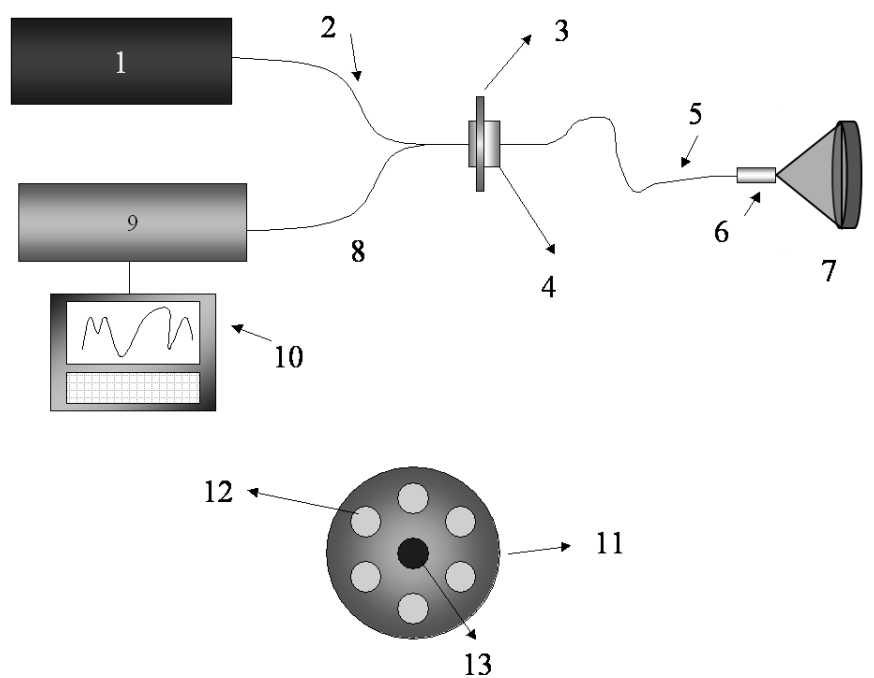

Figura 18: Esquema da montagem do sistema FIL portátil. 1 - laser; 2- cabo óptico de excitação; 3 - filtro óptico ajustável; 4 - acoplador de fibra óptica; 5 - cabo óptico misto; 6 - sonda; 7 - amostra de solo; 8 - cabo óptico de emissão; 9 - miniespectrômetro; 10 - computador portátil para aquisição de dados; 11 - corte transversal do cabo óptico misto; 12 - fibras óptica de excitação; 13 - fibra óptica para coletar emissão (MILORI et al., 2006). 


\section{8 - POTENCIAL ZETA E MEDIDA DE TAMANHO DE PARTÍCULAS}

Em uma dispersão coloidal aquosa, a maioria das partículas carrega uma carga elétrica. Esta carga de superfície pode ter muitas origens, dependendo da natureza da partícula e do meio ao redor (GUINGAB et al., 2007). Uma das origens é devido à dissociação de alguns grupos ácidos $(\mathrm{H}+)$ ou alcalinos $(\mathrm{OH}-)$, o que torna a superfície da partícula carregada negativamente ou positivamente, respectivamente. Além disso, a magnitude da carga na superfície dependerá da força que ácidos e bases exercem na superfície, e do pH da solução (ALVAREZ-PUEBLA et al., 2005; GUINGAB et al., 2007). Desta forma, uma distribuição de cargas na superfície da partícula afeta a distribuição de íons em volta da região de interface, resultando num aumento na quantidade de íons (íons de carga oposta àquela da partícula) perto da superfície. Assim sendo, há a formação de uma dupla camada elétrica em torno de cada partícula (Figura 19).

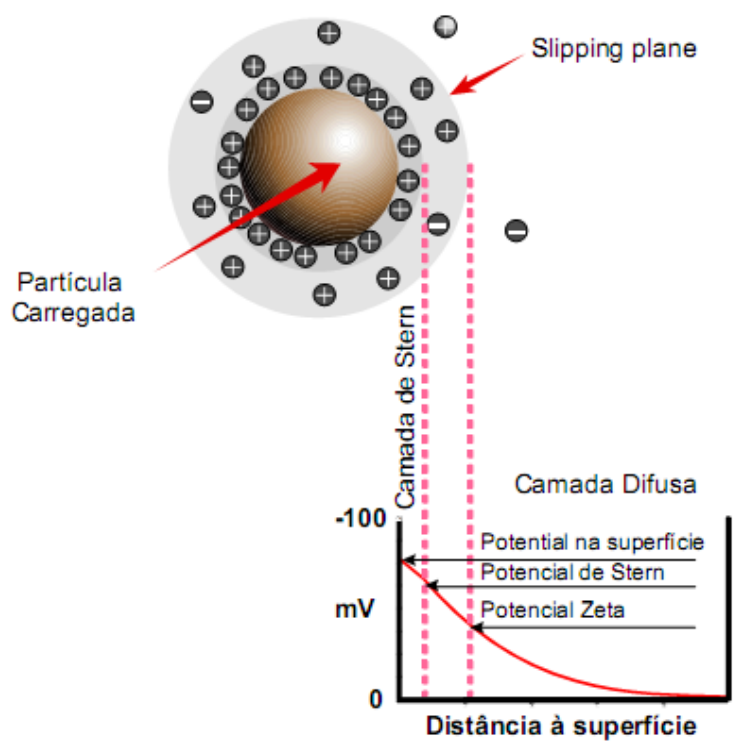

Figura 19: Representação da dupla camada elétrica e da variação do potencial Zeta com a distância de uma partícula carregada negativamente.

As Medidas de potencial Zeta são usadas para avaliar a estabilidade de sistemas coloidais. Segundo (GUINGAB et al., 2007), o fator mais importante que afeta o potencial Zeta é o pH. Um valor de potencial Zeta sozinho, sem a associação de um valor de $\mathrm{pH}$ e sem a descrição do ambiente é um número virtualmente sem sentido. Por exemplo, se há uma partícula com potencial Zeta negativo em solução, e se for adicionada a essa suspensão uma solução alcalina, $(\mathrm{OH}-)$ então a partícula tenderá a adquirir mais cargas negativas. Se uma 
solução ácida for adicionado $(\mathrm{H}+)$ chegará um ponto em que a carga negativa será neutralizada. Com o aumento da concentração de ácido, a partícula terá carga positiva. Desta forma uma curva de potencial Zeta versus $\mathrm{pH}$ será positiva nos valores inferiores de $\mathrm{pH}$ e negativa nos valores superiores de $\mathrm{pH}$, como mostra a Figura 20.

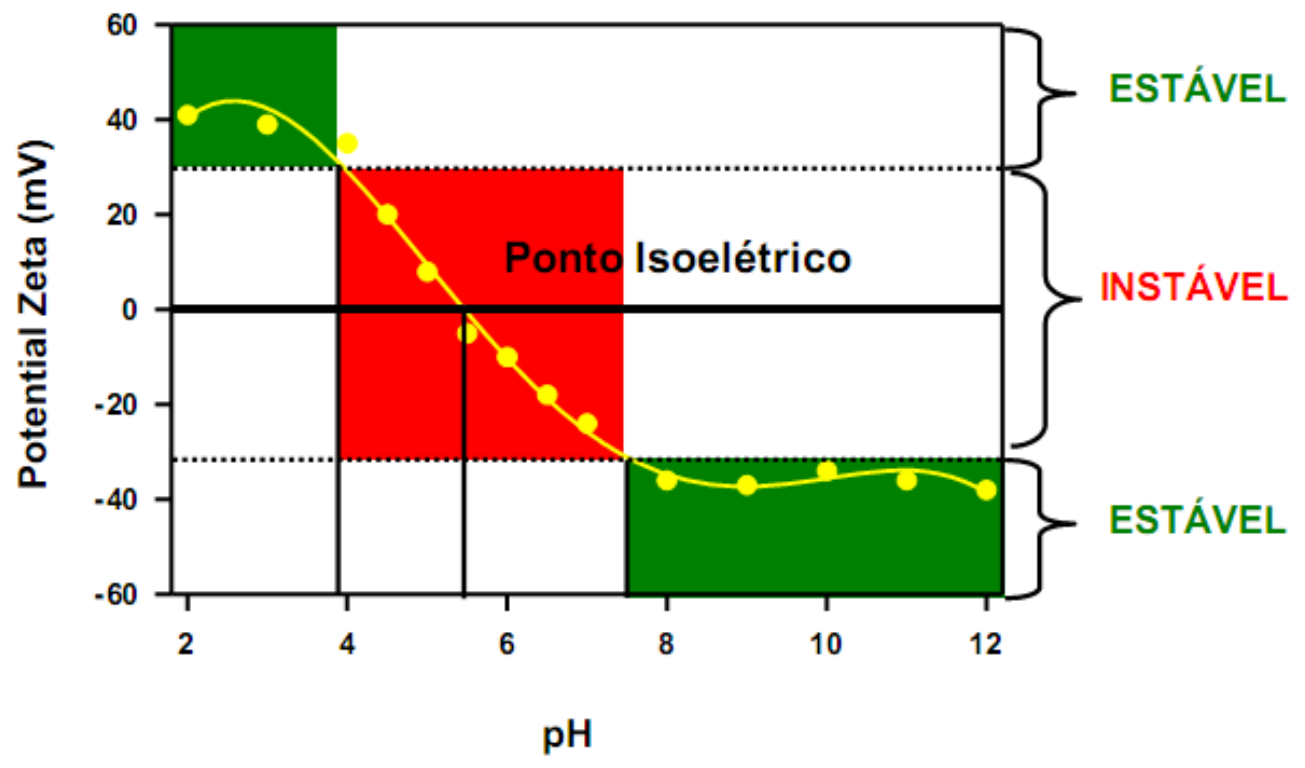

Figura 20: Curva de potencial Zeta em função de $\mathrm{pH}$

O ponto de intersecção do $\mathrm{pH}$, onde o potencial Zeta é zero, é chamado de ponto isoelétrico, e é muito importante, pois é neste ponto que o sistema coloidal apresenta menor estabilidade (Figura 20). Nesta região, a agregação das partículas é favorecida. No caso apresentado na Figura 20, observa-se que entre o pH 4 e 8 as partículas estão instáveis. Fora deste intervalo as cargas são suficientes para conferir estabilidade às partículas. O ponto isoelétrico está em torno do $\mathrm{pH} 6$.

Como conseqüência da existência de cargas elétricas na superfície é que as partículas serão afetadas quando ocorrer aplicação de um campo elétrico.

Quando um campo elétrico é aplicado através de eletrodos, as partículas carregadas suspensas no eletrólito são atraídas para o eletrodo de carga oposta (JACKSON, 1998). As partículas movem-se com uma velocidade característica que é dependente da força do campo elétrico aplicado (medido pelo equipamento), da viscosidade e da constante dielétrica do meio e do potencial Zeta. A velocidade da partícula em unidade de campo elétrico é conhecida como sendo mobilidade eletroforética. O potencial Zeta relaciona-se com a mobilidade eletroforética pela Equação de Henry - Equação 4 - (PAL et al. 2007): 
Eq. 4 :

$$
U_{E}=\frac{2 \varepsilon \zeta f(K a)}{3 \eta}
$$

$U_{E}$ : mobilidade eletroforética;

$\zeta$ : potencial Zeta;

$\varepsilon$ : constante dielétrica;

$\eta$ : viscosidade;

Onde:

As unidades de $K$ são comprimento recíproco e $1 / K$ a "espessura" da dupla camada elétrica (o comprimento de Debye); $a$ é o raio da partícula; Ka é a relação do raio da partícula com a espessura da dupla camada (ZETA SIZER NANO USER MANUAL, 2007) .

Em meios polares, o valor máximo de $f(K a)$ para partículas é 1,5 , de acordo com a aproximação de Smoluchowski; e para em meios apolares o valor máximo de $f(K a)$ é 1, segundo aproximação de Hückel.

A aplicação de um campo elétrico no capilar da cela onde a amostra é colocada, e cuja superfície é carregada, faz o líquido (amostra) fluir pelas paredes da cela, através de eletrosmose (Figura 21).

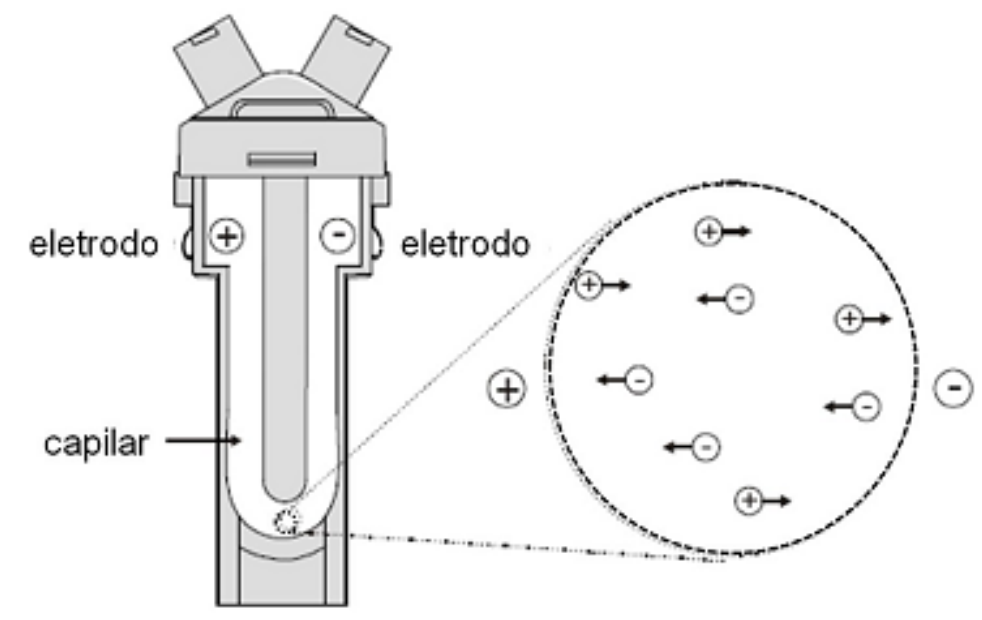

Figura 21: Cela capilar com eletrodo. Em destaque o movimento de cargas na camada Estacionária

As partículas coloidais serão sujeitas a este fluxo sobreposto à sua mobilidade eletroforética, e este precisa ser levado em consideração. Entretanto, em um sistema fechado o fluxo ao longo das paredes pode ser compensado por um fluxo reverso na parte central de baixo do capilar em um perfil parabólico. Neste ponto da cela no qual o fluxo eletrosmótico é 
zero, é medida a velocidade da partícula devido à sua verdadeira mobilidade eletroforética. Este ponto é chamado de camada estacionária (Figura 21).

Um sistema de eletroforese consiste de uma cela capilar com eletrodos em sua parte final, onde o potencial é aplicado. Os métodos mais antigos para medir a mobilidade eletroforética envolvem a observação individual de partículas usando um microscópio e cronometrando o seu trânsito através de uma grade. Já as tecnologias atuais, utilizam a medida da velocidade de laser Doppler (LDV, do inglês, laser Doppler velocimetry).

Neste caso, conforme mostra a Figura 22, feixes de laser são alinhados na camada estacionária na cela. No ponto de cruzamento dos campos, franjas devido à interferência de Young com espaçamentos conhecidos são formados. Partículas se movendo através das franjas sofrem a influência do campo elétrico aplicado espalham a luz na qual a intensidade flutua com uma freqüência que é relacionada com a velocidade da partícula (ZETA SIZER NANO USER MANUAL, 2007).

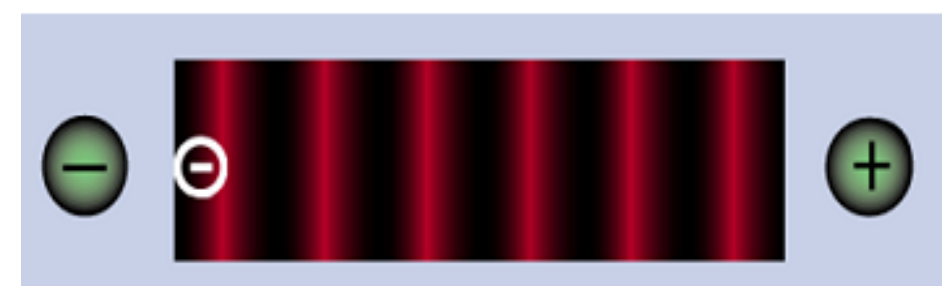

Figura 22: Figura de interferência formada, utilizada para medida de mobilidade eletroforética em sistemas mais modernos.

Os fótons detectados são enviados para um equipamento digital que estabelece a correlação. Um espectro de freqüência é produzido e conseqüentemente, a mobilidade e o potencial Zeta são calculados (Figura 23). 


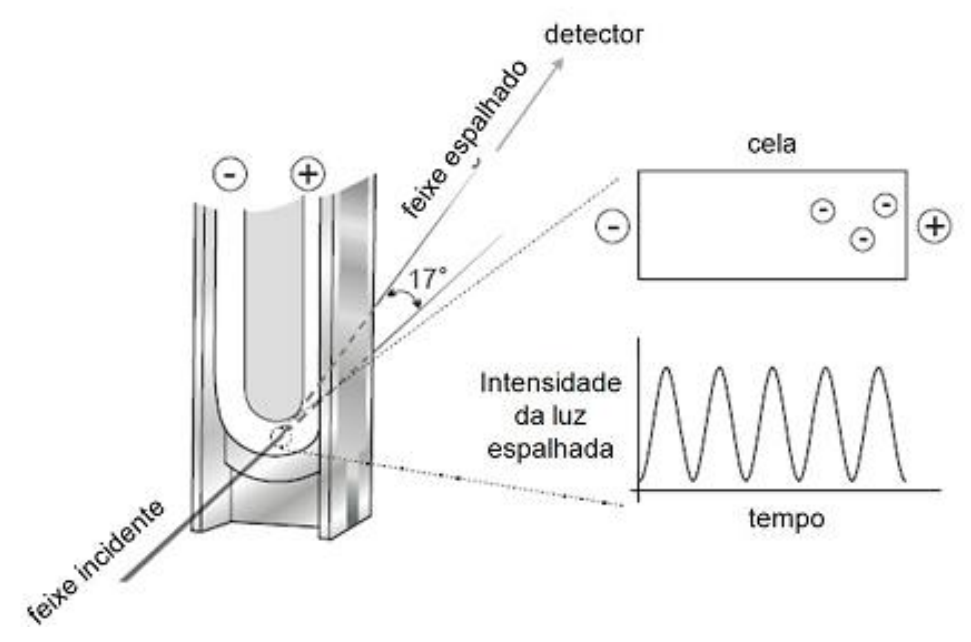

Figura 23: Medida de mobilidade eletroforética em sistemas mais modernos.

Em relação à medida do tamanho de partículas, o medidor utiliza o Espalhamento dinâmico de luz (DLS, do inglês, dynamic light scattering). Trata-se de uma técnica utilizada para a determinação do tamanho de partículas em soluções coloidais, onde a amostra é iluminada por um laser e a intensidade da luz espalhada resultante é dependente do tamanho da partícula. Análises dessas flutuações de intensidade fornecem o coeficiente de difusão e através deste pode-se calcular o tamanho das partículas.

Sabe-se que partículas suspensas em líquido nunca estão paradas, mas sempre se movendo constantemente devido ao movimento Browniano e devido às colisões aleatórias com as moléculas do solvente que envolve a partícula. A característica importante do movimento Browniano para o DLS é que partículas pequenas movem-se mais rapidamente que as partículas maiores: partículas maiores se movem mais lentamente e espalham mais o laser; partículas menores se movem mais rapidamente e espalham menos o laser. A relação entre o tamanho da partícula e sua velocidade devido ao movimento Browniano é definida pela equação de Stokes-Einstein (Equação 5):

Eq. 5:

$$
\begin{aligned}
& \mathrm{R}_{\mathrm{H}} \text { : raio hidrodinâmico; }
\end{aligned}
$$

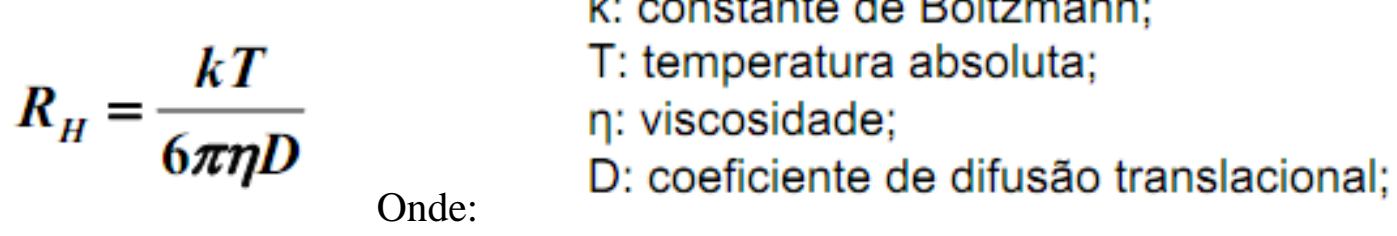


A técnica consiste na medida das flutuações dependentes do tempo da intensidade da luz espalhada pelas partículas que estão em constante movimento Browniano, e relaciona este com o tamanho da partícula. Isto decorre do fato que uma partícula pequena, iluminada por uma fonte de luz espalhará luz em todas as direções. A velocidade do movimento Browniano é medida e é chamada de coeficiente de difusão translacional D (do inglês, translational diffusion coefficient). Este coeficiente de difusão pode ser convertido para diâmetro hidrodinâmico (DH) usando a equação de Stokes-Einstein (ZETA SIZER NANO USER MANUAL, 2007).

Os resultados de um experimento de DLS podem ser apresentados como uma distribuição da intensidade de espalhamento, do número de partículas e do volume das partículas em função do diâmetro (ou raio) das partículas.

Diversos estudos apontam tendências do ponto de vista do comportamento deste material quando em solução, resultando em divergências e sugerindo predominância do modelo macromolecular (SENESI et al, 1993) ou supramolecular (PICCOLO et al , 2001) para a estrutura das substâncias húmicas.

Como descrito na literatura, as substâncias húmicas apresentam características de colóide, e o emprego das medidas de potencial zeta e tamanho de partículas mostrou-se como uma alternativa investigativa para abordar algumas características inerentes às substâncias húmicas, quando em solução variando-se a concentração iônica e o valor de $\mathrm{pH}$ do meio (SIMÕES, 2005).

Medidas de potencial zeta e tamanho de partículas articularam-se como uma nova ferramenta no estudo das substâncias húmicas. PEDRÓT et al. (2010), por exemplo, destaca estas técnicas nos estudos envolvendo a interação de substâncias húmicas e alguns íons metálicos. Ressalta-se, entretanto, que sua utilização para tal finalidade ainda apresenta carência, especialmente no que diz respeito ao estudo de solos de clima tropical, como as amostras estudadas neste trabalho. 


\section{CAPÍTULO 3 - OBJETIVOS}

Este trabalho objetivou a realização de um estudo detalhado acerca do impacto na matéria orgânica do solo submetido à fertirrigação controlada de efluente tratado por uma unidade modelo de biodigestor anaeróbio, instalado em uma Escola Técnica do Centro Paula Souza.

De modo específico, pretendeu-se:

- Caracterizar a qualidade do efluente produzido pelo biodigestor

- Extrair e fracionar as substâncias húmicas, estabelecendo uma comparação entre amostras de solos adubados convencionalmente, amostras irrigadas com diferentes concentrações do efluente e amostras de solo testemunha (branco), o qual nunca recebeu nenhum dos tratamentos anteriores; além de caracterizar a matéria orgânica do solo e as substâncias húmicas extraídas por meio de diversas técnicas físico-químicas.

- Observar possíveis modificações ocorridas na matéria orgânica do solo após aplicação controlada do efluente, tanto do ponto de vista quantitativo quanto qualitativo, visando manejo adequado desse recurso hídrico como fertilizante. 


\section{CAPÍTULO 4 - MATERIAIS E MÉTODOS}

\section{1 - DESCRIÇÃO DO CAMPO EXPERIMENTAL}

O experimento foi instalado em uma área experimental da Escola Técnica Estadual Astor de Mattos Carvalho, em Cabrália Paulista/SP. O solo da área experimental é classificado como Argissolo Vermelho Amarelo, apresentando uma topografia relativamente plana e bem drenado.

Neste local também encontra-se instalada a unidade modelo do biodigestor anaeróbio, inaugurada no ano de 2008, fruto de uma parceria entre a Embrapa, o Centro Paula Souza, com apoio da Firestone Building Products, Ecosys e Prefeitura Municipal de Cabrália Paulista.

\subsection{1 - UNIDADE BIODIGESTOR}

A unidade modelo de biodigestor anaeróbio utilizada (Figura 24) representa um sistema de médio porte do tipo tubular (também conhecido como Biodigestor Canadense), com capacidade para armazenar aproximadamente $250 \mathrm{~m}^{3}$ de líquidos em seu interior, o suficiente para produzir, pelo menos, 13 metros cúbicos de biogás e 6 metros cúbicos de fertilizante orgânico diariamente. As dimensões do biodigestor são de 50,5 m de comprimento, 1,8 $\mathrm{m}$ de profundidade, 4,5 $\mathrm{m}$ de largura (superior) e 1,0 $\mathrm{m}$ (inferior) com um corte transversal em formato de trapézio regular. Foi utilizada geomembrana de EPDM (borracha de etilenopropileno-dieno) fornecida pela Firestone Building Products. Na saída do biodigestor existe uma caixa de coleta do efluente tratado com capacidade para receber $25 \mathrm{~m}^{3}$ de líquido (DA SILVA, et al., 2010).

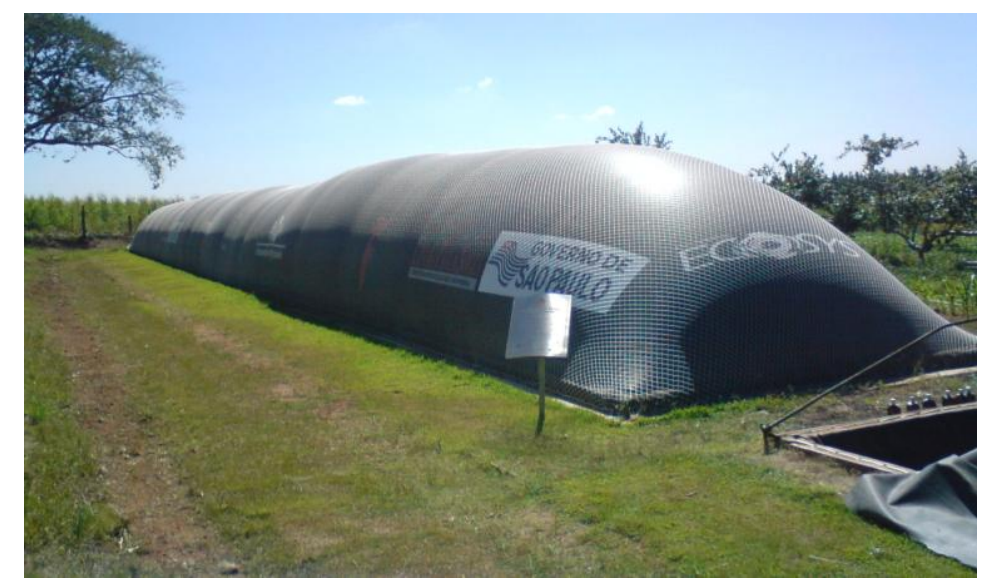

Figura 24: Unidade modelo de biodigestor anaeróbio instalado na ETEC Astor de Mattos Carvalho 
Durante o experimento, o biodigestor recebia um volume diário que variava de 8 a $10 \mathrm{~m}^{3}$, indicando um tempo mínimo de retenção hídrica de 25 dias. $\mathrm{O}$ afluente era composto pelo esgoto gerado por 100 alunos (somente vaso sanitário), morando em semi-internato, e 50 suínos em fase de crescimento e terminação, cujas baias eram lavadas duas vezes ao dia. A composição volumétrica do afluente era em média 50\% de dejetos humanos e 50\% de dejetos suínos. O biodigestor não recebia água de chuva.

\subsection{2 - O EXPERIMENTO DE CAMPO}

O campo experimental foi delineado, conforme ilustra a Figura 25.

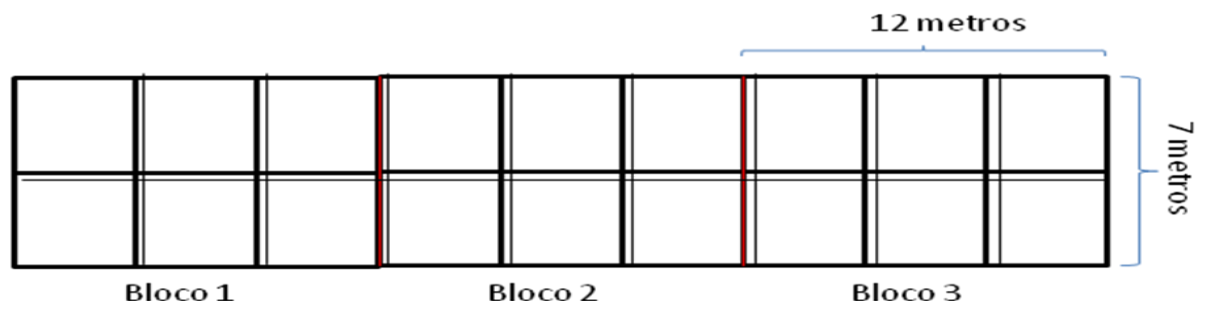

Figura 25: Delineamento do campo experimental

A área experimental teve a dimensão de $252 \mathrm{~m}^{2}$ e foi composta por 3 blocos de 6 parcelas cada, propiciando que cada amostra seja feita em 3 repetições. Entre cada parcela e cada bloco, um espaço de 1 metro foi deixado para facilitar a entrada e passagem durante a irrigação. As parcelas foram definidas ao acaso, e cada um dos blocos teve uma parcela excluída, adquirindo a constituição representada na Figura 26.

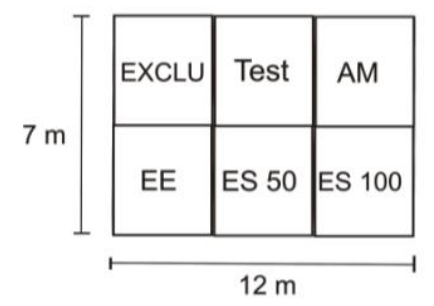

Figura 26: Representação das parcelas em um dos blocos.

A cultura conduzida no campo experimental foi uma cultura anual (sorgo) cujo início do plantio se deu no mês de outubro de 2009.

Visando observar comparativamente as modificações na estabilidade da matéria orgânica no solo fertirrigado ao longo do cultivo de sorgo, as doses aplicadas do efluente tratado corresponderam a concentrações equivalentes em fósforo total, maiores ou menores 
que a dose de adubação mineral recomendada pelo Boletim Técnico 100, do IAC -Instituto Agronômico de Campinas (VAN RAIJ et.al., 1997). São elas, respectivamente: a dose equivalente à adubação mineral recomendada; 50\% e 100\% acima da dosagem recomendada, além do solo testemunha (branco - sem aplicação de efluente ou adubação mineral) e a própria adubação mineral convencional a base de nitrogênio fósforo e potássio (NPK), as quais receberam apenas a irrigação feita com água (Tabela 3).

Tabela 3: Descrição das amostras e tratamentos aplicados nas parcelas

\begin{tabular}{c|c}
\hline Identificação & Amostra \\
\hline Test & $\begin{array}{c}\text { Solo testemunha (branco - sem aplicação de efluente ou } \\
\text { adubação mineral) }\end{array}$ \\
\hline AM & $\begin{array}{c}\text { Solo submetido à adubação mineral } \\
\text { EE }\end{array}$ \\
\hline E 50 & $\begin{array}{c}\text { Irrigação feita com efluente do biodigestor em dosagem } \\
\text { de nutrientes equivalente à recomendada pelo IAC }\end{array}$ \\
\hline E 100 & $\begin{array}{c}\text { Irrigação feita com efluente em dosagem 50\% superior à } \\
\text { recomendada }\end{array}$ \\
\hline
\end{tabular}

A Figura 27 ilustra o campo experimental antes do plantio e após a aplicação do efluente nas parcelas:

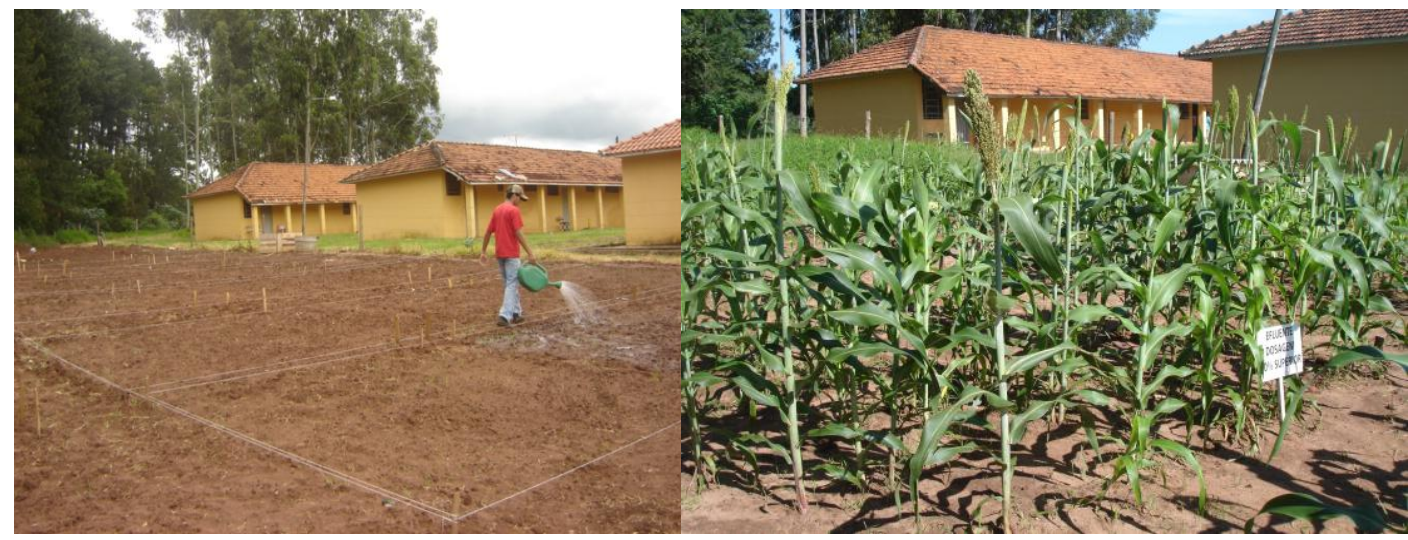

(a)

(b)

Figura 27: (a) Após preparo do solo, início do plantio e primeira irrigação e (b) Cultivo de sorgo em uma das parcelas- dosagem de efluente 50\% acima da recomendada, ilustrando como as parcelas estavam identificadas para auxílio na irrigação.

Baseando-se na concentração média de macro e micronutrientes presentes no efluente, foi calculado com base na concentração de fósforo o volume de efluente necessário para aplicação em cada tratamento. Para tal, também foram levadas em consideração as 
necessidades de macro e micronutrientes requeridas pela cultura de sorgo. A Tabela 4 descreve os volumes de efluente aplicados, bem como a dosagem utilizada de adubação mineral convencional. Apresenta-se também o volume de água utilizado em cada caso, de modo que cada tratamento recebesse irrigação com mesmo volume final. Deste modo, as parcelas que necessitaram de um volume menor de efluente tiveram o volume final ajustado com água, previamente misturado ao efluente. As parcelas TEST e AM receberam apenas água.

Tabela 4: Volume de efluente e água e concentração de adubação mineral aplicados a cada um dos tratamentos:

\begin{tabular}{|c|c|c|c|}
\hline Identificação & $\begin{array}{c}\text { Adubação Mineral } \\
\left(\text { Kg há }^{-1}\right)\end{array}$ & $\begin{array}{l}\text { Volume total de } \\
\text { efluente aplicado } \\
\left(\mathrm{L} \mathrm{m}^{-2}\right)\end{array}$ & $\begin{array}{l}\text { Volume total de } \\
\text { água aplicado } \\
\left(\mathrm{L} \mathrm{m} \mathbf{~ m}^{-2}\right)\end{array}$ \\
\hline TEST & -- & - & 344 \\
\hline $\mathbf{A M}$ & $\begin{array}{l}\text { Nitrogênio: } 20 \\
\text { Fósforo: } 80 \\
\text { Potássio: } 50\end{array}$ & -- & 344 \\
\hline EE & - & 172 & 172 \\
\hline E50 & -- & 258 & 86 \\
\hline E100 & -- & 344 & -- \\
\hline
\end{tabular}

Observou-se que ao calcular-se o volume de efluente a ser aplicado pela concentração de nitrogênio, o teor de fósforo não atendia às necessidades requeridas pelo sorgo. Por essa razão, o cálculo baseado no teor desse nutriente.

No momento do plantio, foi realizada irrigação com $50 \%$ do volume estipulado para cada tratamento, e ao longo das semanas, o restante do volume foi aplicado. As aplicações encerraram-se em fevereiro de 2010 para as parcelas que necessitavam de maior volume de efluente, em decorrência das constantes chuvas ocorridas na região durante os meses nos quais o experimento acontecia.

Em março de 2010, coletaram-se as amostras compostas das parcelas em cada um dos blocos, em seis profundidades diferentes $(0-10 \mathrm{~cm} 10-20 \mathrm{~cm}, 20-40 \mathrm{~cm}, 40-60 \mathrm{~cm}, 60-80 \mathrm{~cm}$ e 80-100 cm). Com o intuito de estabelecer uma comparação mais efetiva da matéria orgânica de solo que recebeu ou não irrigação com efluente tratado, foram coletadas também em seis profundidades, amostras na mesma propriedade onde se encontrava o campo experimental, sob o cultivo de citrus, que é uma cultura perene. Nomearam-se CS as amostras sob cultivo de 
citrus que nunca receberam irrigação com efluente, e CC as amostras que recebiam aplicações de efluente há mais de dois anos, sem controle de dosagens.

\section{2 - COLETAS E ANÁLISES DAS AMOSTRAS DE EFLUENTE TRATADO PELO BIODIGESTOR}

O sistema biodigestor possui 5 pontos onde são feitas as coletas do efluente para realização de suas análises. Estes pontos estão representadas na Figura 28, sendo o ponto 1 correspondente ao afluente, os pontos 2,3 e 4 ao efluente em processo de tratamento anaeróbio e o ponto 5 ao efluente já tratado. $\mathrm{O}$ ponto 5 foi dividido em duas amostragens: $5 \mathrm{a}-$ Tubo de saída do efluente do biodigestor e, $5 b$ - Tanque receptor. Para a realização dos ensaios em laboratório, foram coletadas amostras nos pontos 1 e 5 . As amostragens ocorreram em diferentes períodos nos anos de 2008 e 2009.

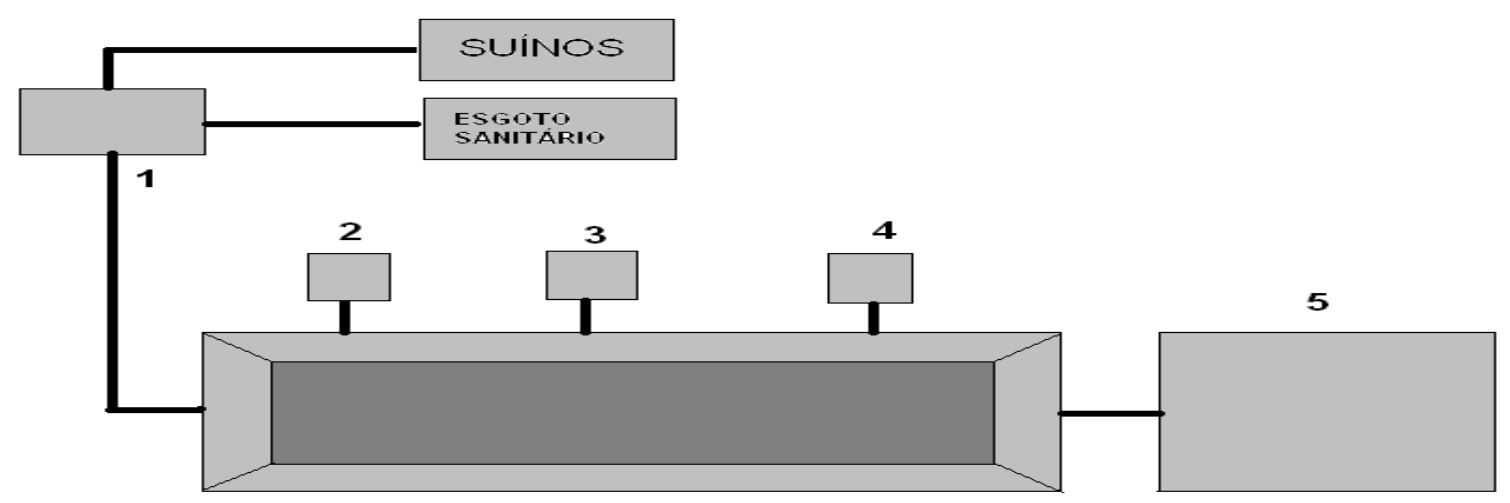

Figura 28: Esquema do biodigestor e de seus cinco pontos de coleta

Durante as coletas bimestrais de outubro de 2008 a outubro de 2009, foram determinados valores de $\mathrm{pH}$, oxigênio dissolvido, potencial redox, condutividade e temperatura utilizando-se uma Sonda Multiparâmetros WTW modelo Multi340i. As amostras levadas ao laboratório foram armazenadas em frascos separados de vidro âmbar, limpos e esterilizados. As amostras coletadas foram colocadas sob refrigeração imediatamente após a coleta e assim transportadas. Para as amostras a serem analisadas por ICP-OES, antes da refrigeração, as amostras foram acidificadas com $\mathrm{HCl}$ até $\mathrm{pH}$ igual a 1,0.

No que se refere à fertilidade, o efluente foi caracterizado em termos de quantidade de macro e micronutrientes, bem como a matéria orgânica presente. Para tais ensaios, as amostras foram analisadas via ICP-OES, nos laboratórios da Embrapa Pecuária Sudeste, com exceção do nitrogênio, que foi determinado através do método Kjedhal, no Laboratório de 
Saneamento da Universidade de São Paulo, juntamente com outros parâmetros relevantes de serem comparados com a Resolução $\mathrm{n}^{\circ} 357$ do CONAMA. As análises bacteriológicas se iniciaram em um período máximo de $24 \mathrm{~h}$ após a coleta. Os ensaios foram efetuados de acordo com a $21^{\circ}$ edição do Standard Methods (APHA, 2005).

\section{3 - AMOSTRAS DE SOLO}

\subsection{1 - AMOSTRAGEM E PREPARO DAS AMOSTRAS}

As amostras de solo foram acondicionadas em bandejas plásticas, e secas à sombra. Em seguida foi realizada a limpeza manual para retirada das raízes e restos de plantas e posteriormente passado em peneira de $0,5 \mathrm{~mm}$. A nomenclatura das amostras, a qual será utilizada ao longo de toda a discussão neste trabalho, encontra-se descrita na Tabela 3 no item 4.1.2, acrescidas das amostras CS e CC também acima mencionadas, sendo que CS correspondem às amostras sob cultivo de citrus que nunca receberam irrigação com efluente, e CC as amostras que recebiam aplicações de efluente há mais de dois anos, sem controle de dosagens.

\subsection{2 - ANÁLISES COM AS AMOSTRAS DE SOLO}

\subsubsection{1 - CONDUTIVIDADE E pH DO EXTRATO DO SOLO}

Para determinar a condutividade das amostras de solo usou-se um método desenvolvido pelo Laboratório de Salinidade dos EUA, o qual extrai sais solúveis em água com base na relação água /solo (VAN RAIJ, 2001).

Para a obtenção dos extratos, adicionou-se $100 \mathrm{~cm}^{3}$ de solo seco. Em seguida adicionou-se água até o ponto de saturação. Deixou-se em repouso por uma hora. Utilizando um funil de Buchner, filtrou-se a mistura recolhendo a solução em um frasco plástico com tampa. O condutivímetro foi calibrado com solução de $\mathrm{KCl} 0,01 \mathrm{~mol} \mathrm{~L}^{-1}$, sendo que a condutividade elétrica dessa solução é de $1,41 \mathrm{dS} \mathrm{m}^{-1}$ a $25{ }^{\circ} \mathrm{C}$. Lavou-se a célula de condutividade três vezes com água deionizada e encheu-a com o extrato do solo. Usou-se um termostato para manter a temperatura a $25{ }^{\circ} \mathrm{C}$. As medidas foram feitas em duplicata.

Para a determinação do $\mathrm{pH}$ do solo foi misturado $10 \mathrm{~cm}^{3}$ de terra fina seca ao ar (TFSA) com $25 \mathrm{~mL}$ de $\mathrm{CaCl}_{2}$ 0,01 mol L-1. As amostras foram agitadas por 15 minutos e 
deixadas em repouso durante duas horas. Em seguida, procedeu-se a leitura utilizando um eletrodo de vidro combinado. Para fins de comparação, também foram conduzidas determinações do $\mathrm{pH}$ do solo empregando-se $25 \mathrm{~mL}$ de água, em vez da solução de Cloreto de Cálcio.

\subsubsection{2 - DETERMINAÇÃO DO TEOR DE MATÉRIA ORGÂNICA POR VIA ÚMIDA E POR ANÁLISE ELEMENTAR}

Para a determinação do teor de matéria orgânica via úmida, empregou-se a metodologia sugerida por NOGUEIRA et al. (2005).

Um volume de $5 \mathrm{~mL}$ de uma solução de dicromato de potássio foi adicionada à uma massa igual a $0,5 \mathrm{~g}$ de solo já seco e peneirado, além de $10 \mathrm{~mL}$ de ácido sulfúrico concentrado. Após repouso de 30 minutos, adicionou-se $100 \mathrm{~mL}$ de água deionizada e 5 gotas de indicador ferroína. A solução foi titulada com solução de sulfato ferroso amoniacal $0,5 \mathrm{molL}^{-1}$ até o ponto de viragem, que atinge coloração de verde-turvo. As determinações foram realizadas em triplicata.

A análise elementar foi conduzida em duplicata, utilizando-se $10 \mathrm{mg}$ de solo bruto, em analisador elementar da marca Perkin Elmer, modelo 2400.

\subsubsection{3 - ESPECTROSCOPIA DE FLUORESCÊNCIA INDUZIDA POR LASER}

As medidas foram realizadas em duplicata utilizando-se o equipamento portátil para análise de Fluorescência Induzida por Laser (descrição no item 4.6.2), com amostras de solo bruto peneiradas. Os parâmetros adotados (MILORI et al., 2006) foram:

-Tempo de integração $=1200 \mathrm{~ms}$

-Boxcar: 4

-Average: 5

-Varredura entre 470 e $800 \mathrm{~nm}$.

\subsubsection{4 - ESPECTROSCOPIA NA REGIÃO DO INFRAVERMELHO PRÓXIMO}

Para a obtenção dos espectros de solos, as amostras secas e peneiradas foram analisadas em espectrômetro de infravermelho próximo, varrendo a fixa de 10000 a $4000 \mathrm{~cm}^{-1}$, 
com resolução de $16 \mathrm{~cm}^{-1}$ e acumulação de 32 varreduras por espectro. O equipamento utilizado foi um espectrômetro de infravermelho próximo com refletância difusa PerkinElmer, modelo Spectrum 100N, pertencente à Embrapa Instrumentação Agropecuária.

\section{4 - AMOSTRAS DE ÁCIDOS HÚMICOS EXTRAÍDOS DO SOLO}

\subsection{1 - EXTRAÇÃO DOS ÁCIDOS HÚMICOS DO SOLO ATRAVÉS DE FRACIONAMENTO QUÍMICO}

As substâncias húmicas (SH) do solo foram extraídas segundo SWIFT et al., (1996), partindo-se de $200 \mathrm{~g}$ de TFSA de amostra, após ter sido passada em peneira de 0,5 $\mathrm{mm}$.

$\mathrm{O}$ valor de $\mathrm{pH}$ de cada amostra foi ajustado para 1-2 com adição de $\mathrm{HCl} 1 \mathrm{~mol} \mathrm{~L}^{-1}$. O volume da solução foi ajustado com $\mathrm{HCl} 0,1 \mathrm{~mol} \mathrm{~L}^{-1}$ até atingir uma concentração final com uma relação de $10 \mathrm{~mL}$ de líquido por $1 \mathrm{~g}$ de TFSA. A solução foi agitada manualmente durante uma hora e, após deixar a solução em repouso, separou-se o sobrenadante por sifonação. O sobrenadante separado que seria utilizado para extração de ácidos fúlvicos (AF), foi descartado após neutralização.

Ao solo residual foi adicionado $\mathrm{NaOH} 0,1 \mathrm{~mol} \mathrm{~L}^{-1}$, resultando no final uma relação solo-solução 10:1. A solução foi agitada durante 4 horas. A seguir, a suspensão ficou em repouso por 16 horas e o sobrenadante foi isolado através de uma centrifugação (10000 rpm 10 min) e reservado para posterior acidificação. O material insolúvel, composto da fração mineral e humina, também foi descartado.

O sobrenadante isolado foi acidificado com $\mathrm{HCl}$ 6,0 mol L ${ }^{-1}$, com agitação simultânea até atingir pH 1,0 e mantido novamente em repouso por 16 horas. Em seguida, a solução foi centrifugada (10000 rpm - $10 \mathrm{~min}$ ) para separar o AH (precipitado) e as frações de AF, sendo que as frações de AF foram descartadas.

A fração de AH foi redissolvida através da adição de um pequeno volume conhecido de $\mathrm{KOH} 0,1 \mathrm{~mol} \mathrm{~L}^{-1}$. Adicionou-se $1,5 \mathrm{~g} \mathrm{KCl}$ sólido, atingindo uma concentração de $\mathrm{K}^{+}$de $0,3 \mathrm{~mol} \mathrm{~L}^{-1}$. Após, centrifugou-se a solução sob alta velocidade (15000 rpm - $10 \mathrm{~min}$ ) para que os sólidos suspensos fossem removidos.

$\mathrm{O}$ AH foi então reprecipitado, adicionando-se $\mathrm{HCl}$ 6,0 $\mathrm{mol} \mathrm{L}^{-1}$ com agitação simultânea até que fosse atingido pH 1,0-1,5, e após, a suspensão foi mantida em repouso por 16 horas. Centrifugou-se a solução $(10000 \mathrm{rpm}$ - $10 \mathrm{~min})$ e o sobrenadante foi então 
descartado. O precipitado $(\mathrm{AH})$ foi suspenso em solução $\mathrm{HCl} 0,1 \mathrm{~mol} \mathrm{~L} \mathrm{~L}^{-1}+\mathrm{HF}$ 0,3 mol L $\mathrm{L}^{-1}$ num recipiente plástico e agitado durante 16 horas a temperatura ambiente.

A seguir a solução foi centrifugada (10000 rpm - $10 \mathrm{~min})$ e o precipitado foi transferido para uma membrana de diálise (Spectra/Por 6000 - 8000Da), preparada segundo a metodologia de MC PHIE (1971), utilizando água deionizada. Procedeu-se a diálise contra água deionizada até que a água de diálise apresentasse teste negativo de $\mathrm{Cl}^{-}$com nitrato de prata. Para isso, tal procedimento foi mantido durante aproximadamente cinco dias, fazendose a troca da água deionizada duas vezes por dia.

Após a diálise, as amostras foram congeladas e liofilizadas e o sólido obtido (AH) foi reservado para posteriores análises.

\subsection{2 - ANÁLISES COM OS ÁCIDOS HÚMICOS EXTRAÍDOS DO SOLO}

\subsubsection{1 - ESPECTROSCOPIA NA REGIÃO DO INFRAVERMELHO MÉDIO COM TRANSFORMADA DE FOURIER}

As medidas foram feitas segundo metodologia bem conhecida na literatura (STEVENSON, 1994) utilizando um espectrofotômetro de FTIR Perkin Elmer, Paragon 1000 PC, da Embrapa Instrumentação Agropecuária. Os espectros de pastilhas das amostras dos ácidos húmicos liofilizados, preparadas com 1,0 mg de amostra e 100 mg de $\mathrm{KBr}$ (Brometo de Potássio), foram obtidos a partir de 32 varreduras, com resolução de $4 \mathrm{~cm}^{-1}$, no intervalo de 4000 a $400 \mathrm{~cm}^{-1}$. Para compressão das pastilhas foi utilizada uma pressão de 5 toneladas.

\subsubsection{2 - ESPECTROSCOPIA DE FLUORESCÊNCIA EM SOLUÇÃO: MODALIDADES DE EMISSÃO E SINCRONIZADA}

Soluções estoque de 200 ppm foram preparadas dissolvendo-se 2,0 mg de AH em 10,0 $\mathrm{mL}$ de solução de $\mathrm{NaHCO}_{3}$. Em seguida, a partir destas, foram preparadas soluções de concentração 20 ppm, sendo que o pH da solução resultante ficou em torno de 8 . As amostras foram colocadas em cubeta de quartzo multifacetada com tampa de teflon e analisadas a temperatura ambiente utilizando um espectrômetro de luminescência Perkin Elmer LS50B pertencente a Embrapa Instrumentação Agropecuária. As análises foram feitas em duplicatas. 
Os espectros de fluorescência foram adquiridos nos modos de emissão e varredura sincronizada, segundo as metodologias propostas por MILORI et al., (2002) e KALBITZ et al., (2000).

a) Modalidade de Emissão

Na metodologia proposta por MILORI et al., (2002), foram obtidos os espectros de emissão com excitação em $465 \mathrm{~nm}$, intervalo de varredura entre 480 e $700 \mathrm{~nm}$ e com filtro aberto. $\mathrm{O}$ índice de humificação denominado $\mathrm{A}_{465}$ foi determinado a partir da integral da região total dos espectros de emissão das amostras com comprimento de onda de excitação $\lambda_{\mathrm{exc}}=465 \mathrm{~nm}$.

b) Modalidade de Sincronizada

Utilizando a metodologia de KALBITZ et al., (2000), foram obtidos espectros de varredura sincronizada entre 300 e $520 \mathrm{~nm}$ simultaneamente com excitação e emissão com filtro aberto e diferença de comprimento de onda $\Delta \lambda=55 \mathrm{~nm}$ para as amostras de ácidos húmicos extraídos do solo. A determinação do índice de humificação foi feita a partir da razão entre as intensidades de fluorescência em 456 e $374 \mathrm{~nm}$.

\subsubsection{3 - MEDIDA DE TAMANHO DE PARTÍCULAS E POTENCIAL ZETA}

Tanto as medidas de tamanho de partículas quanto as determinações do potencial Zeta foram conduzidas utilizando-se o equipamento Zetasizer Nano, da marca Malvern, pertencente à Embrapa Instrumentação Agropecuária.

As soluções eram preparadas no instante da realização das medidas. O AH era macerado e pesado e recebia adição de Cloreto de Potássio quando requerido, completando-se o volume com água deionizada. Posteriormente, as soluções tinham o valor de $\mathrm{pH}$ do meio ajustado e eram sonicadas em ponteira ultrassônica por 5 minutos em banho de gelo. Para as determinações de potencial Zeta e tamanho de partículas, adicionava-se cerca de $4 \mathrm{~mL}$ da solução em cela específica com auxílio de uma seringa. Após inseridas no equipamento, as medidas eram conduzidas em triplicata, para os valores de $\mathrm{pH}$ iguais a 2, 7 e 12, utilizando-se 50 varreduras para cada medida. O equipamento operava em modo de Smoluchowski.

Para melhor desempenho do equipamento, estabeleceu-se que as concentrações de $\mathrm{AH}$ estudadas seriam de 100 e $200 \mathrm{mg} \mathrm{L}^{-1}$. As concentrações de $\mathrm{KCl}$ corresponderam às mesmas utilizadas nos estudos de SIMÕES (2005). Os valores de pH utilizados no planejamento experimental foram iguais a 2 e 12, realizando-se também medidas em valor de $\mathrm{pH}$ igual a 7. 
Medindo-se nesses valores, pretendia-se verificar o comportamento das amostras sem ionização dos compostos (valor de $\mathrm{pH}$ igual a 2), com ionização parcial dos compostos grupos carboxílicos - (valor de pH igual a 7) e com ionização total dos compostos - grupos carboxílicos e fenólicos -, em valor de ph igual a 12 (PICCOLO et al., 2002).

Uma investigação sobre a seleção de variáveis mais significativas tanto para o estudo das medidas de tamanho de partículas, como para medidas de potencial Zeta foi conduzida de acordo com um planejamento fatorial $2^{3}$, cujas variáveis estudadas foram (1) concentração iônica, empregando-se Cloreto de Potássio, (2) concentração de ácido húmico e (3) pH. Tais variáveis foram estudadas nos seguintes níveis, conforme mostra a Tabela 5.

Tabela 5.: Variáveis de estudo e níveis investigados do menor (-) para maior (+):

\begin{tabular}{cccc}
\hline Nível & $\begin{array}{c}\text { Concentração } \\
\text { de KCl } \\
\left(\mathbf{m o l ~ L}^{-1}\right)\end{array}$ & $\begin{array}{c}\text { Concentração } \\
\text { de AH } \\
\left(\mathbf{m g ~ L}^{-1}\right)\end{array}$ & $\mathbf{p H}$ \\
\hline $\mathbf{1}$ & 0,05 & 100 & 2 \\
$\mathbf{- 1}$ & 0,5 & 200 & 12 \\
\hline
\end{tabular}

Sendo um planejamento $2^{3}$, foram conduzidos 8 experimentos, para medidas de tamanho de partículas e medidas de potencial Zeta, cujas características de execução são mostradas na Tabela 6 .

Tabela 6: Relação dos experimentos conduzidos e suas condições :

\begin{tabular}{cccc}
\hline & \multicolumn{3}{c}{ Condições } \\
\hline Experimento & Conc. KCl & Conc. AH & pH \\
\hline $\mathbf{1}$ & -1 & -1 & -1 \\
$\mathbf{2}$ & -1 & -1 & 1 \\
$\mathbf{3}$ & -1 & 1 & -1 \\
$\mathbf{4}$ & -1 & 1 & 1 \\
$\mathbf{5}$ & 1 & -1 & -1 \\
$\mathbf{6}$ & 1 & -1 & 1 \\
$\mathbf{7}$ & 1 & 1 & -1 \\
$\mathbf{8}$ & 1 & 1 & 1 \\
\hline
\end{tabular}

De acordo com a teoria estatística de planejamentos experimentais, o efeito de um fator, denotado como "A", sobre uma dada resposta em estudo é definido como a diferença entre o valor médio da resposta no nível superior e o valor médio da resposta no nível inferior 
desse fator (BRUMS et al., 2006). Assim sendo, os efeitos principais (EP) foram calculados de acordo com a equação 6:

$$
E P(A)=\bar{y}(A+)-\bar{y}(A-)
$$

Onde: $\operatorname{EP}(\mathrm{A})$ representa o efeito principal do fator $\mathrm{A} ; \bar{y}(A+)$ é a média da respostas observadas no nível mais alto do fator $(\mathrm{A}+)$ e $\bar{y}(A-)$ é a média da respostas observadas no nível mais baixo do fator (A-).

Para julgar a significância dos fatores e seus respectivos efeitos foi utilizado o método gráfico que se baseia na noção de probabilidade cumulativa e no teorema do limite central. Este método consiste em assumir que os efeitos calculados a partir de um planejamento experimental são normalmente distribuídos com média igual ao próprio efeito. Sob a hipótese nula de que todos os efeitos são iguais a zero, a média de todos os efeitos deve refletir apenas os erros aleatórios envolvidos na execução experimental.

Dessa forma, construindo-se o gráfico dos efeitos em ordem crescente contra os respectivos valores de probabilidade normal (z scores), de acordo com a função de probabilidade cumulativa, o perfil resultante será uma linha reta. $\mathrm{O}$ gráfico de probabilidade normal testará se os efeitos calculados têm a mesma distribuição (com média populacional igual a zero). Então se a média de um efeito não for zero, seu ponto correspondente apresentará um desvio com relação à linha reta.

Como regra, quanto maior este desvio, mais significativo será o efeito. Para efeitos positivos, os pontos correspondentes cairão acima da linha reta, enquanto aqueles para os efeitos negativos cairão abaixo da linha reta (BRUMS et al., 2006). 


\section{CAPÍTULO 5 - RESULTADOS E DISCUSSÃO}

\section{1 - O EFLUENTE}

\subsection{1 - PARÂMETROS FÍSICO-QUÍMICOS E ENSAIOS MICROBIOLÓGICOS}

As Tabelas 7 a 11 apresentam os resultados das análises físico-químicas determinadas in situ. No período investigado, observou-se que a variação de temperatura nos momentos de coleta foi de $20,0^{\circ} \mathrm{C}$ a $31,0^{\circ} \mathrm{C}$, sendo as temperaturas bastante similares entre os diferentes pontos de amostragem do sistema. $\mathrm{O}$ pH em cada ponto de coleta manteve-se na faixa de aproximadamente 7 , sendo esse valor propício ao crescimento de microorganismos que degradam a matéria orgânica na ausência de oxigênio. Os resultados de oxigênio dissolvido (geralmente menores que $\left.1 \mathrm{mg} \mathrm{L}^{-1}\right)$ e potencial redox $(\leq 0 \mathrm{mV})$ apresentam-se dentro do esperado para um sistema anaeróbio. Os valores da condutividade elétrica foram os resultados que apresentaram maior variação nas diferentes análises, com valor mínimo de 2,06 até máximo de $4,87 \mathrm{mS} \mathrm{cm}^{-1}$, e um aumento pronunciado no mês de agosto de 2009 . A condutividade elétrica confere certo grau de salinidade presente no efluente, podendo este ser classificado por este parâmetro como "água salobra”, o que limita sua utilização em irrigação agrícola, mas não o seu uso como fertilizante, desde que controlado (BIEROLAI et al., 1984; ZUQUETTE et al., 1993). Com exceção da temperatura, não foram observadas variações nos parâmetros em função do período do ano (DA SILVA et al 2010, submetido).

Tabela 7 - Temperatura $\left({ }^{\circ} \mathrm{C}\right)$ da solução nos diferentes pontos de amostragem e em diferentes períodos do ano.

Momento da Amostragem

\begin{tabular}{cccccccc}
\hline $\begin{array}{c}\text { Ponto de } \\
\text { Coleta }\end{array}$ & Out/08 & Dez/08 & Fev/09 & Abr/09 & Jun/09 & Ago/09 & Out/09 \\
\hline 1 & 31,0 & 27,0 & 26,8 & 29,1 & 20,0 & 21,2 & 25,2 \\
2 & 30,0 & 26,3 & 28,7 & 26,0 & 20,6 & 24,1 & 25,3 \\
3 & 30,0 & 26,1 & 28,3 & 25,9 & 20,4 & 23,9 & 24,8 \\
4 & 29,5 & 26,0 & 29,0 & 25,6 & 20,2 & 23,7 & 26,3 \\
$5 \mathrm{a}$ & 28,3 & - & 27,8 & 26,1 & 21,3 & 26,9 & 25,2 \\
$5 \mathrm{~b}$ & 30,5 & 24,4 & 28,2 & 27,2 & 21,0 & 23,1 & 24,6 \\
\hline
\end{tabular}


Tabela 8 - pH da solução nos diferentes pontos de amostragem e em diferentes períodos do ano.

Momento da Amostragem

\begin{tabular}{cccccccc}
\hline $\begin{array}{c}\text { Ponto de } \\
\text { Coleta }\end{array}$ & Out/08 & Dez/08 & Fev/09 & Abr/09 & Jun/09 & Ago/09 & Out/09 \\
\hline 1 & 7,1 & 6,3 & 6,1 & 6,2 & 6,8 & 7,1 & 5,9 \\
2 & 7,0 & 6,8 & 6,7 & 6,8 & 6,8 & 6,8 & 6,7 \\
3 & 7,0 & 6,8 & 6,7 & 6,8 & 6,8 & 6,8 & 6,7 \\
4 & 7,0 & 6,8 & 6,7 & 6,8 & 6,8 & 6,8 & 6,7 \\
$5 \mathrm{a}$ & 7,0 & - & 6,9 & 6,9 & 7,0 & 6,8 & 6,8 \\
$5 \mathrm{~b}$ & 7,2 & 7,3 & 7,1 & 7,2 & 6,9 & 7,1 & 7,2 \\
\hline
\end{tabular}

Tabela 9 - Oxigênio Dissolvido $\left(\mathrm{mg} \mathrm{L}^{-1}\right)$ da solução nos diferentes pontos de amostragem e em diferentes períodos do ano.

Momento da Amostragem

\begin{tabular}{cccccccc}
\hline $\begin{array}{c}\text { Ponto de } \\
\text { Coleta }\end{array}$ & Out/08 & Dez/08 & Fev/09 & Abr/09 & Jun/09 & Ago/09 & Out/09 \\
\hline 1 & 0,29 & 0,08 & 0,70 & 0,30 & 3,30 & 4,00 & 6,88 \\
2 & 0,30 & 0,05 & 0,63 & 0,56 & 0,68 & 0,11 & 0,44 \\
3 & 0,15 & 0,06 & 0,30 & 0,50 & 0,84 & 0,07 & 0,35 \\
4 & 0,30 & 0,05 & 0,70 & 0,50 & 0,50 & 0,09 & 0,30 \\
$5 \mathrm{a}$ & 0,30 & - & 0,53 & 0,50 & 0,60 & 0,08 & 0,30 \\
$5 \mathrm{~b}$ & 0,27 & 0,15 & 1,13 & 1,08 & 0,68 & 0,13 & 0,90 \\
\hline
\end{tabular}


Tabela 10 - Potencial redox $(\mathrm{mV})$ da solução nos diferentes pontos de amostragem e em diferentes períodos do ano.

Momento da Amostragem

\begin{tabular}{cccccccc}
\hline $\begin{array}{c}\text { Ponto de } \\
\text { Coleta }\end{array}$ & Out/08 & Dez/08 & Fev/09 & Abr/09 & Jun/09 & Ago/09 & Out/09 \\
\hline 1 & -11 & 23 & 34 & 26 & -2 & -24 & 48 \\
2 & 0 & -6 & -1 & -8 & -4 & -8 & -2 \\
3 & 0 & -9 & 0 & -8 & -3 & -7 & -2 \\
4 & 0 & -9 & -2 & -7 & -4 & -9 & -3 \\
$5 a$ & 0 & - & -12 & -12 & -13 & -5 & -6 \\
$5 b$ & -10 & -37 & -25 & -2 & -13 & -25 & -34 \\
\hline
\end{tabular}

Tabela 11 - Condutividade Elétrica $\left(\mathrm{mS} \mathrm{cm}^{-1}\right)$ da solução nos diferentes pontos de amostragem e em diferentes períodos do ano.

Momento da Amostragem

\begin{tabular}{cccccccc}
\hline $\begin{array}{c}\text { Ponto de } \\
\text { Coleta }\end{array}$ & Out/08 & Dez/08 & Fev/09 & Abr/09 & Jun/09 & Ago/09 & Out/09 \\
\hline 1 & 3,24 & 2,12 & 3,97 & 2,06 & 2,24 & 2,55 & 2,59 \\
2 & 3,60 & 4,46 & 2,87 & 3,68 & 3,34 & 4,84 & 2,46 \\
3 & 3,68 & 4,52 & 2,88 & 3,76 & 3,78 & 4,81 & 2,53 \\
4 & 3,58 & 4,47 & 2,83 & 3,65 & 3,77 & 4,87 & 2,53 \\
$5 \mathrm{a}$ & 3,63 & - & 2,89 & 3,64 & 3,76 & 4,52 & 2,50 \\
$5 \mathrm{~b}$ & 3,58 & 4,23 & 2,91 & 3,62 & 3,74 & 4,63 & 2,62 \\
\hline
\end{tabular}

Um resultado representativo das análises microbiológicas e físico-químicas do afluente e do efluente encontram-se na Tabela 12. Houve uma redução bastante expressiva quanto às taxas de DQO e DBO de aproximadamente $97 \%$ e 96\%, respectivamente, assim como E. coli que apresentou uma redução de $99,99 \%$, sendo muito significante do ponto de vista de redução de patógenos, porém ainda não alcançando um valor absoluto adequado para lançamento direto em corpos d'água (CONAMA, 2005). A proposta de utilizar o efluente no solo como componente para fertirrigação, proporciona um tratamento terciário do efluente, 
pela capacidade depurante que o solo possui (KUNZ et al., 2009). Os pontos 5a e 5b podem diferir discretamente em alguns parâmetros, principalmente sólidos suspensos, provavelmente devido ao crescimento de algumas algas e poeira no tanque de armazenamento.

Tabela 12: Resultado das análises físico-químicas e microbiológicas do efluente na entrada e saída do biodigestor (análise realizada em 19/11/2008).

\begin{tabular}{|c|c|c|c|}
\hline 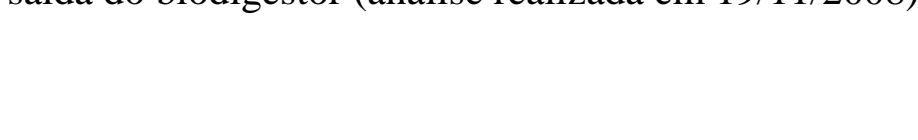 & $\begin{array}{c}\text { PONTO } \\
1\end{array}$ & PONTO 5a & PONTO 5b \\
\hline $\mathrm{pH}$ & 6,0 & 7,0 & 7,3 \\
\hline DEMANDA QUÍMICA DE OXIGÊNIO $\left(\mathrm{mg} \mathrm{O}_{2} \mathrm{~L}^{-1}\right)$ & 13160 & 366 & 296 \\
\hline $\begin{array}{l}\text { DEMANDA BIOQUÍMICA DE OXIGÊNIO } \\
\qquad\left(\mathrm{mg} \mathrm{O}_{2} \mathrm{~L}^{-1}\right)\end{array}$ & 8594 & 209 & 186 \\
\hline NITROGÊNIO NITRATO $\left(\mathrm{mg} \mathrm{L}^{-1}\right)$ & 19,17 & 1,63 & 1,65 \\
\hline NITROGÊNIO NITRITO $\left(\mathrm{mg} \mathrm{L}^{-1}\right)$ & $<0,001$ & $<0,001$ & $<0,001$ \\
\hline NITROGÊNIO AMONIACAL $\left(\mathrm{mg} \mathrm{L}^{-1}\right)$ & 337 & 443 & 402 \\
\hline NITROGÊNIO KJELDHAL $\left(\mathrm{mg} \mathrm{L}^{-1}\right)$ & 1067 & 619 & 694 \\
\hline FOSFATO TOTAL $\left(\mathrm{mg} \mathrm{L}^{-1}\right)$ & 208 & 83 & 61 \\
\hline ÓLEOS E GRAXAS $\left(\mathrm{mg} \mathrm{L}^{-1}\right)$ & 394 & 72 & 76 \\
\hline COLIFORMES TOTAIS (UFC* / 100mL) & $5,710^{12}$ & $4,710^{8}$ & $2,310^{8}$ \\
\hline E. coli $\left(\mathrm{UFC}^{*} / 100 \mathrm{~mL}\right)$ & $2,110^{10}$ & $1,010^{6}$ & $2,010^{5}$ \\
\hline SÓLIDOS SEDIMENTÁVEIS (mg L ${ }^{-1}$ ) & 120,0 & 0,7 & 7,0 \\
\hline SÓLIDOS SUSPENSOS TOTAIS (mg L $\left.{ }^{-1}\right)$ & 8335 & 144 & 214 \\
\hline SÓLIDOS SUSPENSOS FIXOS $\left(\mathrm{mg} \mathrm{L}^{-1}\right)$ & 1968 & 16 & 98 \\
\hline SÓLIDOS SUSPENSOS VOLÁTEIS (mg L ${ }^{-1}$ ) & 6367 & 128 & 116 \\
\hline
\end{tabular}

* Unidade Formadora de Colônia

\subsection{2 - CONCENTRAÇÃO DE MACRO E MICRONUTRIENTES}

A Tabela 13 apresenta as concentrações médias dos elementos, bem como os valores máximos e mínimos encontrados. O nutriente mais abundante é o nitrogênio, na forma amoniacal, com quantidades apreciáveis de potássio, cálcio, fósforo e magnésio. Estes elementos possuem facilidade na retenção no solo, entretanto podem também se apresentar sob forma solúvel e lixiviável no solo, fato que deve ser levado em conta para evitar contaminação de águas subterrâneas. Pelos resultados apresentados, pode-se observar que os 
valores de concentração dos elementos variam significativamente, podendo o valor máximo para alguns elementos ser superior ao dobro do valor mínimo. Este fato dificulta a aplicação do efluente como fertilizante, já que torna difícil uma dosagem precisa do nutriente. Outro ponto que deve ser destacado é a presença de sódio em concentração que merece atenção. $\mathrm{O}$ uso intensivo de águas contendo grande quantidade de sódio pode produzir a salinização do solo, onde colóides orgânicos e inorgânicos (com maior ênfase) podem ser desestabilizados, diminuindo a fertilidade desse (ALMEIDA, 2009). Fica claro que o uso do efluente tratado pelo biodigestor deve ser utilizado de forma controlada, para que se evite algum tipo de impacto negativo no solo (DA SILVA, et al, 2010, submetido).

Tabela 13: Elementos de interesse presentes no efluente tratado (ponto 5). Os valores correspondem a 5 coletas diferentes ocorridas entre junho de 2008 e março de 2009.

\begin{tabular}{cccc}
\hline & \multicolumn{3}{c}{ Valores $\left(\mathrm{mg} \mathrm{L}^{-1}\right)$} \\
\cline { 2 - 4 } Elemento $^{*}$ & Média & Mínimo & Máximo \\
\cline { 2 - 4 } $\mathrm{N}$ & 298 & 226 & 390 \\
$\mathrm{P}$ & 50,60 & 38,6 & 70,96 \\
$\mathrm{~K}$ & 116,64 & 90,53 & 164,20 \\
$\mathrm{Ca}$ & 76,11 & 62,95 & 97,86 \\
$\mathrm{Mg}$ & 29,63 & 24,75 & 37,58 \\
$\mathrm{~S}$ & 3,78 & 2,46 & 5,51 \\
$\mathrm{Cu}$ & 0,08 & 0,03 & 0,14 \\
$\mathrm{Fe}$ & 1,01 & 0,48 & 1,67 \\
$\mathrm{Mn}$ & 0,32 & 0,26 & 0,40 \\
$\mathrm{Zn}$ & 0,22 & 0,11 & 0,36 \\
$\mathrm{Sr}$ & 0,43 & 0,31 & 0,61 \\
$\mathrm{~V}$ & 0,10 & 0,01 & 0,24 \\
$\mathrm{Na}$ & 117,06 & 81,30 & 161,67 \\
$\mathrm{Ba}$ & 0,30 & 0,05 & 0,85 \\
$\mathrm{Al}$ & 0,54 & 0,35 & 0,78 \\
\hline
\end{tabular}

*Nitrogênio determinado por método Kjeldhal. Outros elementos por ICP-OES. 


\subsection{1 - CONDUTIVIDADE E $\mathrm{pH}$}

A Figura 29 apresenta os gráficos com valores obtidos de $\mathrm{pH}$ medidos em água e em solução de cloreto de cálcio, para as seis profundidades estudadas nos diferentes tratamentos. Com base nos gráficos, observa-se que os valores de $\mathrm{pH}$ variaram entre 5,5 e 7,5, sendo que as análises conduzidas em solução de cloreto de cálcio apresentaram em geral, valores inferiores aos obtidos quando as medidas foram feitas em água. Esse comportamento, conforme menciona (VAN RAIJ et al., 2001), é esperado, uma vez que a leitura do pH em solução de cloreto de cálcio propicia a leitura da acidez ativa e da acidez potencial da solução, ocasionada pela desestabilização coloidal do meio, liberando íons hidroxônio anteriormente ligados à íons $\mathrm{Al}^{3+}$. 

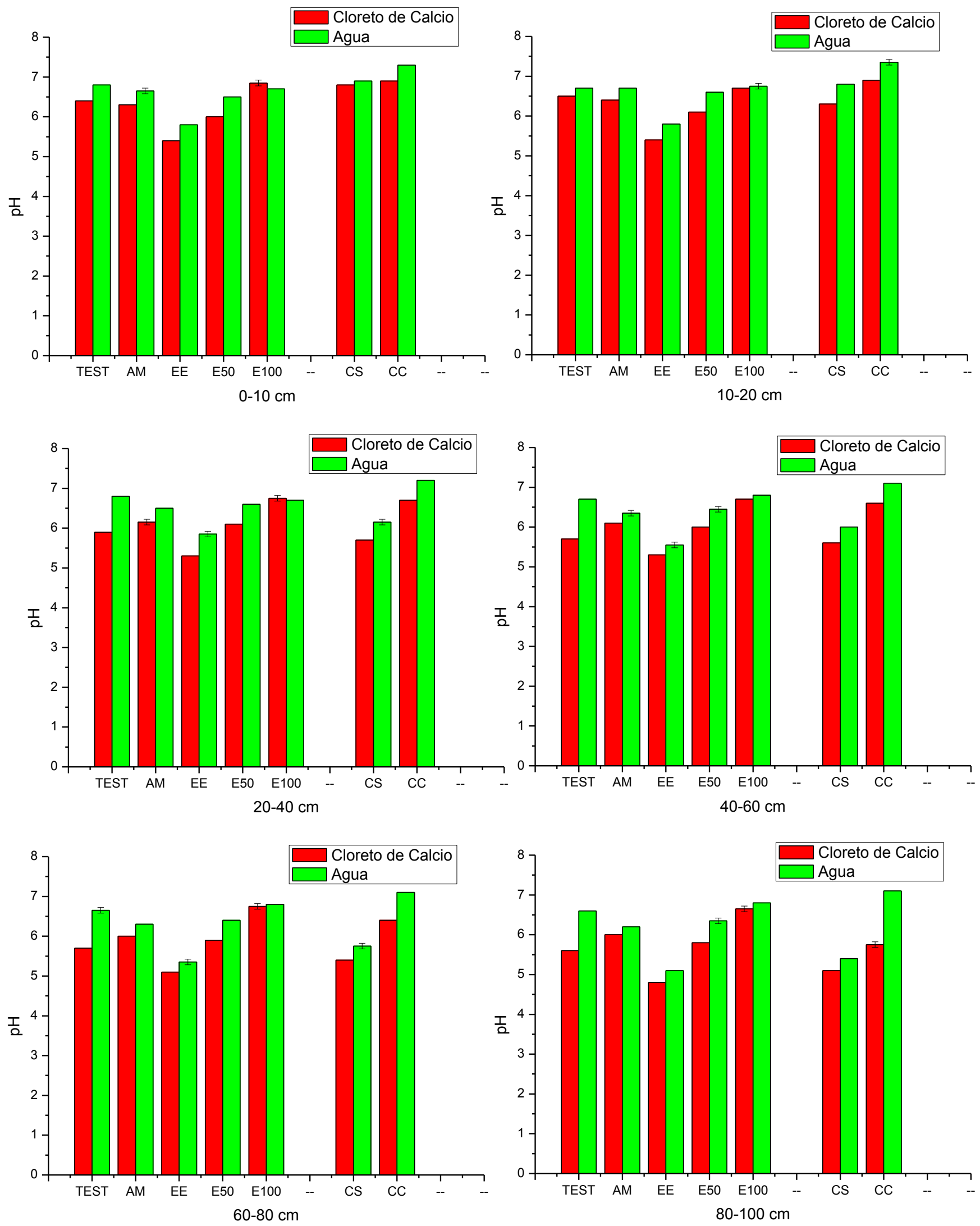

Figura 29: Valores de pH obtidos em água e em solução de Cloreto de Cálcio para as amostras de solo em tratamentos diferentes e nas profundidades estudadas.

Os valores não apresentaram alterações significativas ao longo das profundidades estudadas. As amostras TEST, de adubação mineral convencional (AM) e CS obtiveram comportamento semelhante. Para as amostras que receberam aplicações do efluente, observou-se ligeiro aumento do valor de $\mathrm{pH}$ conforme aumentou-se a dosagem do efluente. 
As amostras EE e E50 obtiveram valores em geral inferiores aos demais. Isso pode ter ocorrido em decorrência da atividade microbiana, através do processo de nitrificação onde o amônio é oxidado a nitrito e nitrato, com a produção líquida de dois íons $\mathrm{H}^{+}$e conseqüente redução do pH (YAN et al, 1996).

STAMAATIADIS et al. (1999) verificaram uma queda de 0,4 unidades no $\mathrm{pH}$ do solo que havia recebido lodo em relação ao solo controle (branco). Os autores também atribuíram esta queda ao processo de nitrificação do amônio. Pode-se dizer também, que a dosagem $100 \%$ superior de efluente (E100) não apresentou o mesmo comportamento de queda no $\mathrm{pH}$ por conta do elevado volume de água presente, tornando o material mais facilmente lixiviado ao longo do perfil do solo.

As amostras de CC mostraram sutil aumento no valor de $\mathrm{pH}$, quando comparadas aos demais tratamentos. Segundo YAN et al., (1996) a adição de resíduos orgânicos pode ocasionar aumento no $\mathrm{pH}$ do solo devido, principalmente a dois diferentes processos: descarboxilação de ânions orgânicos consumindo $\mathrm{H}^{+}$e liberando $\mathrm{CO}_{2}\left(\mathrm{R}-\mathrm{CO}-\mathrm{COO}^{-}+\mathrm{H}^{+} \rightarrow\right.$ $\mathrm{R}-\mathrm{CHO}+\mathrm{CO}_{2}$ ) e desaminação de aminoácidos. Porém, a contribuição deste último processo é provavelmente de menor importância, pelo fato de o grupo aminoácido encontrar-se predominantemente protonado.

Na Figura 30 estão apresentados os comportamentos das amostras na determinação de condutividade. Esta análise está relacionada com o conteúdo de sais na solução do solo. Podese observar um decréscimo nesse conteúdo conforme aumenta a profundidade no solo. Dentre os solos analisados, os pertencentes às amostras TEST e AM, apesar da sutil variação entre eles, não foi constatado um valor de condutividade expressivo, situando-se assim na faixa entre 132 e $187 \mu \mathrm{S} \mathrm{cm}^{-1}$. Para todas as profundidades foi observado um incremento na condutividade elétrica conforme a dosagem do efluente foi aumentada, compreendendo a faixa de $20 \mu \mathrm{S} \mathrm{cm}^{-1}$ para EE na camada de $80-100 \mathrm{~cm}_{\text {à }} 139 \mu \mathrm{S} \mathrm{cm}^{-1}$ para E100 na camada 0$10 \mathrm{~cm}$. 

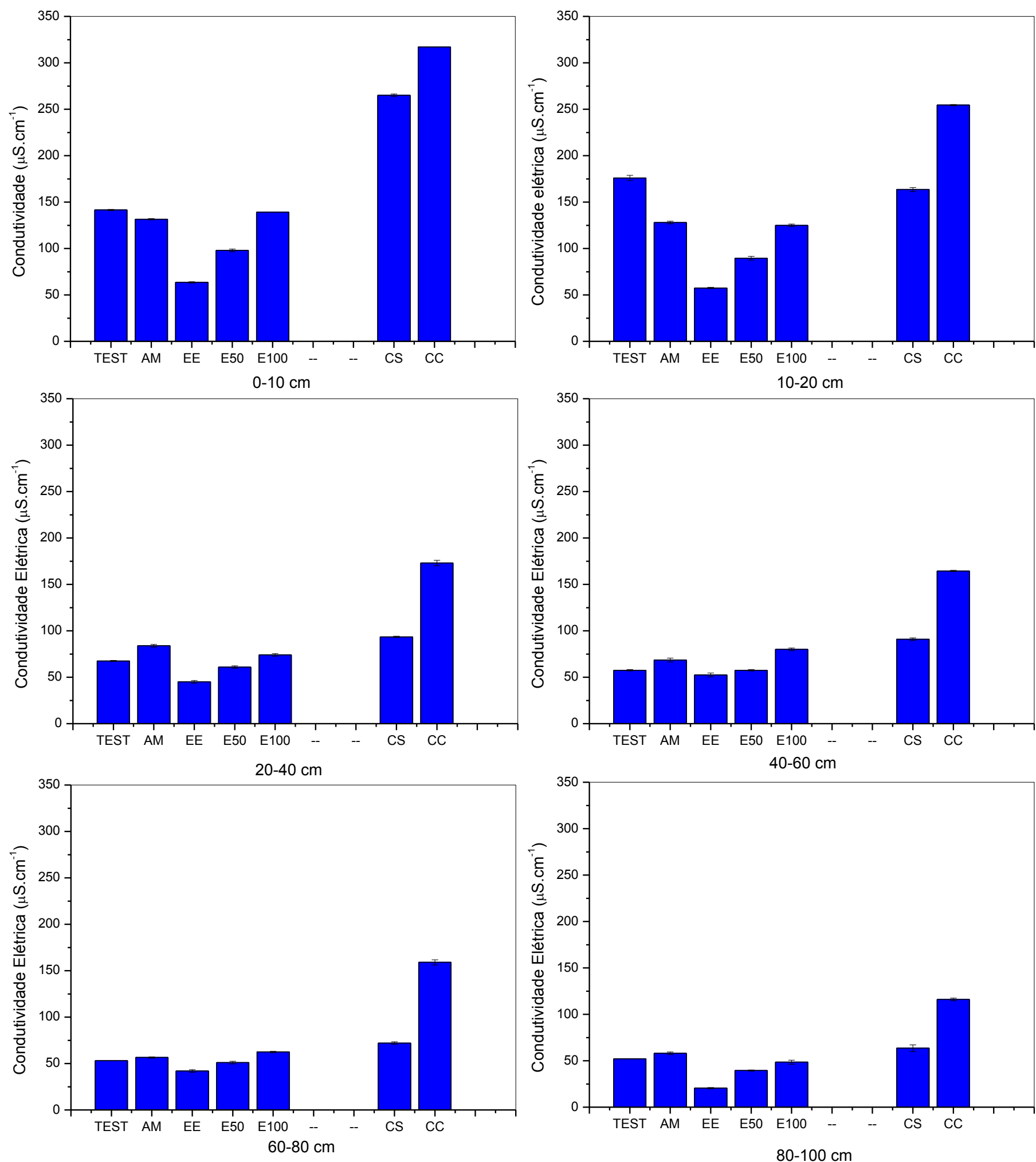

Figura 30: Valores de condutividade $\left(\mathrm{em} \mu \mathrm{S} \mathrm{cm}^{-1}\right)$ obtidos para as amostras nos diferentes tratamentos e profundidades. 
Contudo, as amostras que receberam efluente (EE, E50 e E100) apresentaram-se com valores de condutividade inferiores às amostras AM e TEST. Este fato pode ter sido ocasionado por algum possível erro no momento de amostragem, ou ainda, por uma provável lixiviação de nutrientes em decorrência da elevada ocorrência de chuvas ao longo do experimento.

O valor de condutividade de CS em relação aos demais, exceto em relação a CC pode ter ocorrido devido à peculiaridades da cultura ou do próprio local de plantio. Em relação à amostra CC, na camada de solo de $0-10 \mathrm{~cm}$, todas as profundidades evidenciaram valores de condutividade superiores aos demais. Na camada de $80-100 \mathrm{~cm}$, a condutividade atingida foi de $116 \mu \mathrm{S} \mathrm{cm} \mathrm{cm}^{-1}$, enquanto que na camada $0-10 \mathrm{~cm}$ este valor chegou a $317 \mu \mathrm{S} \mathrm{cm}^{-1}$. Tal aumento se deveu, possivelmente, à aplicação do efluente sem controle de dosagem e por um período de tempo maior em relação às amostras do plantio de sorgo. Este valor, segundo (TOMÉ Jr., 1997), encontra-se na faixa onde os efeitos da salinidade são geralmente negligenciáveis.

Cabe relembrar que o efeito de salinização caracteriza-se pela presença de altas concentrações de sódio na água de irrigação e isto pode dificultar a agregação do solo e o seu endurecimento, podendo também ser tóxico às plantas visto que a presença de sais atua no potencial osmótico afetando a capacidade de absorção d'água pelas raízes. Além disso, pode acarretar a perda de permeabilidade no solo pela adsorção dos íons de sódio às partículas do solo, as quais geralmente acumulam-se nas primeiras camadas do solo (ALMEIDA, 2009). 


\subsection{2 - DETERMINAÇÃO DO TEOR DE MATÉRIA ORGÂNICA VIA ÚMIDA E POR ANÁLISE ELEMENTAR}

Na Figura 31 podem ser observados os teores de matéria orgânica obtidos por análise elementar e por via úmida para as amostras dos diferentes tratamentos e profundidades de 0$10 \mathrm{~cm}$ e de $80-100 \mathrm{~cm}$.
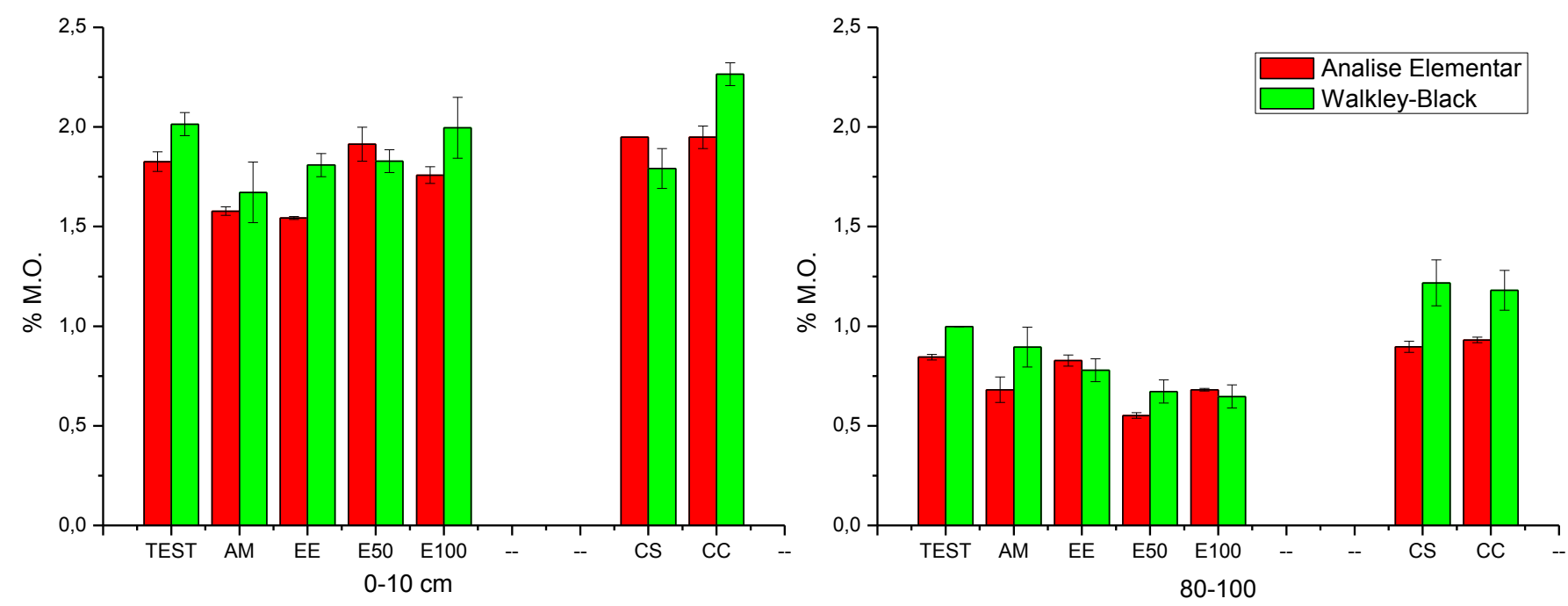

Figura 31: Teores de matéria orgânica obtidos para as amostras nas profundidades de 0-10 cm e 80-100 cm

Corroborando com (LEITE et al., 2004), os resultados obtidos para os teores de carbono apresentaram maiores concentrações na camada superficial $(0-10 \mathrm{~cm})$, e diminuem ao longo da profundidade.

Não houve uma tendência clara e expressiva para os teores de carbono variando-se os tratamentos, que apresentaram comportamentos semelhantes. Contudo, a elevação e posterior manutenção de teores elevados de carbono no solo dependerá de aplicações sucessivas do resíduo (OLIVEIRA et al., 2002), visto que os efeitos sobre os teores de carbono podem ser temporários (MELO et al., 1994) em decorrência da decomposição da matéria orgânica. Um sutil aumento no teor de carbono foi observado para as amostras CC, comparando-se com os demais tratamentos. Tal fato pode ter ocorrido por conta do maior tempo de aplicação do efluente naquela área. Quando comparados a CS, entretanto, os teores de CC mostram-se de similar comportamento. Cabe ressaltar que o experimento de campo foi conduzido por um período de tempo relativamente curto (5 meses), não estabelecendo ainda, possivelmente, um equilíbrio no ambiente do solo, em relação ao aporte de matéria orgânica proveniente do efluente. Além disso, o alto índice de chuvas no período e a elevada solubilidade dos nutrientes presentes no efluente podem ter contribuído para a lixiviação do material aportado.

\subsection{3 - ESPECTROSCOPIA NA REGIÃO DO INFRAVERMELHO PRÓXIMO}


Uma vez que os espectros de NIRS apresentam diversas harmônicas e bandas sobrepostas, visualmente não foi possível estabelecer uma diferenciação comparando-se as amostras estudadas nas seis profundidades e nos tratamentos.

Por isso, pretendeu-se utilizar os valores de absorbância obtidos nas leituras das amostras (espectros tratados com a primeira derivada) e empregando-se o software disponível no equipamento (Spectrum Quant+®) e uma propriedade do solo (teor de carbono), obteve-se um modelo, com o intuito de, em estudos futuros, empregá-lo na quantificação de carbono a partir dos dados obtidos pelos espectros. O software realiza uma análise multivariada e estabelece um modelo de calibração com as amostras selecionadas. A correlação do modelo para todas as amostras de estudo pode ser visualizada na Figura 32.

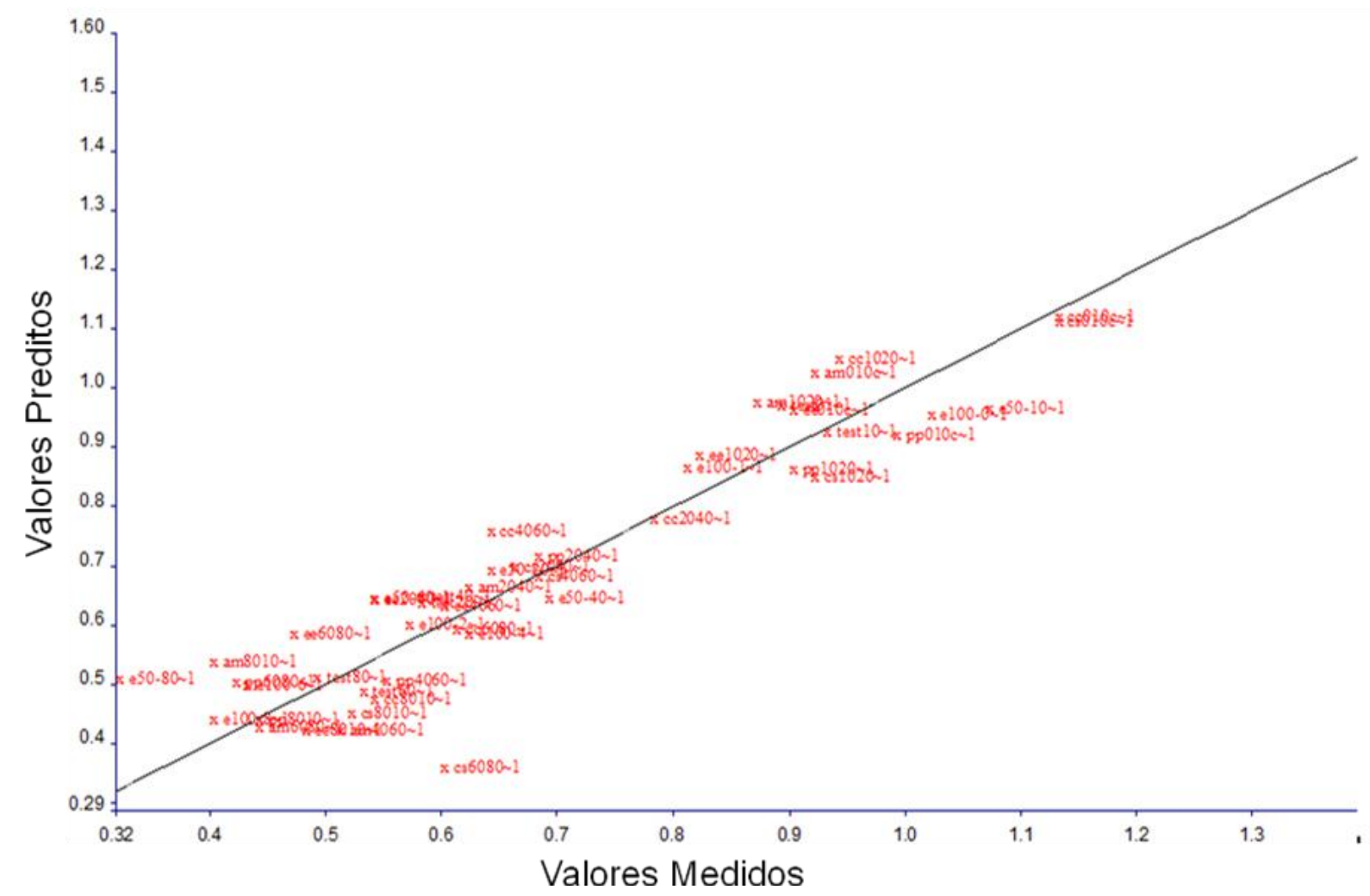

Figura 32: Gráfico dos valores de teor de carbono preditos vs medidos para as amostras de solo estudadas.

Observa-se na Figura 32 que a análise multivariada empregada foi satisfatória na obtenção do modelo de calibração, atingindo boa correlação. Foram selecionadas 3 componentes principais, obtendo-se uma variância de 82,94\%. Para uma melhora e maior exatidão do modelo, entretanto, torna-se necessária a expansão com outras amostras de solo, de características semelhantes ou não.

Recentemente, técnicas de refletância difusa usando diferentes regiões da radiação eletromagnética têm ganhado muita atenção, ampliando sua aplicação na quantificação de 
componentes de solos, como carbono total (CT) (MCCARTY et al., 2002), carbono orgânico (COT) (MADARI et al., 2005, 2006a), carbono inorgânico (MCCARTY et al., 2002; CHANG; LAIRD, 2002) e carbono microbiano (CMIC) (MCCARTY, 2001; JANIK et al., 1998).

A relevância, entre outros aspectos, da construção de modelos de calibração visando quantificação de propriedades do solo, como teor de carbono sustenta-se no fato de que, ao contrário das análises químicas convencionais, esta análise espectroscópica não requer consumo de reagentes.

Vários trabalhos publicados (CHANG et al., 2001; LUDWIG et al., 2002; COÛTEAUX et al., 2003; MADARI et al., 2005; MADARI et al., 2006; VISCARRAROSSEL et al., 2006) que tiveram como objetivo desenvolver bibliotecas de espectros e calibrações em infravermelho para a quantificação das propriedades do solo.

A Figura 33 apresenta como exemplo, alguns espectros de NIRS obtidos para as amostras TEST, AM, E100 e CC, em 0-10 cm, mostrando os sinais característicos para as mesmas.

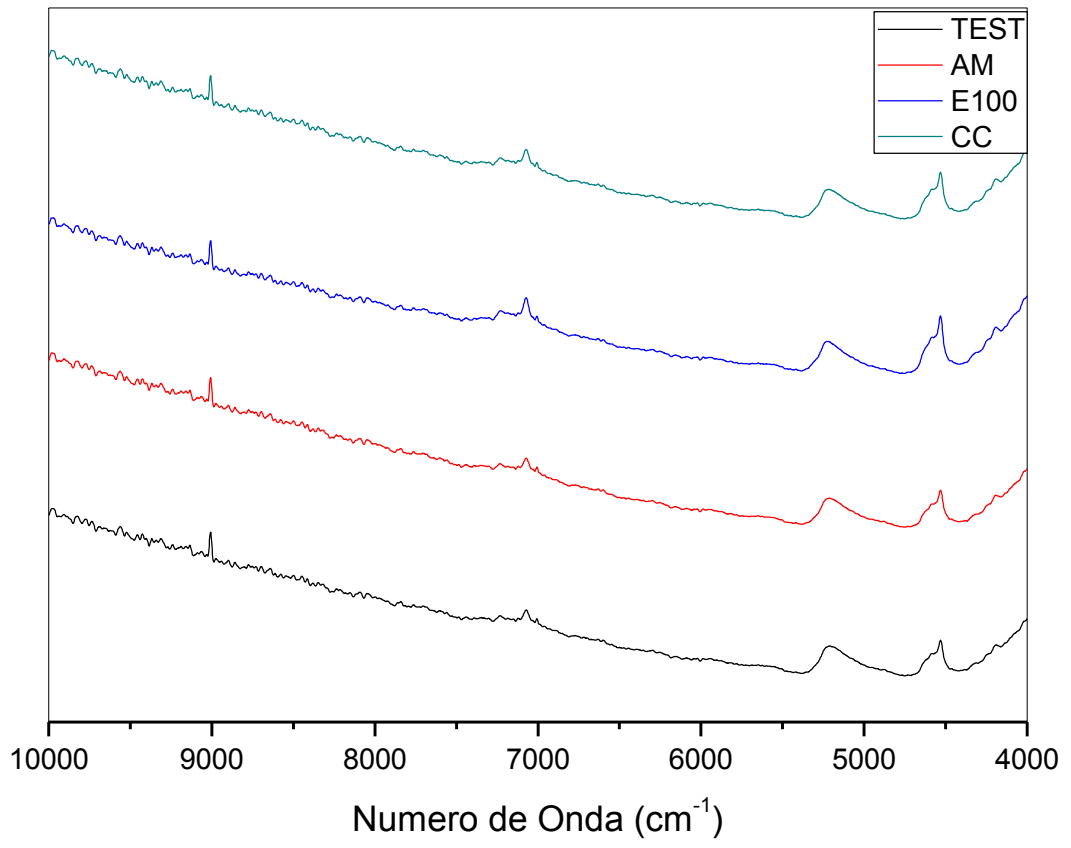

Figura 33: Espectros de NIRS obtidos para algumas amostras em 0-10 cm (TEST, AM, E100 e CC) apresentando as bandas características observadas.

Já na Figura 34 pode-se observar as principais bandas dos espectros obtidos para as amostras, cujas regiões evidenciam maior sensibilidade na obtenção do modelo. 


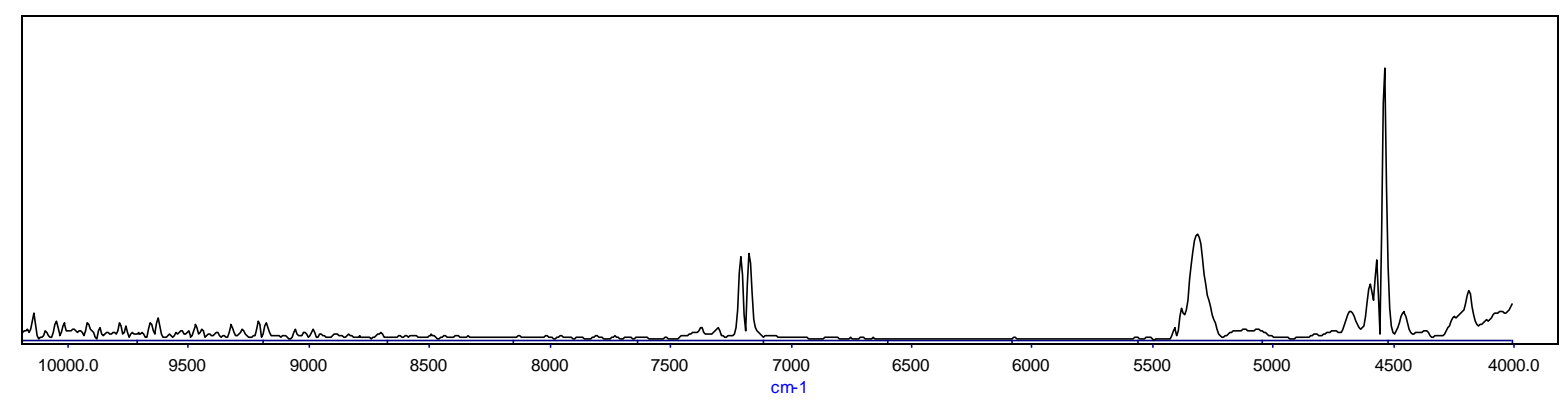

Figura 34: Gráfico obtido evidenciando regiões do espectro (de 10000 a $4000 \mathrm{~cm}^{-1}$ ) de maior sensibilidade e resposta para obtenção do modelo.

Essas três principais regiões com maior resposta correspondem às bandas centradas em $7000 \mathrm{~cm}^{-1}, 5200 \mathrm{~cm}^{-1}$ e $4500 \mathrm{~cm}^{-1}$. Atribui-se ao sinal na região de $7100 \mathrm{~cm}^{-1}$ as vibrações $\mathrm{OH}$ de $\mathrm{Al}(\mathrm{OH})$, evidenciando presença mineral de gibsita, caulinita e/ou montmorilonita. Já na região de aproximadamente $7060 \mathrm{~cm}^{-1}$ e $6960 \mathrm{~cm}^{-1}$, sobrepostas, resultam da $1^{\text {a }}$ harmônica da absorção de $\mathrm{OH}$ de alcoóis e fenóis. Atribui-se também a absorção em $7060 \mathrm{~cm}^{-1}$ às vibrações $\mathrm{OH}$ de moléculas de água adsorvidas pela montmorilonita e à combinação de estiramentos $\mathrm{CH}$.

A sobreposição de bandas nessa região também corresponde às primeiras harmônicas das absorções relativas a vibrações de estiramentos de $\mathrm{O}-\mathrm{H}$ de carboidratos como amido e $\mathrm{N}-\mathrm{H}$ de uréia. A banda centrada em $5300 \mathrm{~cm}^{-1}$ é bem definida, intensa e apresenta-se como característica de amostras de solo. Ela é resultante da $1^{\mathrm{a}}$ harmônica do estiramento $\mathrm{CH}$ de grupos metilas, metilenos e etilenos, da absorção por fosfatos orgânicos e de vários outros grupos funcionais como celulose, lignina, amido, pectina e substâncias húmicas, além de água adsorvida por argilominerais como caulinita e montmorilonita.

A região final dos espectros é marcada por duas bandas com absorção máxima bem definida, situadas em torno de $4500 \mathrm{~cm}^{-1}$, indicam também presença mineral nas amostras que (caulinita e gibsita), além de combinações entre vibrações de estiramentos de $\mathrm{CH}, \mathrm{NH}$ e $\mathrm{OH}$. Também nesta região do espectro são observadas outras duas bandas, menos intensas e pouco definidas, em torno de $4100 \mathrm{~cm}^{-1}$, ocorridas por conta da presença de água adsorvida à gibbsita (FORMAGGIO e EPIPHANIO, 2001; DEMATTÊ et al., 2004, 2005; DALMOLIN et al., 2005; VERGNOUX et al., 2009; FERRARESI, 2010). 


\subsection{4 - ESPECTROSCOPIA DE FLUORESCÊNCIA INDUZIDA POR LASER (FIL)}

As análises de FIL foram feitas a fim de se obter informação a respeito do índice de humificação $\left(\mathrm{H}_{\mathrm{FIL}}\right)$ da matéria orgânica do solo, usando amostras de solo intacto. A proposta de cálculo deste índice de humificação é a razão entre o valor da ACF e o valor de \% de Carbono orgânico total (neste caso, teores obtidos via úmida) presente na amostra de solo intacto (MILORI et al., 2004):

\section{$\mathrm{H}_{\mathrm{FIL}}=\mathrm{ACF} / \mathrm{COT}$}

O índice de humificação obtido através da FIL está representado na Figura 35. Observa-se o aumento do grau de humificação conforme aumenta a profundidade. Na Figura 35 pode-se observar que as amostras que receberam irrigação com o efluente tratado (EE, E50 e E100) demonstraram sensível aumento no índice de humificação da matéria orgânica, na camada de 80-100 cm, exceto pela amostra E100, a qual praticamente igualou-se à amostra AM (tratamento realizado com água e adubação mineral convencional). Essas amostras (EE, E50 e E100) tiveram sutil decréscimo no grau de humificação para a camada 80-100 cm. Isso pode ter acontecido em decorrência de um possível efeito de diluição da matéria orgânica presente, considerando que E100 recebeu volume maior de efluente aplicado. Cabe ressaltar que a diluição da matéria orgânica aportada implica em uma provável lixiviação de nutrientes, atuando negativamente na produção agrícola. Estudos realizados por (MAGALHÃES, et al., 2005) mostraram que a produtividade de vagens na cultura de feijão caupi foi diminuída devido ao intenso volume aplicado de efluente de esgoto tratado e de chuvas.

Nas amostras superficiais $(0-10 \mathrm{~cm})$, de modo geral, observou-se um sutil decréscimo no grau de humificação, ao passo que o teor de carbono mostrava-se mais elevado nestas amostras (corroborando com resultados da Figura 31). FONTAINE et al. (2007) sugerem que a diminuição ocorrida na fração mais recalcitrante da matéria orgânica (grau de humificação) se dá por conta da intensificação da atividade microbiana no solo, estimulada face ao aporte de matéria orgânica fresca em concentrações elevadas.

As amostras CS e CC foram as que apresentaram índices de humificação menores nas profundidades de 80-100 $\mathrm{cm}$. Nesse caso, o efeito da cultura, por se tratar de uma cultura perene (anual), pode ter influenciado a dinâmica de nutrientes e incorporação de matéria orgânica no solo. Além disso, destaca-se o fato de que o sistema radicular do cultivo de citrus 
é diferenciado em relação ao sorgo. Por se tratar da existência de raízes mais profundas, exudatos provenientes das mesmas podem ter influenciado na incorporação/dinâmica da matéria orgânica.

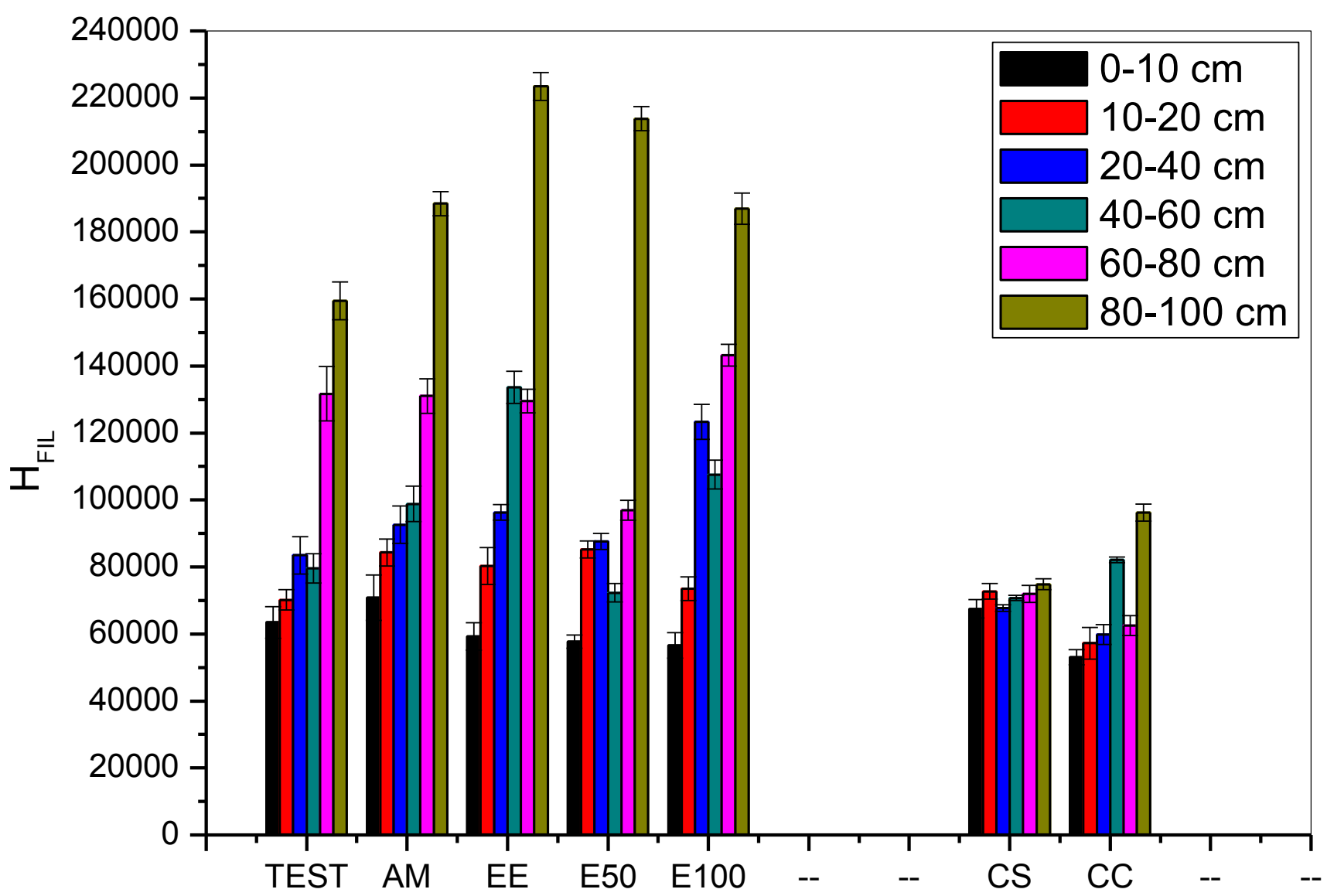

Figura 35: Índices de humificação obtidos para as amostras nos diferentes tratamentos e profundidades, segundo metodologia proposta por (MILORI et al.,2004).

\section{3 - MATÉRIA ORGÂNICA DO SOLO: ÁCIDOS HÚMICOS EXTRAÍDOS}

\subsection{1 - ESPECTROSCOPIA NA REGIÃO DO INFRAVERMELHO MÉDIO COM TRANSFORMADA DE FOURIER}

A Figura 36 apresenta espectros típicos de amostras de ácidos húmicos de solo, representando os principais grupamentos químicos observados nas amostras de solo estudadas. 


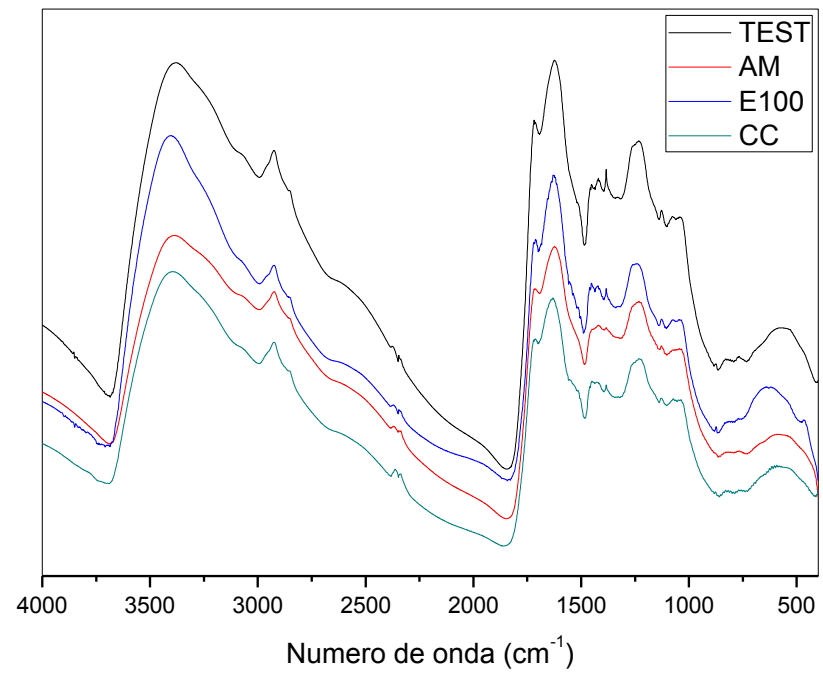

Figura 36: Espectros obtidos por infravermelho médio com Transformada de Fourier para algumas amostras de ácido húmico extraídas dos solos estudados, nos tratamentos TEST, AM, E100 e CC, na profundidade de 0-10 $\mathrm{cm}$.

A faixa entre 3600 e $3070 \mathrm{~cm}^{-1}$ é caracterizada por uma banda larga na região de alta freqüência presente em todos os espectros e é atribuída às vibrações de estiramentos $\mathrm{O}-\mathrm{H}$, indicando a abundância de grupos hidroxilas nos AH obtidos. Na região de 2918 e $2850 \mathrm{~cm}^{-1}$ observa-se a presença de estiramentos assimétrico e simétrico, respectivamente, correspondentes a CH alifáticos (CELI et al., 1997).

Atribui-se à banda em torno de $1718 \mathrm{~cm}^{-1}$ as vibrações $v(\mathrm{O}-\mathrm{C}=\mathrm{O})$ de ésteres ou $v$ $(\mathrm{C}=\mathrm{O})$ de cetonas e ácidos carboxílicos (NAIDJA et al., 2002), enquanto que em torno de $1620 \mathrm{~cm}^{-1}$ tem-se $v(\mathrm{C}=\mathrm{O})$ de grupo amida - banda de amida $\mathrm{I}, \mathrm{C}=\mathrm{C}$ de anel aromático, deformação axial de $\mathrm{C}=\mathrm{C}, \mathrm{C}=\mathrm{N}$, absorção anti-simétrica de $\mathrm{COO}^{-}$e deformação angular de $\mathrm{H}_{2} \mathrm{O}$ (GUIMARÃES, 1997; FAUSTINO, 2007).

A banda caracterizada como fraca em torno de $1420 \mathrm{~cm}^{-1}$ refere-se à presença do estiramento assimétrico $\mathrm{C}-\mathrm{O}$ e /ou a deformação $\mathrm{C}-\mathrm{O}-\mathrm{H}$ dos $\mathrm{COOH}$ e estiramento simétrico dos íons $\mathrm{COO}^{-}$. A banda próxima a $1236 \mathrm{~cm}^{-1}$ é atribuída à deformação axial C-O dos $\mathrm{COOH}$ e estiramento simétrico C-O. Ainda, as absorções observadas entre $1200-1100 \mathrm{~cm}^{-1}$ podem ser atribuídas ao $v(\mathrm{C}-\mathrm{O})$ de polissacarídeos possivelmente celulose ou hemicelulose residual ou ainda, impurezas de silicatos relacionadas ao $v$ (Si-O) (STEVENSON, 1994).

Como o número de amostras é consideravelmente grande, não foi interessante exibir os espectros de cada uma delas, já que visualmente, os espectros são bastante semelhantes uns aos outros, não sendo observadas alterações significativas nas bandas de absorção face a adição da matéria orgânica do efluente. Em virtude do grande volume de dados obtidos nos espectros para todas as amostras(números de onda e absorbância) e na tentativa de estabelecer possíveis relações entre os tratamentos que as amostras receberm, bem como as 
profundidades, optou-se por utilizar a análise multivariada de dados, por meio da Análise de Componentes Principais (PCA). Para tal, utilizou-se o software Pirouette ${ }^{\circledR}$ da Infometrix, versão 3.11, adquirido pela Embrapa Instrumentação Agropecuária. As análises de PCA foram conduzidas partindo-se do cálculo da primeira derivada com 5 pontos para os espectros, com dados centrados na média.

A análise de PCA resultante descreve $90 \%$ dos dados com 5 componentes principais. A separação das amostras por similaridade e tendências de grupamentos pode ser observada na Figura 37.

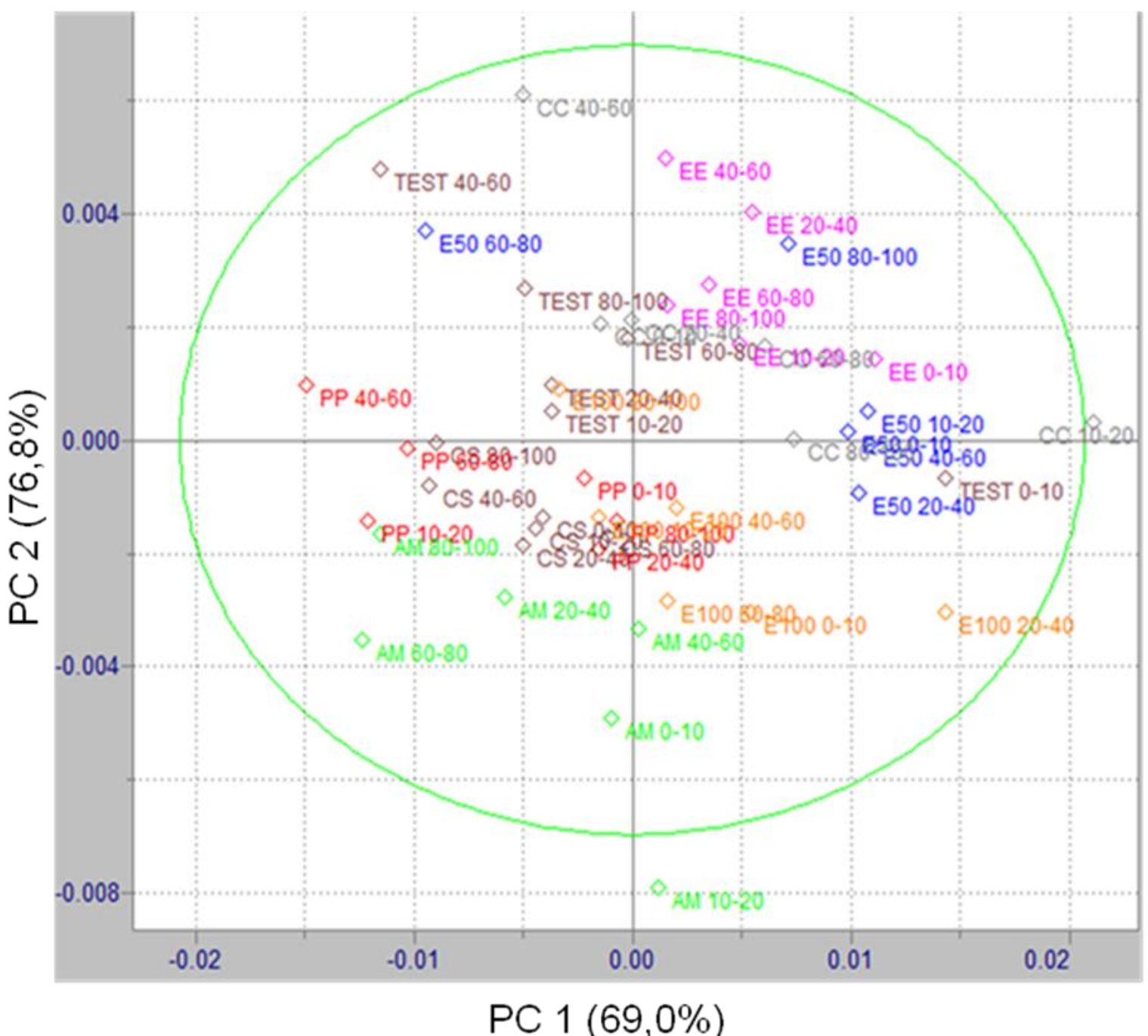

Figura 37: Gráfico da PC1 vs. PC2, representando a separação das amostras por semelhança e tendência de grupamentos.

Com a realização da PCA, não foi possível separar claramente grupamentos de amostras cujas características de grupos funcionais sejam semelhantes. Contudo, pode-se notar, localizada nos quadrantes do lado direito, separados pela PC1, uma maior concentração das amostras que receberam tratamentos com efluente, sugerindo uma tendência de separação 
dessas amostras em relação as demais, face alguma alteração provocada pela adição de efluente na matéria orgânica presente nessas amostras.

\subsection{2 - ESPECTROSCOPIA DE FLUORESCÊNCIA EM SOLUÇÃO: MODALIDADES DE EMISSÃO E SINCRONIZADA}

As vantagens desta técnica consistem na alta sensibilidade e seletividade, uma vez que somente aqueles grupos funcionais que fluorescem podem ser observados. Com isso, o uso da técnica de fluorescência nos estudos sobre substâncias húmicas está apoiado pela presença estável de várias estruturas fluorescentes intrínsecas a molécula húmica e a seus precursores, particularmente anéis aromáticos, fenóis e grupos quinona (SENESI et al., 1991).

a) Modalidade de Emissão

Os espectros de emissão foram obtidos utilizando a metodologia proposta por MILORI et al., (2002), a qual propõe a excitação das amostras em $465 \mathrm{~nm}$.

$\mathrm{Na}$ Figura 38 pode-se observar exemplos de espectros obtidos por meio dessa modalidade de fluorescência:

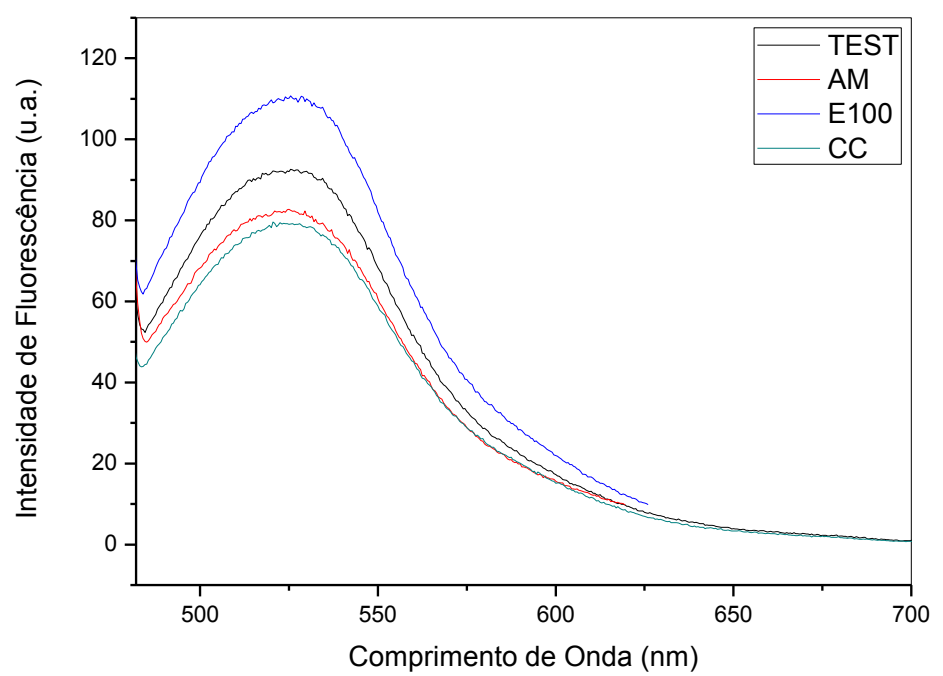

Figura 38: Espectros obtidos por meio da modalidade de emissão, segundo metodologia de (MILORI et al., 2002), de algumas amostras de ácido húmico extraídas dos solos estudados, para os tratamentos TEST, AM, E100 e CC na profundidade de $0-10 \mathrm{~cm}$.

Segundo MILORI et al. (2002), uma boa estimativa do índice de humificação para amostras de $\mathrm{AH}$ pode ser obtida integrando-se a área sob a curva dos espectros de emissão com $\lambda_{\text {ex }}=465 \mathrm{~nm}$, sendo denominado A465. A Figura 39 mostra os índices de humificação calculados para as amostras de AH extraídos. 


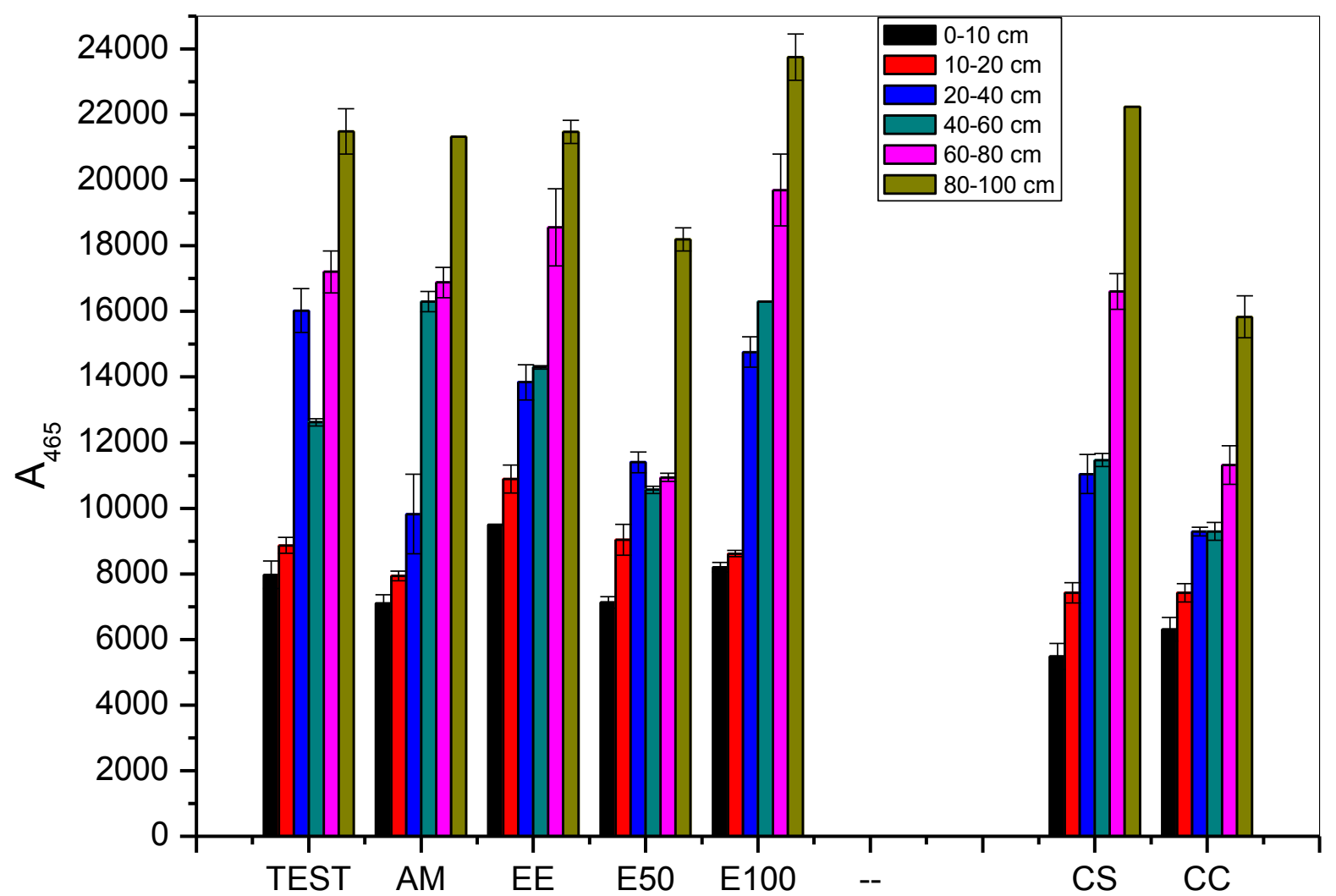

Figura 39: Gráficos dos índices de humificação $\left(\mathrm{A}_{465}\right)$ obtidos para as amostras dos diferentes tratamentos nas seis profundidades estudadas.

Ao longo das profundidades, observa-se, de modo geral, uma tendência de aumento do índice de humificação nos tratamentos estudados. A amostra da camada de 80-100 cm de E100 tem destaque em relação às demais, por apresentar um superior índice de humificação. Não foram observadas tendências em relação a este índice para as amostras que receberam efluente de modo geral. Superficialmente $(0-10 \mathrm{~cm})$, a amostra EE apresentou índice de humificação sutilmente superior. As amostras que receberam dosagens de efluente comportaram-se igualmente ou de maneira superior às amostras que receberam adubação mineral convencional, principalmente nas camadas superficiais.

Para as amostras sob cultivo de citrus, nota-se que embora CC apresente índice de humificação ligeiramente superior que CS, essa amostra apresenta diminuição no referido índice quando este é observado na camada de $80-100 \mathrm{~cm}$. Isto pode ter ocorrido devido a um possível consumo da fração mais estável (recalcitrante) do carbono, ocasionada pela intensificação da atividade microbiana após aporte de matéria orgânica fresca, como sugere FONTAINE et al. (2007). 
b) Modalidade Sincronizada:

O espectro de varredura sincronizada, medida com diferença constante entre excitação e emissão $(\Delta \lambda=55 \mathrm{~nm})$, permitiu avaliar o grau de humificação através da metodologia proposta por KALBITZ et al., (2000). De acordo com essa proposta, os espectros de fluorescência sincronizados das substâncias húmicas apresentam dois máximos de emissão, um em torno de 360 e outro em $465 \mathrm{~nm}$, e um ombro em torno de $470 \mathrm{~nm}$. Estas bandas podem apresentar deslocamento de intensidade de fluorescência de menores para maiores comprimentos de onda, o que está associado com um aumento no número de núcleos aromáticos altamente substituídos e/ ou com um sistema conjugado insaturado capaz de exibir alto grau de ressonância. Então, a razão da intensidade de fluorescência em 400 e 360 nm, ou 470 e $360 \mathrm{~nm}$ pode ser usada para medir o grau de humificação das substâncias húmicas.

Na Figura 40, estão alguns exemplos de espectros empregando essa metodologia, e onde podem ser identificadas uma banda bem definida em torno de 470, e outra bem sutil em $377 \mathrm{~nm}$, as quais foram usados na determinação do índice de humificação, medindo-se a razão $\mathrm{I}_{470} / \mathrm{I}_{377}$.

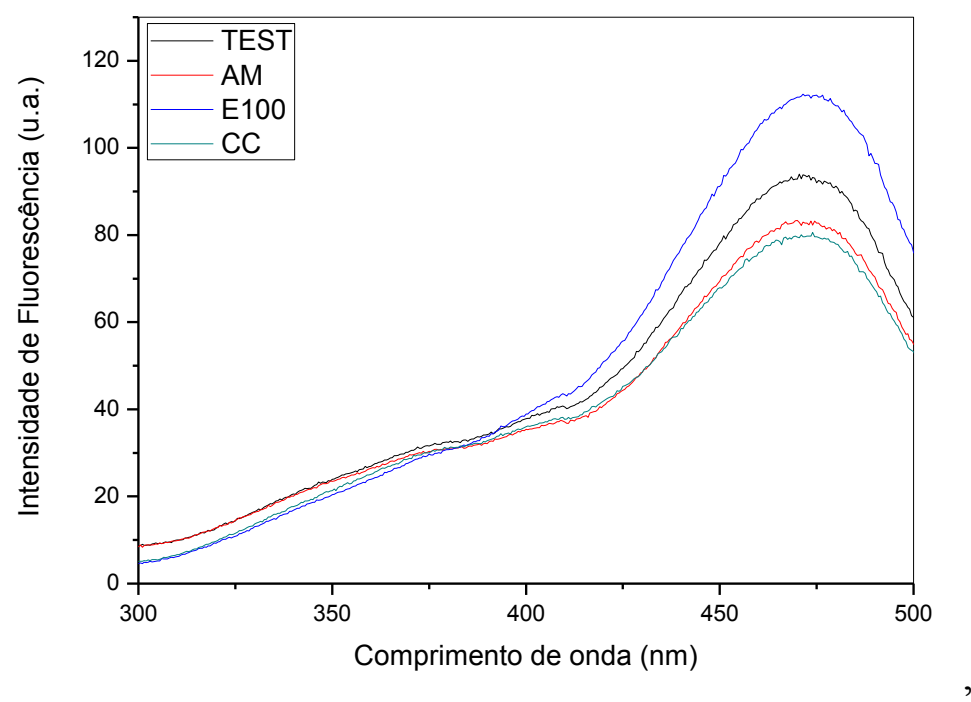

Figura 40: Espectros obtidos por meio da modalidade sincronizada, segundo metodologia de (KALBITZ et al., 2000), de algumas amostras de ácido húmico extraídas dos solos estudados, para os tratamentos TEST, AM, E100 e CC na profundidade de $0-10 \mathrm{~cm}$.

A Figura 41 apresenta os gráficos dos índices de humificação obtidos para os ácidos húmicos extraídos. 


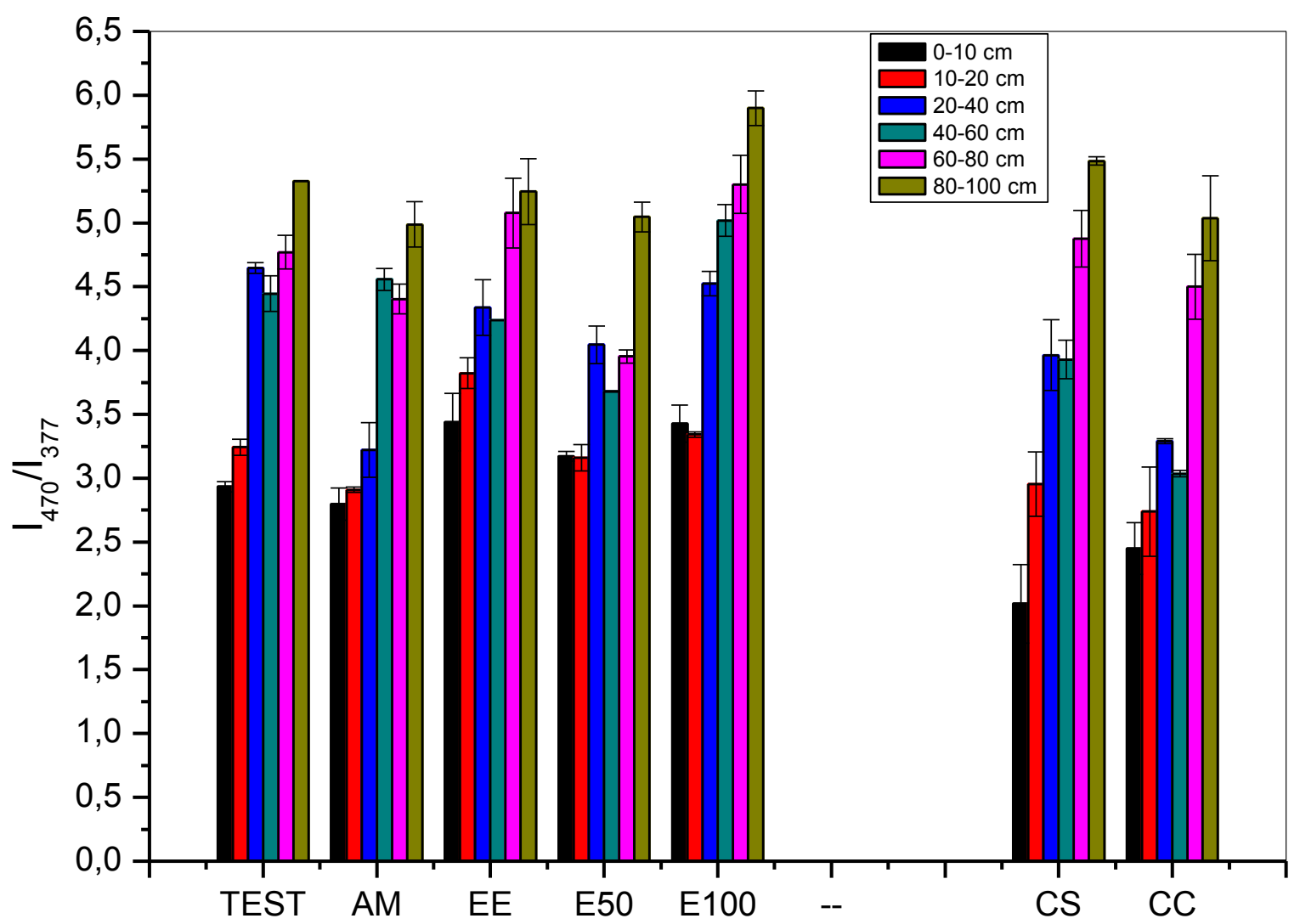

Figura 41: Gráficos dos índices de humificação $\left(\mathrm{I}_{470} / \mathrm{I}_{377}\right)$ obtidos para as amostras dos diferentes tratamentos nas seis profundidades estudadas.

Os índices encontrados para a metodologia proposta por (KALBITZ et al., 2000) corroboram com os índices de humificação obtidos segundo (MILORI et al., 2002). Na profundidade de 80-100 cm, como esperado, os índices para o grau de humificação são superiores quando comparados às camadas mais superficiais do solo, visto que é justamente nesta profundidade que se encontra a porção mais recalcitrante e aromática da matéria orgânica.

Os gráficos sugerem uma sutil elevação para o índice de humificação para a amostra E100, bem como o índice de humificação de comportamento similar ou superior das amostras que receberam irrigação com efluente em relação à adubação mineral convencional.

É relevante ressaltar, contudo, que o tempo curto de aplicação do efluente para as amostras do experimento com o sorgo pode não ter incorporado a matéria orgânica de modo mais efetivo. Além disso, não descarta-se efeito de lixiviação, decorrente das chuvas e também do elevado volume de efluente aplicado. Além disso, vale ressaltar também que as determinações utilizando fluorescência em solução avaliam a parte húmica do solo, o que corresponde apenas a uma fração desse. 
Embora CC tenha recebido irrigação com o efluente por mais tempo que as outras amostras, a mesma também não apresentou alteração significativa em relação às demais amostras investigadas. Seu índice de humificação, em relação à CS foi sutilmente superior para a camada superficial e inferior para a camada de $80-100 \mathrm{~cm}$, sugerindo o mesmo comportamento observado nos resultados obtidos pela metodologia proposta por MILORI et al. (2002).

\subsection{3 - MEDIDA DE TAMANHO DE PARTÍCULAS E POTENCIAL ZETA}

Para as medidas de Potencial Zeta, os resultados do planejamento experimental cujos experimentos foram descritos no capítulo 4, encontram-se na Figura 42, com o gráfico de efeitos $v s$ z scores calculados.

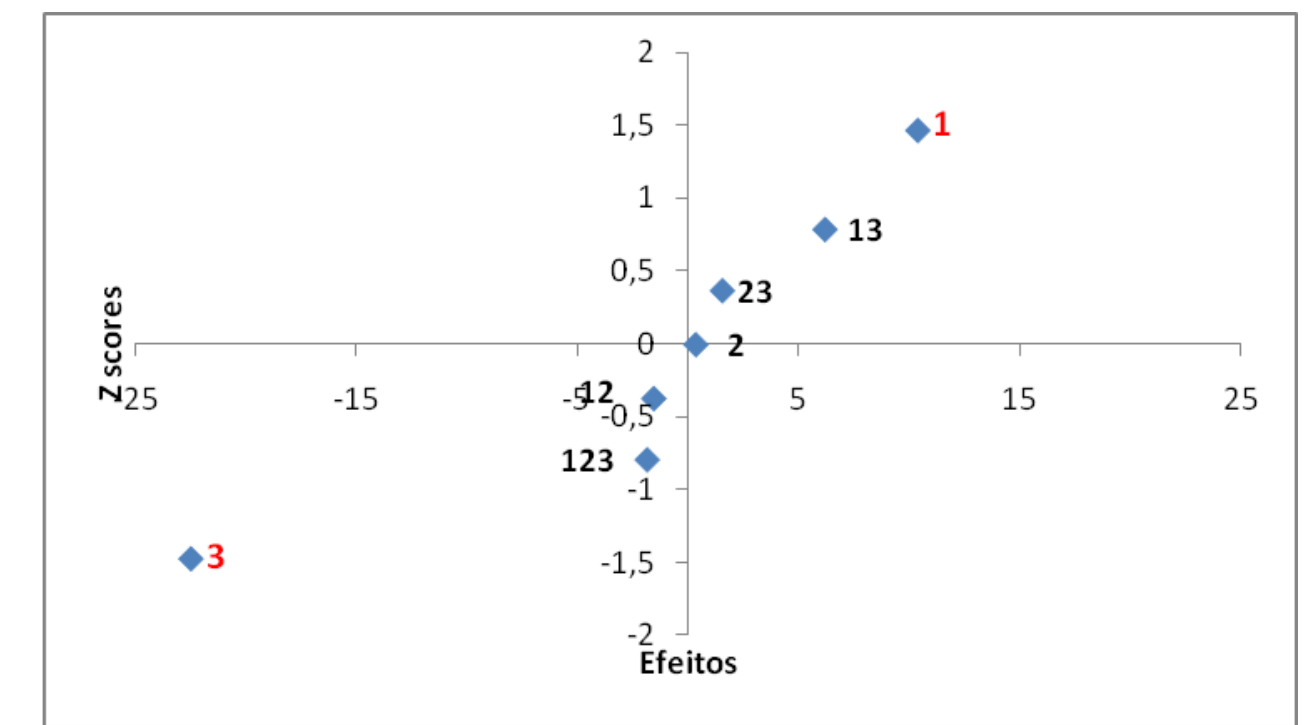

Figura 42: Gráfico de Efeitos vs. Z scores calculados, obtidos através dos resultados da análises realizadas estabelecidas pelo planejamento fatorial

Nota-se de acordo com a Figura 42 que as variáveis mais distantes dos eixos (em vermelho) correspondem às variáveis que exerceram maior significância durante a realização dos experimentos propostos pelo planejamento fatorial. São elas as variáveis 1 e 3, concentração iônica e pH do meio, respectivamente.

Na Figura 43 encontra-se um gráfico que ilustra o perfil das respostas conforme as variáveis são mudadas do menor para o maior nível nas condições estudadas. 


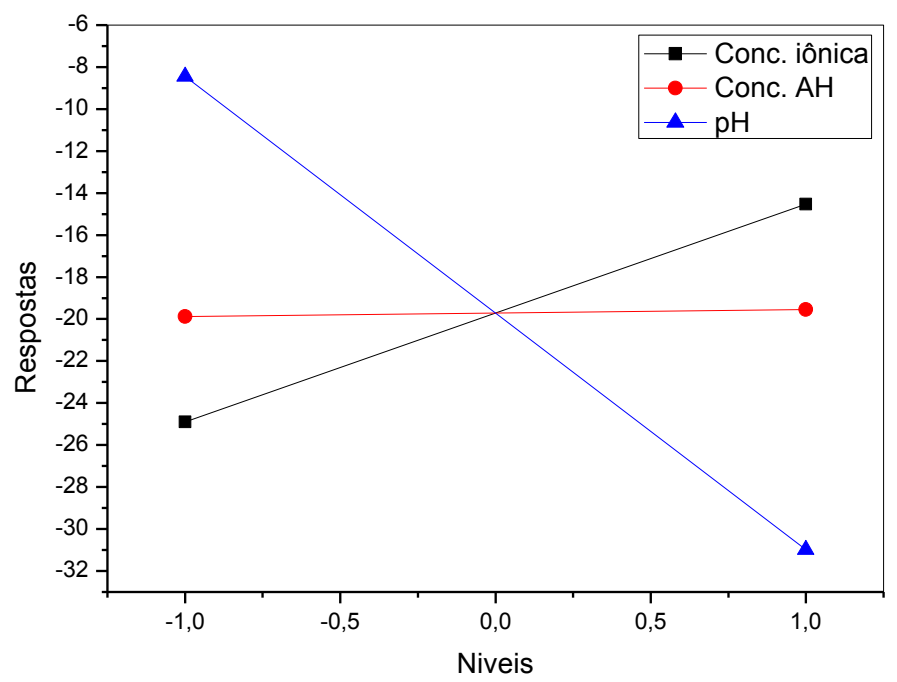

Figura 43: Respostas obtidas para potencial Zeta alternando-se as variáveis do nível inferior para o superior

Para as condições estudadas, a concentração de ácido húmico variando de 100 ppm para $200 \mathrm{mg} \mathrm{L}^{-1}$ não influenciou nas medidas de potencial Zeta. Variando-se o pH de 2 a 12, os valores medidos para o potencial Zeta foram mais negativos. Com o aumento de $\mathrm{pH}$, as partículas tendem a expandir e repelem-se eletrostaticamente. As forças existentes se tornam mais fracas, devido à ligações de hidrogênio, interações de van der Waals e interações de elétrons $\pi$ de moléculas adjacentes, com dissociação de grupos fenólicos e carboxílicos gerando cargas negativas (SAAB et al., 2010).

Com o aumento da concentração iônica do meio de $0,05 \mathrm{~mol} \mathrm{~L}^{-1}$ a $0,5 \mathrm{~mol} \mathrm{~L}^{-1}$, os valores de potencial Zeta tendem a tornar-se mais positivos, já que os íons em solução acabam por neutralizar as cargas formadas na expansão das partículas, e de acordo com (WARWICK et al., 2001) havendo compressão da dupla camada coloidal. Os resultados estão de acordo com os observados por SIMÕES (2005), empregando Espectroscopia de Ressonância Paramagnética Eletrônica e marcadores de spin.

Para as medidas envolvendo tamanho de partículas, os resultados do planejamento experimental cujos experimentos foram descritos no capítulo 4 e calculados por meio da média ponderada dos valores. Tais resultados encontram-se na Figura 44, com o gráfico de efeitos vs z scores calculados. 


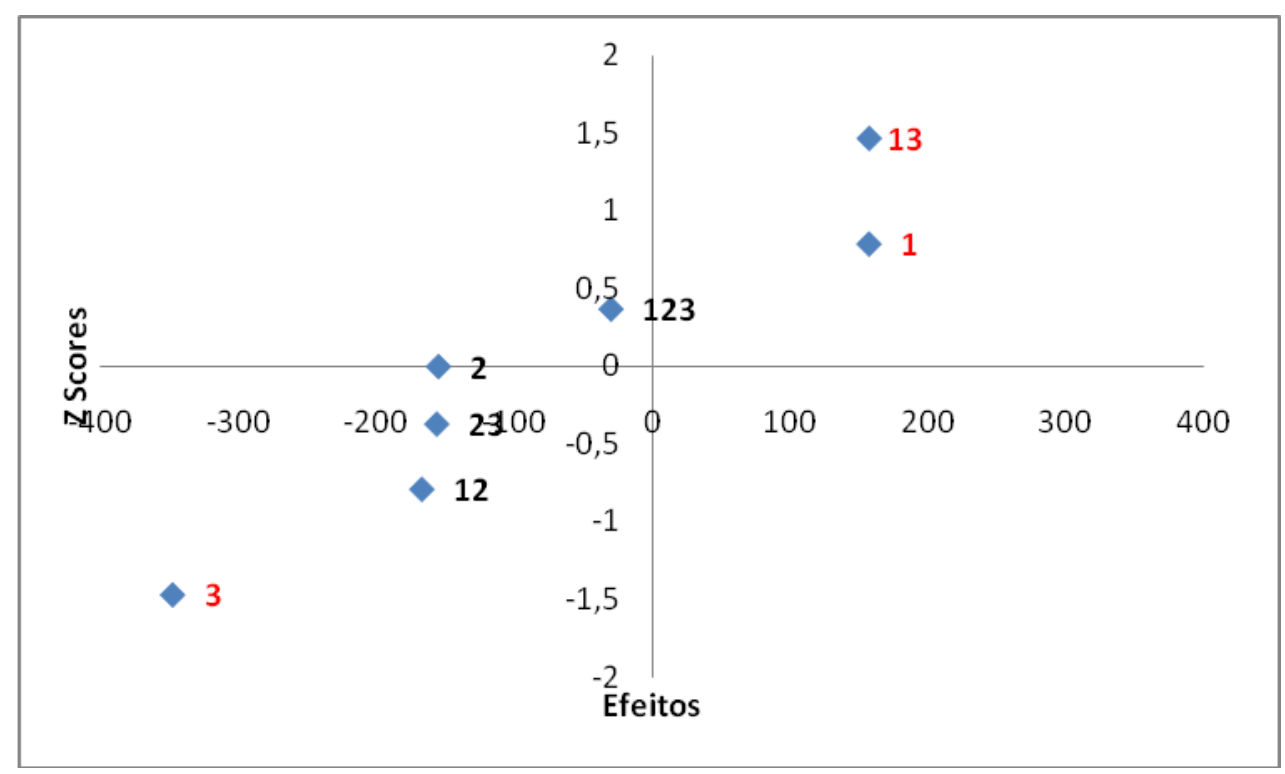

Figura 44: Respostas obtidas para tamanho de partículas alternando-se as variáveis do nível inferior para o superior

De acordo com a Figura 44, observa-se que as variáveis mais distantes dos eixos (em vermelho) correspondem às variáveis que exerceram maior significância durante a realização dos experimentos propostos pelo planejamento fatorial. São elas as variáveis 1 e 3 , bem com a interação proveniente dessas duas variáveis, concentração iônica e pH do meio, respectivamente.

Na Figura 45 encontra-se um gráfico que ilustra o perfil das respostas conforme as variáveis são mudadas do menor para o maior nível nas condições estudadas.

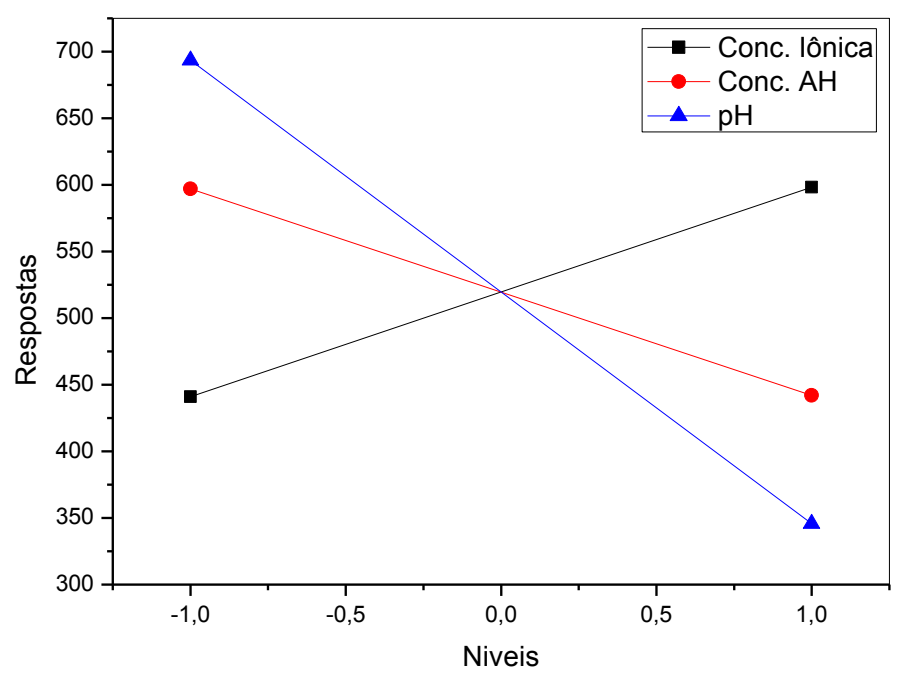

Figura 45: Respostas obtidas para medidas de tamanho de partículas alternando-se as variáveis do nível inferior para o superior 
Nas condições estudadas, a concentração de ácido húmico variou ligeiramente, bem como a mudança na concentração iônica do meio. Aumentando-se a concentração de ácido húmico, o tamanho das partículas diminuiu ligeiramente. Um aumento sutil no tamanho das partículas ocorreu devido ao aumento da concentração iônica do meio. Estas características dão suporte ao comportamento que corresponde à teoria supramolecular das substâncias húmicas (PICCOLO et al., 2001).

Diversos estudos evidenciam, contudo, que em sistemas macromoleculares o aumento da concentração iônica do meio diminui forças de repulsão intra e intermoleculares, favorecendo a contração da molécula e a expulsão de moléculas de solvente presentes na molécula (PÉDROT et al., 2010).

REN et al. (1996) mostraram que o raio hidrodinâmico a partir de medidas de espalhamento de luz dinâmico diminuíram da ordem de 50\% (de 95 a 48 nm) quando a concentração iônica do meio foi aumentada em 100 vezes em pH igual a 9.

Estudos que afirmam que as substâncias húmicas comportam-se como associações moleculares demonstraram que o aumento da concentração iônica do meio poderia diminuir a hidratação das substâncias húmicas, o que implica na redução do volume molar dos ácidos húmicos e por isso, o tamanho (PICCOLO et al., 2001).

Estudos conduzidos por (ALVAREZ-PUEBLA et al., 2005) descrevem que conforme os grupos ácidos dos $\mathrm{AH}$ vão sendo ionizados a medida que a concentração hidrogeniônica do meio diminui, aumenta-se a repulsão eletrostática intra e intermolecular, restringindo o fenômeno de agregação. Por outro lado, a ionização de grupamentos ácidos elimina prótons que tem a tendência de formar ligações de hidrogênio, através disso também impedindo agregação entre diferentes colóides.

Em processos de simulação de agregação de partículas, (ALVAREZ-PUEBLA et al., 2005) também menciona que o tamanho molecular aumenta com aumento no valor de $\mathrm{pH}$ devido à repulsão eletrostática intramolecular, enquanto que o tamanho dos agregados decresce com o aumento do $\mathrm{pH}$, por conta do aumento das repulsões moleculares.

Estabelecendo-se as variáveis de maior impacto para os experimentos conduzidos, escolheram-se as variáveis de maior interesse para investigar o comportamento das amostras TEST, AM e E100 nas seis profundidades. O intuito foi analisar tratamentos bem distintos de amostras. Utilizou-se o pH variando de 2 a 12, com medidas também executadas em pH igual a 7; concentração de ácido húmico correspondendo a 100 ppm e concentração iônica do meio em $0,05 \mathrm{~mol} \mathrm{~L}^{-1}$. 
As Tabelas 14, 15 e 16 apresentam, em resumo, para os três tratamentos avaliados, a intensidade de partículas nas faixas de tamanho correspondentes, bem como seus tamanhos médios nos diferentes valores de $\mathrm{pH}$ investigados e nas diferentes profundidades.

Tabela 14: Intensidade de partículas, faixas de tamanho e tamanhos médios para as amostras TEST, nas diferentes profundidades:

\begin{tabular}{|c|c|c|c|c|}
\hline $\begin{array}{l}\text { Profundidade } \\
\quad(\mathrm{cm})\end{array}$ & $\begin{array}{c}\text { Valor de } \\
\mathrm{pH}\end{array}$ & $\begin{array}{l}\text { Intensidade de } \\
\text { partículas } \\
(\%)\end{array}$ & $\begin{array}{c}\text { Faixa de } \\
\text { tamanho } \\
(\mathrm{nm})\end{array}$ & $\begin{array}{c}\text { Tamanho } \\
\text { Médio } \\
(\mathrm{nm})\end{array}$ \\
\hline \multirow{4}{*}{$0-10$} & 2 & 100 & $190-1280$ & 641 \\
\hline & 7 & $\begin{array}{c}96 \\
4\end{array}$ & $\begin{array}{c}16-955 \\
4800-5560\end{array}$ & $\begin{array}{c}239 \\
5149\end{array}$ \\
\hline & & 19 & $24-43$ & 34 \\
\hline & 12 & 81 & $91-531$ & 215 \\
\hline \multirow{5}{*}{$10-20$} & 2 & 100 & $458-955$ & 689 \\
\hline & & 88,7 & 11,7-955 & 202 \\
\hline & 7 & 11,2 & $2669-5560$ & 4677 \\
\hline & & 92,4 & $21-955$ & 163 \\
\hline & 12 & 7,6 & $2669-5560$ & 4581 \\
\hline \multirow{5}{*}{$20-40$} & 2 & 100 & $295-712$ & 486 \\
\hline & & 92,1 & $32-1718$ & 284 \\
\hline & 7 & 8,2 & $1990-5560$ & 4313 \\
\hline & & 91,4 & $11-1718$ & 265 \\
\hline & 12 & 8,6 & $2305-5560$ & 4470 \\
\hline \multirow{5}{*}{$40-60$} & 2 & 100 & $91-825$ & 412 \\
\hline & & 93,9 & $9-1281$ & 265 \\
\hline & 7 & 6 & $3580-5560$ & 5008 \\
\hline & & 92,1 & $37-1281$ & 352 \\
\hline & 12 & 7,9 & $3091-5560$ & 4822 \\
\hline \multirow{4}{*}{$60-80$} & 2 & 100 & $122-955$ & 521 \\
\hline & & 98,8 & $10-615$ & 159 \\
\hline & 7 & 1,6 & 5560 & 5560 \\
\hline & 12 & 100 & $21-1106$ & 312 \\
\hline \multirow{5}{*}{$80-100$} & 2 & 100 & $91-712$ & 404 \\
\hline & & 97,2 & $24-615$ & 140 \\
\hline & 7 & 2,8 & $2669-5560$ & 4504 \\
\hline & & 87 & $24-295$ & 90 \\
\hline & 12 & 12,9 & $531-5560$ & 2597 \\
\hline
\end{tabular}


Tabela 15: Intensidade de partículas, faixas de tamanho e tamanhos médios para as amostras AM, nas diferentes profundidades:

\begin{tabular}{|c|c|c|c|c|}
\hline $\begin{array}{l}\text { Profundidade } \\
\text { (cm) }\end{array}$ & $\begin{array}{c}\text { Valor de } \\
\mathrm{pH}\end{array}$ & $\begin{array}{l}\text { Intensidade de } \\
\text { partículas } \\
(\%)\end{array}$ & $\begin{array}{c}\text { Faixa de } \\
\text { tamanho } \\
(\mathrm{nm})\end{array}$ & $\begin{array}{l}\text { Tamanho } \\
\text { Médio } \\
(\mathrm{nm})\end{array}$ \\
\hline \multirow{4}{*}{$0-10$} & 2 & 100 & $141-955$ & 467 \\
\hline & 7 & $\begin{array}{c}94,6 \\
4.5\end{array}$ & $\begin{array}{c}50-825 \\
4801-5560\end{array}$ & $\begin{array}{c}382 \\
5408\end{array}$ \\
\hline & & 97,5 & $58-825$ & 320 \\
\hline & 12 & 2,5 & 5560 & 5560 \\
\hline \multirow{4}{*}{$10-20$} & 2 & 100 & $396-955$ & 619 \\
\hline & & 92,1 & $10-1484$ & 194 \\
\hline & 7 & 7,7 & $2305-5560$ & 4434 \\
\hline & 12 & 100 & $15-5560$ & 806 \\
\hline \multirow{5}{*}{$20-40$} & 2 & 100 & $122-955$ & 507 \\
\hline & & 92,1 & $37-712$ & 179 \\
\hline & 7 & 7,7 & $1718-5560$ & 3965 \\
\hline & & 92,4 & $8,7-1281$ & 148 \\
\hline & 12 & 7,7 & $3091-5560$ & 4813 \\
\hline \multirow{5}{*}{$40-60$} & 2 & 100 & $91-825$ & 535 \\
\hline & & 97,4 & $21-531$ & 174 \\
\hline & 7 & 2,6 & $4801-5560$ & 5501 \\
\hline & & 25,2 & $32-58$ & 47 \\
\hline & 12 & 74,8 & $164-295$ & 239 \\
\hline \multirow{5}{*}{$60-80$} & 2 & 100 & $141-955$ & 593 \\
\hline & & 93,9 & $24-955$ & 217 \\
\hline & 7 & 6 & $3580-5560$ & 5097 \\
\hline & & 93,9 & $24-955$ & 217 \\
\hline & 12 & 6 & $3580-5560$ & 5097 \\
\hline \multirow{4}{*}{$80-100$} & 2 & 100 & $105-825$ & 437 \\
\hline & & 95,5 & $32-712$ & 210 \\
\hline & 7 & 4,4 & $3091-5560$ & 4709 \\
\hline & 12 & 100 & $11-5560$ & 522 \\
\hline
\end{tabular}


Tabela 16: Intensidade de partículas, faixas de tamanho e tamanhos médios para as amostras E100, nas diferentes profundidades

\begin{tabular}{|c|c|c|c|c|}
\hline $\begin{array}{l}\text { Profundidade } \\
(\mathrm{cm})\end{array}$ & $\begin{array}{c}\text { Valor de } \\
\text { pH }\end{array}$ & $\begin{array}{l}\text { Intensidade de } \\
\text { partículas } \\
(\%)\end{array}$ & $\begin{array}{c}\text { Faixa de } \\
\text { tamanho } \\
(\mathrm{nm})\end{array}$ & $\begin{array}{c}\text { Tamanho } \\
\text { Médio } \\
\text { (nm) }\end{array}$ \\
\hline \multirow{3}{*}{$0-10$} & 2 & 100 & $122-825$ & 456 \\
\hline & 7 & $\begin{array}{c}96,3 \\
3,6\end{array}$ & $\begin{array}{l}24-825 \\
4801-5560\end{array}$ & $\begin{array}{c}276 \\
5433\end{array}$ \\
\hline & 12 & 100 & $58-712$ & 274 \\
\hline \multirow{4}{*}{$10-20$} & 2 & 100 & $122-825$ & 502 \\
\hline & 7 & 100 & $37-615$ & 230 \\
\hline & & 96,3 & $21-955$ & 342 \\
\hline & 12 & 3,6 & $4801-5560$ & 5412 \\
\hline \multirow{3}{*}{$20-40$} & 2 & 100 & $105-712$ & 459 \\
\hline & 7 & 100 & $15-5560$ & 1079 \\
\hline & 12 & 100 & $13-5560$ & 629 \\
\hline \multirow{4}{*}{$40-60$} & 2 & 100 & $255-458$ & 336 \\
\hline & & 85,8 & $24-1281$ & 259 \\
\hline & 7 & 14,2 & $1990-5560$ & 4312 \\
\hline & 12 & 100 & $21-5560$ & 1396 \\
\hline \multirow{5}{*}{$60-80$} & 2 & 100 & $78-712$ & 413 \\
\hline & & 97 & $13-1718$ & 422 \\
\hline & 7 & 2,9 & $3580-5560$ & 4943 \\
\hline & & 91,6 & $7-1281$ & 245 \\
\hline & 12 & 8,5 & $3580-5560$ & 5009 \\
\hline \multirow{5}{*}{$80-100$} & 2 & 100 & $342-712$ & 492 \\
\hline & & 93,3 & $58-1484$ & 413 \\
\hline & 7 & 6,8 & $4145-5560$ & 5285 \\
\hline & & 93,5 & $18-1484$ & 296 \\
\hline & 12 & 6,7 & $3580-5560$ & 5072 \\
\hline
\end{tabular}

A Figura 46 mostra os resultados para distribuição de tamanho das amostras TEST, nas seis profundidades e nos valores de $\mathrm{pH}$ iguais a 2,7 e 12 .
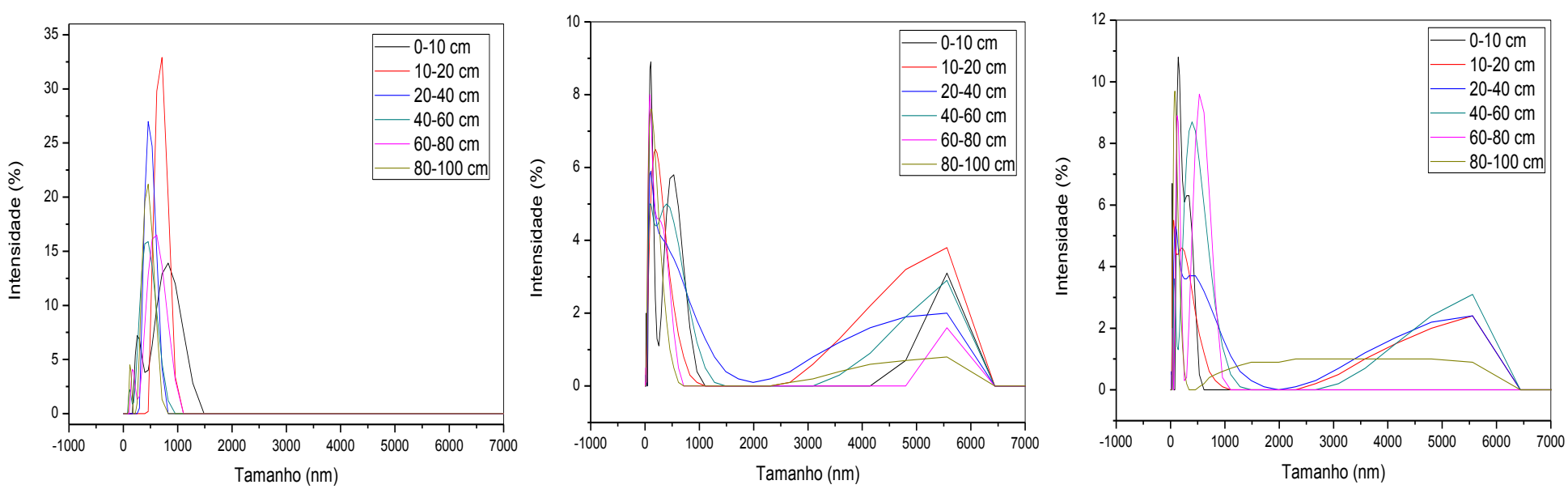

Figura 46: Gráficos das distribuições de tamanho de partículas pela intensidade das amostras TEST, nas seis profundidades estudadas e em $\mathrm{pH}$ igual a 2,7 e 12 , respectivamente. 
As Figuras 47 e 48 apresentam os gráficos de distribuição de tamanho pela intensidade das amostras AM e E100, respectivamente, nas seis profundidades distintas e em valores de $\mathrm{pH}$ iguais a 2,7 e 12 .
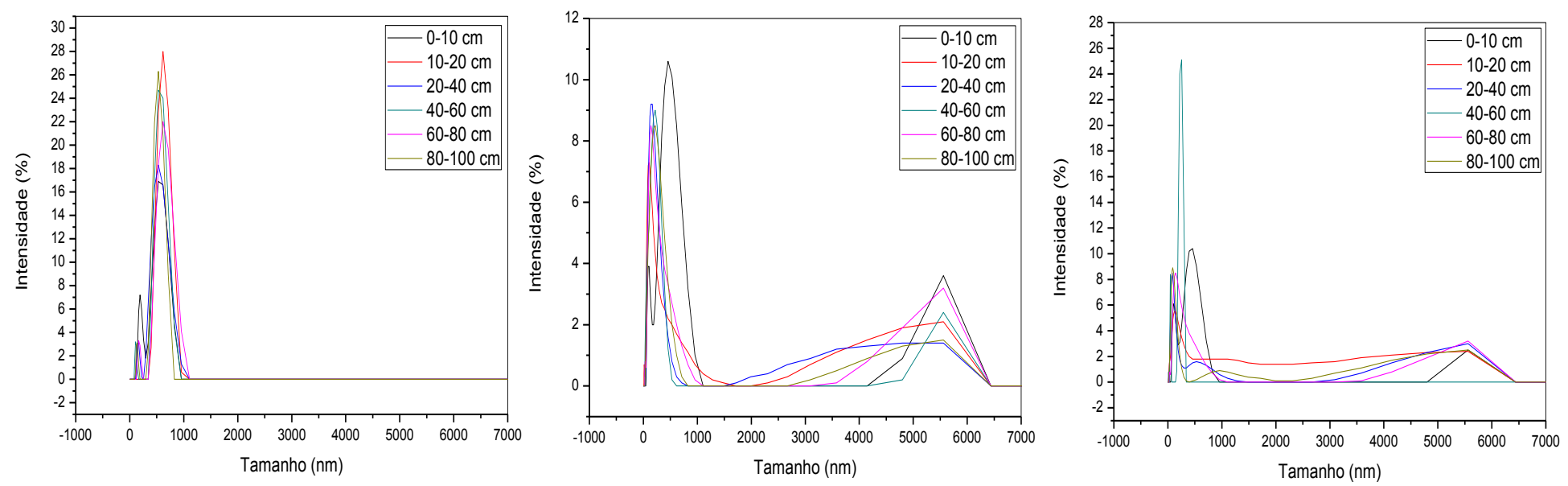

Figura 47: Gráficos das distribuições de tamanho de partículas pela intensidade das amostras AM, nas seis profundidades estudadas e em $\mathrm{pH}$ igual a 2,7 e 12 , respectivamente.
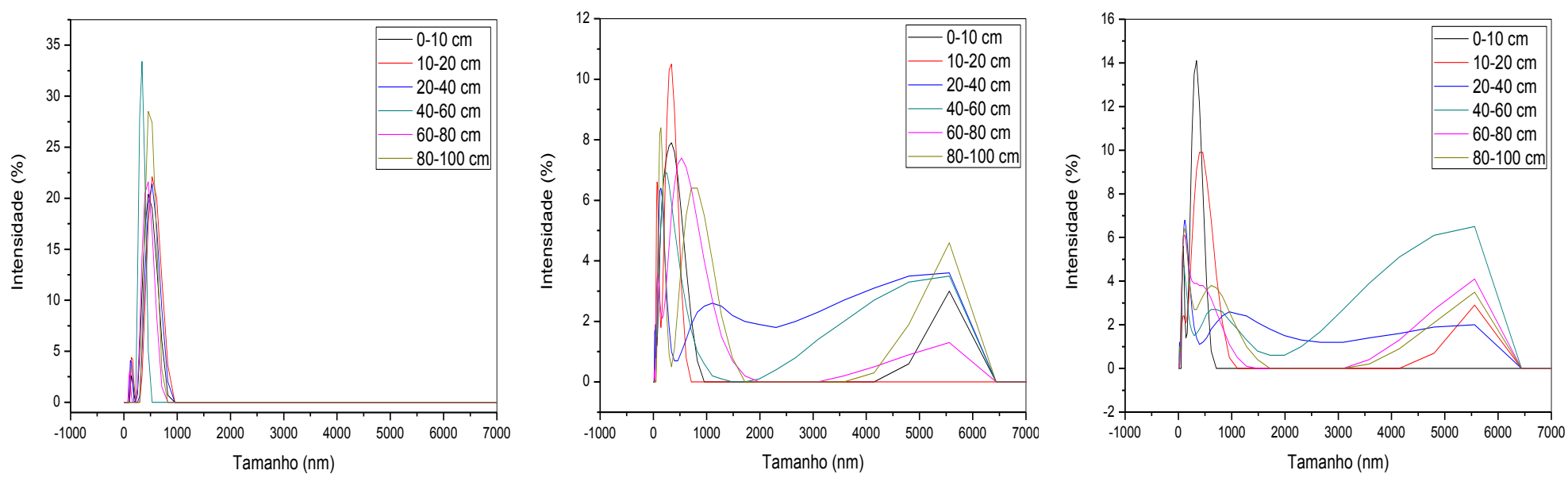

Figura 48: Gráficos das distribuições de tamanho de partículas pela intensidade das amostras E100, nas seis profundidades estudadas e em $\mathrm{pH}$ igual a 2,7 e 12 , respectivamente.

Foram observados tanto para as amostras TEST, quanto para AM e E100, de maneira geral, um comportamento semelhante. As profundidades não apresentaram características relevantes que pudessem associar o comportamento do tamanho de partículas com a recalcitrância da matéria orgânica. Notou-se que em pH igual a 2, as partículas são de modo geral menores, compreendendo uma faixa até $1500 \mathrm{~nm}$. Com o aumento do pH, e início da ionização de grupamentos ácidos e fenólicos, houve o aparecimento de uma outra região que compreende partículas de tamanhos maiores. Nos valores de $\mathrm{pH}$ igual a 7 e 12 esse comportamento foi observado, permanecendo em solução partículas na faixa até $1500 \mathrm{~nm}$, 
bem como partículas que compreendem, de modo geral, faixas de tamanho da ordem 4000 a $6000 \mathrm{~nm}$. Estes resultados corroboram com os apontamentos de (PÉDROT et al., 2010), os quais remetem à distribuição de tamanho das substâncias húmicas envolvendo a ocorrência simultânea de pequenas moléculas e associações supramoleculares.

Observa-se, ainda, que nas amostras de E100, em especial das profundidades de 10-20 a 80-100 cm, há uma distribuição de tamanho diferenciada não observada para as amostras TEST e AM. Verifica-se, nestas profundidades de E100, como mostra a Figura 47, que em valores de $\mathrm{pH}$ iguais a 7 e 12, uma terceira faixa de tamanho adquire maior intensidade, compreendendo a faixa de tamanho entre 500 e $1500 \mathrm{~nm}$, aproximadamente. Isto sugere de certo modo, uma influência decorrente da aplicação do efluente, e pode ter ocorrido pela existência de diversos fatores como a adição de elementos metálicos provenientes do efluente que atuam ligando as estruturas ou o efeito da matéria orgânica recente presente no efluente aportada no solo. Entretanto, cabe ressaltar que estudos mais aprofundados devem ser conduzidos de modo a elucidar este comportamento descrito e suas razões. Este assunto, como argumentam PÉDROT et al. (2010), pertence a uma linha de estudos ainda escassa na literatura. 


\section{CAPÍTULO 6 - CONSIDERAÇÕES FINAIS}

Após avaliação dos parâmetros investigados para o efluente gerado pelo biodigestor anaeróbio, pode-se concluir que se trata de um material que possui quantidades significativas de nutrientes que possivelmente podem ser empregados na agricultura e disponibilizados para as plantas.

Entretanto, estudos mais aprofundados seriam de grande relevância para auxiliar na determinação e criação de limites de aplicação que controlem o aporte desse material no meio ambiente, levando-se em consideração a avaliação do efeito do efluente por períodos de de tempo maiores, outras culturas, a qualidade do efluente a ser aplicado e a área que receberia esse material. Esses cuidados tornam-se necessários, uma vez que o efluente analisado neste trabalho apresenta teores consideráveis de sódio, o que poderia acarretar danos ao solo, apesar de que nas amostras estudadas não observou-se efeitos expressivos de salinização.

A adição do efluente no solo não provocou modificação expressiva em suas propriedades físico-químicas, a não ser pelas análises de condutividade, que mostraram alterações significantes.

Pode-se concluir também, pelas técnicas de fluorescência e de determinação de teores de carbono que o tempo de duração do experimento de campo não foi suficiente para observar alterações mais significativas em relação à incorporação da matéria orgânica aportada pelo efluente no solo. A análise de PCA realizada com os dados obtidos pelos espectros de infravermelho médio, contudo, sugerem em relação à distribuição de grupos funcionais nos ácidos húmicos, que de certo modo, há alguma diferença (notada pela separação observada na PCA) entre as amostras que receberam aplicações com efluente seja qual for a dosagem e as que não receberam.

A utilização de ferramentas como a PCA e planejamento fatorial foram de grande relevância para a análise dos resultados e condução dos experimentos.

As medidas de potencial zeta corresponderam aos resultados esperados na literatura, do ponto de vista do comportamento das substâncias húmicas submetidas à algumas condições específicas de $\mathrm{pH}$ e concentração iônica. Os resultados obtidos para amostras de ácidos húmicos em relação ao tamanho de partículas evidenciaram um comportamento notado em estudos bastante recentes, porém escassos ainda na literatura. Tais medidas demonstraram que há um comportamento interessante no que tange à estrutura dos ácidos húmicos em solução, nas condições estudadas, pois sugerem associações correspondentes às teorias macro e supramolecular das substâncias húmicas. Esta linha, entretanto, requer mais aprofundamento e continuidade em estudos posteriores. 
As técnicas químicas e espectroscópicas mostraram que podem ocorrer alterações em algumas características do solo proporcionadas pela adição de efluente. Entretanto, por se tratar de um experimento de curta duração, estudos mais aprofundados com outros tipos de solo e culturas tornam-se necessários. 


\section{REFERÊNCIAS}

ALEM SOBRINHO, P. “Tratamento de esgoto e geração de lodo”. In: TSUTIYA, M.T.; COMPARINI, J.B.; ALEM SOBRINHO, P.; HESPANHOL, I.; CARVALHO, de P. de C.T. de; MELFI, A.J.; MELO, W.J. de; MARQUES, M.O. (Ed.). Biossólidos na agricultura. São Paulo: Companhia de Saneamento Básico do Estado de São Paulo, 2001. p. 7-40.

ALMEIDA, T.L. Implicações ambientais dos processos de atenuação de lixiviado em local de disposição de resíduos sólidos urbanos. 2009. 323p. Tese (Doutorado em Hidráulica e Saneamento) - Escola de Engenharia de São Carlos, Universidade de São Paulo, São Carlos, 2009.

ALVAREZ-PUEBLA, R. A.; ARCEO, E.; GOULET, P. J. G.; GARRIDO, J. J.; AROCA, R. F. Journal of Physical Chemistry B 2005, 109, 3787-3792.

ANDRADE, J.E. Síntese, caracterização e modificação de nanopartículas de prata com 5Fluorouracil sob a influência do pH. Universidade Federal de Sergipe. 2008. 97 p.

APHA; AWWA; WPCF. Standart methods for the examination of Water and Wastewater. 20. ed. Washington: American Public Health Association / American Water Works Association / Water Environment Federation, 1998.

BALDISSERA, I. T. Poluição por dejetos de suínos no Oeste Catarinense. Agropec. Catarin., v. 15, n. 1, p. 11-12, mar. 2002.

BATAGLIA, O.C.; BERTON, R.S.; CAMARGO, O.A.; VALADARES, J.M.A.S. "Residuos orgânicos como fontes de nitrogênio para capim-braquiária". Revista Brasileira de Ciências do Solo, v. 7, p. 277-284, 1983.

BAYER, C.; MARTIN-NETO, L.; MIELNICZUK, J.; CERETTA, C.A. Fracionamento da matéria orgânica e sua avaliação qualitativa por EPR num solo submetido dez anos a diferentes sistemas de cultura em plantio direto. In: SIMPÓSIO NACIONAL DE INSTRUMENTAÇÃO AGROPECUÁRIA, 1., 1996, São Carlos. Anais... São Carlos: Embrapa Instrumentação Agropecuária, 1997. p. 115-121.

BIEROLAI, H.; VAISMAN, I.; FEIGIN, A. "Drip irrigation of cotton with treated municipal effluents: I. Yield response". Journal of Environmental Quality, v.13, p. 231-234, 1984.

BOUWER, H; IDELOVITCH, E. "Quality requirements for irrigation with sewage water". Journal of Irrigation and Drainage Engineering, v. 113, p. 516-535, 1987

BROWN, L.R.; RENNER, M.; HALWEIL, B. Sinais vitais 2000: as tendências ambientais que determinarão nosso futuro. Salvador: UMA, 2000. 196 p.

BUDZIAK, C.R.; MAIA, C.M.B.F.; MANGRICH, A.S. "Transformações químicas da matéria orgânica durante a compostagem de resíduos da indústria madeireira". Química Nova, v. 27, n. 3, p. 399-403, 2004.

BURDON, J. Are the traditional concepts of the structures of humic substances realistic? Soil Scicience, v. 166, p. 752 -769, 2001. 
CANELLAS, L. P.; MENDONÇA, E. S.; DOBBSS, L. B.; BALDOTTO, M. A.; VELOSO A. C. X.; SANTOS, G. A.; AMARAL SOBRINHO, N. M. B. Reações da matéria orgânica. In: SANTOS, G.de A.; CAMARGO, F.A.de O. (Eds.) Fundamentos da matéria orgânica do solo: ecossistemas tropicais e subtropicais. Porto Alegre: Metrópole, 2008, p.45-61.

CANTARELLA, H.; QUAGGIO, J.A.; VAN RAIJ, B. Determinação da matéria orgânica. In: VAN RAIJ, B.; ANDRADE, J.C.; CANTARELLA, H.; QUAGGIO, J.A. (Eds). Análise química para avaliação da fertilidade de solos tropicais. Campinas: UNICAMP, 2001, cap.9, p. 173-180.

CARVALHO, E.R.; MARTIN-NETO, L.; MILORI, D.M.B.P.; ROCHA, J.C.; ROSA, A.H. "Interactions of chlorine with tropical aquatic fulvic acids and formation of intermediates observed by fluorescence spectroscopy". Journal of the Brazilian Chemical Society, v. 15, n. 53, p. 421-426, 2004.

CASTANHO, D.S.; ARRUDA, H.J. Biodigestores. In: IV Semana de tecnologia em alimentos. 2008. Anais...Ponta Grossa-PR.

CELI, L.; SCHNITZER, M.; NÈGRE, M. “Analysis of carboxil groups in soil humic acids by a wet chemical method, fourier-transform infrared spectrophotometry, and solution state carbon-13 nuclear magnetic resonance. A comparative study". Soil Science, v. 162, n. 3, p. 189-197, 1997.

CERETTA, C. A. et al. Característica química de solo sob aplicação de esterco líquido de suíno em pastagem natural. Pesq. agrop. bras., Brasília, v. 38, n. 6, p. 729-735, jun. 2003.

CHRISTOFIDIS, D. Olhares sobre a política de recursos hídricos no Brasil: o caso da bacia do rio São Francisco. Brasília: Universidade de Brasília, Brasília DF, 2001. 424p.

COÛTEAUX, M.M.; BJORN, B. ROVIRA, P. Near infrared reflectance spectroscopy for determination of organic matter fractions including microbial biomass in coniferous forest soils. Soil Biology and Biochemistry, v.35, p. 1587-1600, 2003.

CUNHA, L. "Uso do biodigestor para tratamento de dejetos de suínos". Dissertação de Mestrado. Universidade Federal de Santa Catarina, 2007. 72 p.

DA SILVA, W.T.; KUROKI, V.; MARTELLI, L.F.A.; NOVAES, A.P. “Avaliação físicoquímica de elfuente gerado em biodigestor anaeróbio para fins de avaliação de eficiência e aplicação como fertilizante agrícola”, Química Nova, 2010. (Submetido)

DIALLO, M.S. ; SIMPSON, A.J. ;GASSMAN, P. ; FAULON, J.L. ; JOHNSON, J.H. ; GODDARD, W.A. ; HATCHER, P.G. 3-D Structural modeling of humic acids through experimental characterization, computer assisted structure elucidation and atomistic simulations. Environmental Science \& Technology, v. 37, p. 1783-1793, 2003.

FAUSTINO, A.S. "Estudos físico-químicos do efluente produzido por fossa séptica biodigestora e o impacto do seu uso no solo"; Dissertação de mestrado, 2007, 120 p.

FERRARESI, T.M. "Espectroscopias de infravermelho próximo e médio na quantificação de atributos do solo, com ênfase na matéria orgânica e na biomassa microbiana"; Dissertação de mestrado, 2010, 119 p. 
FIRME, P.F. Efeito da irrigação com efluente de esgoto tratado no sistema solo-planta em Latossolo cultivado com cana-de-açúcar. 2007. 110f. Tese (Doutorado em Agronomia) Escola Superior de Agricultura Luiz de Queiroz, Universidade de São Paulo, Piracicaba, 2007.

FONSECA, A. F.; ALLEONI, L. R. F. ; MELFI, A.J.; MONTES, C.R. "Cation exchange capacity of an Oxisol amended with an effluent from domestic sewage treatment". Scientia Agricola, Brazil, v. 62, n. 6, p. 552-558, 2005.

FONSECA, A.F. Disponibilidade de nitrogênio, alterações nas características químicas do solo e do milho pela aplicação de efluente de esgoto tratado. 2001. 110f. Dissertação (Mestrado em Agronomia) - Escola Superior de Agricultura Luiz de Queiroz, Universidade de São Paulo, Piracicaba, 2001.

FONSECA, A.F.; MELFI, A.J.; MONTEIRO, F. A.; MONTES, C. R.; ALMEIDA, V.V.; HERPIN, U. "Treated sewage effluent as a source of water and nitrogen for Tifton 85 bermudagrass". Agricultural Water Management, Amsterdam, v. 87, p. 328-336, 2007.

FONTAINE, S.; BAROT, S.; BARRÉ, P.; BDIOUI, N.; MARY, B.; RUMPEL, C. 2007. Stability of organic carbon in deep soil layers controlled by fresh carbon supply. Nature, 450: 277-281.

GASPAR, R.M.B.L.; "Utilização de biodigestores em pequenas e médias propriedades rurais com ênfase na agregação de valor: um estudo de caso na região de Toledo-PR". Dissertação de Mestrado. Universidade Federal de Santa Catarina, 2003. 119 p.

GERZABEK, M. H.; ANTIL, R. S.; KOGEL-KNABNER, I.; KNICKER, H.; KIRCHMANN, H. HABERHAUER, G. How are soil use and management reflected by soil organic matter characteristics: a spectroscopic approach. European Journal of Soil Science, v.57, p.485-494, 2006.

GLOAGÜEN, T.V.; FORTI, M.C.; LUCAS, Y.; MONTES, C.R.; GONÇALVES, R. A.B.; HERPIN, U.; MELFI, A.J. Soil solution chemistry of a Brazilian Oxisol irrigated with treated sewage effluent. Agricultural Water Management, v. 88, p. 119-131, 2007.

GONZÁLEZ-PÉREZ, M.; MARTIN-NETO, L.; SAAB, S.C.; NOVOTNY, E.H.; MILORI, D.M.B.P.; BAGNATO, V.S.; COLNAGO, L.A.; MELO, W.J.; KNICKER, H.

Characterization of humic acids from a Brazilian Oxisol under different tillage systems by EPR, ${ }^{13}$ C NMR, FTIR and fluorescence spectroscopy. Geoderma, v. 118, p. 181-190, 2004.

GRUBE, M.; LIN, J.G.; LEE, P.H.; KOKOREVICHA, S. "Evaluation of sewage sludgebased compost by FTIR spectroscopy”. Geoderma, v. 130, p. 324-333, 2006.

GUINGAB, J. D.; LAULY, B.; SMITH, B. W.; OMENETTO, N.; WINEFORDNER, J. D. Talanta 2007, 74, 271-274.

HERPIN, U.; GLOAGÜEN, T.V.; FONSECA, A.F.; MONTES, C.R.; MENDONÇA, F.C.; PIVELI, R.P.; BREULMANN, G.; FORTI, M.C.; MELFI, A.J. Chemical Effects on the soilplant system in a secondary treated wastewater irrigated coffee plantation - A pilot field study in Brazil. Agricultural Water Management, v. 89, p. 105-115, 2007. 
HUFFMAN JR., E.D.; STUBER, H.A. Analytical methodology for elemental analysis of humic substances. In: AIKEN, G.R.; McKNIGHT, D.M.; WERSHAW, R.L.; McCARTHY, P. (Eds) Humic Substances in soil, sediment and water: geochemistry, isolation and characterization. New York: John Wiley, 1985. P. 433-455.

INSTITUTO BRASILEIRO DE GEOGRAFIA E ESTATÍSTICA. "Indicadores de Desenvolvimento Sustentável - Brasil 2004. Dimensão Ambiental - Saneamento. Tratamento de Esgoto". Rio de Janeiro, RJ. p. 135-164, 2004.

INSTITUTO BRASILEIRO DE GEOGRAFIA E ESTATÍSTICA. "Pesquisa Nacional de Saneamento Básico - Brasil 2008”. Rio de Janeiro, RJ. p. 125-134, 2008.

JACKSON, J. D. Eletrodinâmica Clássica, 2 ed.; São Paulo, 1981.

JACKSON, M.L. Analisis químico de suelos. Barcelona: Ediciones Omega, 1982. P. 282309.

JANIK, L.J., MERRY, R.H., SKJEMSTAD, J.O. Can mid infra-red diffuse reflectance analysis replace soil extractions? Australian Journal of Experimental Agriculture, v. 38, n.7, p. 681-696, 1998.

JEYASEELAN, S. "A simple mathematical model for anaerobic digestion process". Water Science Technology, v. 35, p. 185-191, 1997.

JIMENEZ, R.R.; LADHA, J.K. Automated elemental analysis: a rapid and reliable but expensive measurement of total carbon and nitrogen in plant and soils samples.

Communicantions in Soil Science and Plant Analysis, v. 24, n. 15-16, p. 1897-1924, 1993.

JUNIOR, A.H.A.; MARTIN-NETO, L.; MILORI, D.M.B.P.; SIMÕES, M.L.; SILVA, W.T.L. Métodos Analíticos utilizados em química do solo. In: Vander de Freitas Melo; Luis Reynaldo F. Alleoni. (Org.). Química e Mineralogia do Solo. $1^{\text {a }}$ ed. Viçosa: Sociedade Brasileira de Ciência do Solo, 2009, v. II, 685 p.

KALBITZ, K.; GEYER, S.; GEYER, W. "A comparative characterization of dissolved organic matter by means of original aqueous samples and isolated humic substances". Chemosphere, v. 40, p. 1305-1312, 2000.

KUNZ, A., HIGARASHI, M. M., Oliveira, P.A., MATEI, R. M., MIGUEL, W. C. Utilização de Biodigestor Abastecido com dejetos de Suínos em uma pequena Propriedade Rural In: III Simpósio Gaúcho de Educação Ambiental, 2004, Erechim.

KUNZ, A.; MIELE, M.; STEINMETZ, R.L.R. “Advanced swine manure treatment and utilization in Brazil”. Bioresource Technology. 100, p. 5485-5489, 2009.

LEITE, C. M. B.; BERNARDES, R. S.; OLIVEIRA, S. A. "Método de Walkley-Black na determinação da matéria orgânica em solos contaminados por chorume". Revista Brasileira de Engenharia Agrícola e Ambiental, v. 8, n. 1, p. 111-115, 2004. 
LUDWIG, B.; KHANNA, P. K.; BAUHUS, J.; HOPMANS, P. Near infrared spectroscopy of forest soils to determine chemical and biological properties related to soil sustainability. Forest Ecology and Management, v. 171, p. 121-132, 2002.

MADARI, B. E.; REEVES III, J. B.; COELHO, M.R.; MACHADO, P.L.O.A.; DE-POLLI, H.; COELHO, R.M.; BENITES, V.M.; SOUZA, L.F.; MCCARTY, G.W. Mid- and Nearinfrared Spectroscopic Determination of Carbon in a Diverse Set of Soils from the Brazilian National Soil Collection. Spectroscopy Letters. v. 38, p. 721-740. 2005.

MADARI, B. E.; REEVES, J. B.; MACHADO, P. O. A.; GUIMARÃES, C. M.; TORRES, E.; McCARTY, G.W. Mid- and near-infrared spectroscopic assessment of soil compositional parameters and structural indices in two Ferrasols. Geoderma,v.136, p.1-15, 2006a.

MAGALHÃES, D.I.; ALMEIDA, E.C.; CARVALHO, M.G.P.; SILVA, L.A.; SANTAELLA, S.T. Avaliação da produção de feijão caupi (Vigna unguiculata L. Walps) através da disposição de esgoto no solo por infiltração subsuperficial. $23^{\circ}$ Congresso Brasileiro de Engenharia Sanitária e Ambiental, Anais, 2005.

MALAVOLTA, E. Manual de Química Agrícola: nutrição de plantas e fertilidade do solo. São Paulo: Agronômica Ceres, 1976.

MALVERN Instruments Zetasizer Nano User Manual, Worcestershire, 2007.

MARTIN-NETO, L.; MILORI, D. M. P. B.; SILVA, W.T.L.; SIMÕES, M. L. EPR, FTIR, Raman, UV-visible Absorption and Fluorescence Spectroscopies in studies of NOM. In: Nicola Senesi; Baoshan Xing; Pan Ming Houang. (Org).Biophysico-Chemical Processes involving natural nonliving organic matter in environmental systems. $1^{\text {st }}$ Ed. England, 2009, p. 675-692.

MARTIN-NETO, L.; MILORI, D.M.B.P.; DA SILVA, W.T.L.(Eds.) Humic Substances and Soil and Water Environment. São Carlos: Rima, 2004.

MARTIN-NETO, L.; NASCIMENTO, O.R.; TALAMONI, J.; POPPI, N.R. EPR of micronutrients-humic substances complexes extracted from brazilian soil. Soil Science, v. 151, p. 369-376, 1991.

MC PHIE, P. "Enzyme Purification and Related Techniques: dialysis". In: JACOBY, W. B. (Ed.). Methods in Enzymology. New York: Academic Press, 1971. v. 22, p. 25-175.

MCCARTY, G. W.; REEVES III, J. B.; REEVES, V. B.; FOLLETT, R. F.; KIMBLE, J. M. Mid-infrared and near-infrared diffuse reflectance spectroscopy for soil carbon measurement. Soil Science Society of America Journal v. 66, p. 640-646, 2002.

MELFI, A.J.; MONTES, C. R. "Impacto dos biossólidos sobre o solo". In: TSUTIYA, M.T.; COMPARINI, J.B.; ALEM SOBRINHO, P.; HESPANHOL, I.; CARVALHO, de P. de C.T. de; MELFI, A.J.; MELO, W.J. de; MARQUES, M.O. (Eds.). Biossólidos na agricultura. São Paulo: Companhia de Saneamento Básico do Estado de São Paulo, 2001. p. 243-287.

MELO, W. J.; MARQUES, M. O.; SANTIAGO, G.; CHELLI, R. A.; LEITE, S. A. S. "Efeito de doses crescentes de lodo de esgoto sobre frações da matéria orgânica e CTC de um 
latossolo cultivado com cana de açúcar”. Revista Brasileira de Ciência do Solo, v. 18, p. 449$455,1994$.

METZER, L.; YARON, B. "Influence of sludge organic matter on soil physical properties". Soil Science, v. 7, p. 141-163, 1987.

MILORI, D. M. B. P.; GALETI, H. V. A.; MARTIN-NETO, L.; DIEKOW, J.; GONZÁLEZPÉREZ, M.; BAYER, C.; SALTON, J. "Organic matter study of whole soil sample using laser-induced fluorescence spectroscopy”. Soil Science Society American Journal, v. 70, p. 57-63, 2006.

MILORI, D. M. B. P.; MARTIN-NETO, L.; BAYER, C.; MIELNICZUK, J.; BAGNATO, V. $\mathrm{S}$. Humification degree of soil humic acids determined by fluorescence spectroscopy. Soil Science, v. 167, p. 739-749, 2002.

MILORI, D.M.B.P.; GALETI, H.V.A.; MARTIN-NETO, L.; GONZÁLEZ-PÉREZ, M.; BAYER, C.; MIELNICZUK, J.; SALTON, J. "Humification degree of organic matter in whole soil determined by laser-induced fluorescence". In: MARTIN-NETO, L.; MILORI, D.M.B.P.; DA SILVA, W.T.L.(Eds.) Humic Substances and Soil and Water Environment. São Carlos: Rima, p.609, 2004.

MILORI, D.M.B.P.; MARTIN-NETO, L.; BAYER, C.; MIELNICZUK, J.; BAGNATO, V.S. "Humification degree of soil humic acids determined by fluorescence spectroscopy". Soil Science, v. 167, n.11, p. 739-749, 2002.

MITTELMANN, A.; SOBRINHO, F.S.; OLIVEIRA, J.S.; FERNANDES, S.B.V.; LAJÚS, C.A.; MIRANDA, M.; ZANATTA, J.C.; MOLETTA, J.L. Avaliação de híbridos comerciais de milho para utilização como silagem na Região Sul do Brasil. Ciência Rural, v. 35 n. 3, p. 684-690, 2005.

MONTES, C.R.; TAKAYUKIKATO, M.; SOUZA, M.A.A.; FILHO, C.; JUNIOR, J.M. Irrigação com esgotos tratados: impactos no solo e no aqüífero. In: FLORENCIO, A.; BASTOS, R. K. X.; ASSIE, M.M. Tratamento e utilização de esgotos sanitários. Rio de Janeiro: ABES/RiMa, 2006. p.115-200.

MOREIRA, F. M. S.; SIQUEIRA, J. O. Microbiologia e bioquímica do solo. Lavras: Editora UFLA, 2.a ed., 2006. 729 p.

MOTA, S.; FONSECA, A.F.; STEFANUTTI, R.; VOLSCHAN, I.JR. NAVAL, L. Irrigação com esgotos tratados sanitário e efeitos nas plantas. In: FLORENCIO, A.; BASTOS, R. K. X.; ASSIE, M.M. Tratamento e utilização de esgotos sanitários. Rio de Janeiro: ABES/RiMa, 2006. p.202-238

NAIDJA, A.; HUANG, P.M.; ANDERSON, D.W.; VAN KESSEL, C. "Fourier transform infrared, UV-Visible, and X-ray diffraction analysis of organic matter in humin, humic acid, and fulvic acid fractions in soil exposed to elevated $\mathrm{CO}_{2}$ and $\mathrm{N}$ fertilization". Applied Spectroscopy, v. 56, n. 3, p. 318-324, 2002.

NARIMOTO, K.M. "Técnicas espectroscópicas aplicadas à análise da matéria orgânica do solo em pomares de citros sob adição de lodo de esgoto". Dissertação (Mestrado em Ciências 
- Química Analítica) - Instituto de Química de São Carlos, Universidade de São Paulo, São Carlos, 2006. 112p.

NGOLE, V.; MPUCHANE, S.; TOTOLO, O. "Survival of faecal coliforms in four different types of sludge-amended soils in Botswana". European Journal of Soil Biology, v. 42, p.208$218,2006$.

NIEMEYER, J.; CHEN, Y.; BOLLAG, J.M. "Characterization of humic acids, composts, and peat by diffuse reflectance Fourier transform infrared spectroscopy". Soil Science Society of America Journal, v. 56, p. 135-140, 1992.

NOGUEIRA, A. R. de A.; SOUZA, G. B. de (Ed). Manual de laboratórios: solo, água, nutrição vegetal, nutrição animal e alimento. São Carlos, SP: Embrapa Pecuária Sudeste, 2005. 334 p.

NOVAES, A.P.; SIMÕES, M.L.; MARTIN-NETO, L.; CRUVINEL, P.E.; SANTANA, A.; NOVOTNY, E. H.; SANTIAGO, G.; NOGUEIRA, A.R.A. "Utilização de uma fossa séptica para melhoria do saneamento rural e desenvolvimento da agricultura orgânica". Comunicado Técnico 46. Embrapa Instrumentação Agropecuária, São Carlos, 2002.

$\mathrm{OHNO}, \mathrm{T}$. "Fluorescence inner-filtering correction for determining the humification index of dissolved organic matter”. Environmental Science Technology, v. 36, p. 742-746, 2002.

OLIVEIRA, F. C.; MATTIAZO, M, E.; MARCIANO, C. R.; ROSSETTO, R. "Efeitos de aplicações sucessivas de lodo de esgoto em um latossolo amarelo distrófico cultivado com cana de açúcar: carbono orgânico, condutividade elétrica, pH e CTC". Revista Brasileira de Ciência do Solo, v. 26, p. 505-519, 2002.

OLIVEIRA, P. A. V. Produção e aproveitamento do biogás. In: Oliveira, P. A. V. Tecnologias para o manejo de resíduos na produção de suínos: manual de boas práticas.Concórdia: Embrapa Suínos e Aves, 2004. 109 p.

PAL, A.; SHAH, S.; DEVI, S. Colloids and Surfaces A-Physicochemical and Engineering Aspects 2007, 302, 483-487.

PALHARES, J.; BARIONI JUNIOR, W.; JACOB, A. D.; PERDOMO, C.C. Impacto ambiental da concentração de suínos na microbacia hidrográfica do rio Fragosos. Comunicado Técnico, n. 307. Embrapa, Concórdia, 2002.

PÉDROT, M.; DIA, A.; DAVRANCHE, M.; "Dynamic structure of humic substances: Rare earth elements as a fingerprint”. Journal of Colloid and Interface Science, 345 p. 206-213, 2010 .

PESCOD, M.B. Wastewater treatment and use in agriculture. Rome: Food and Agriculture Organization, 1992. 125p. (Irrigation and Drainage Paper, 47).

PICCOLO, A. The supramolecular structure of humic substances. Soil Scicience, v. 166, p. 810-832, 2001.

REEVES, D.W. "The role of soil organic matter in maintaining soil quality in continuous cropping systems". Soil and Tillage Research, v. 43, p. 131-167, 1997. 
REZENDE, M.O.O. A importância ambiental das substâncias húmicas. São Carlos, 1999. 147 f. Tese (Livre Docência) - Instituto de Química de São Carlos, Universidade de São Paulo, São Carlos, 1999.

ROCHA, J. C., ROSA, A. H., CARDOSO, A. A. Introdução a Química Ambiental. 256 p . Editora Bookman, Porto Alegre, 2009.

SAAB, S. C. "Caracterização da matéria orgânica em gleissolos por espectroscopias de EPR, RMN, IV e UV-Visível”. Tese (Doutorado em Química Analítica) - Instituto de Química de São Carlos, Universidade de São Paulo, São Carlos, 1999. 111p.

SAAB, S.C.; CARVALHO, E.R.; FILHO, R.B.; MOURA, M.R.; MARTIN-NETO, L.; MATTOSO, L.H.C. "pH Effect in Aquatic Fulvic Acid from Brazilian River". J. Braz. Chem. Soc., Vol. 00, No. 00, 1-7, 2010.

SAADI, I.; BORISOVER, M.; ARMON, R.; LAOR, Y. "Monitoring of effluent DOM biodegradation using fluorescence, UV and DOC measurements". Chemosphere, v. 63, p. 530-539, 2006.

SANTOS, A.P.R. dos. Efeito da irrigação com efluente de esgoto tratado, rico em sódio, em propriedades químicas e físicas de um argissolo distrófico cultivado com capim-Tifton 85 . 2004. 79f. Dissertação (Mestrado na área de Solos e Nurição de Plantas) - Escola Superior de Agricultura Luiz de Queiroz, Universidade de São Paulo, Piracicaba, 2004.

SANTOS, L.M.; MILORI, D.M.B.P.; SIMÕES, M.L.; DA SILVA, W.T.L.; PEREIRAFILHO, E.R.; MELO, W.J.; MARTIN-NETO, L. Characterization by Fluorescence of Organic Matter from Oxisols under Sewage Sludge Applications. Soil Sci. Soc. Am. J., v. 74, n.1, 94-104, 2010.

SCHULTEN, H. R., SCHNITZER, M. "A state of the art structural concept for humic substances". Naturwissenschaften, v. 80, p. 29-30, 1993.

SCHULTEN, H. R.; SCHNITZER, M. "Chemical model structures for soil organic matter and soils”. Soil Science, v. 162, p. 115-130, 1997.

SEGANFREDO et al. Visualizando além dos benefícios, na análise do uso dos dejetos de animais como fertilizante. In: REUNIÃO BRASILEIRA DE MANEJO E CONSERVAÇÃO DO SOLO E DA ÁGUA, 15., 2004, Santa Maria, RS. Anais... Santa Maria: SBCS, 2004. CDROM.

SEGNINI, A. Estrutura e estabilidade da matéria orgânica em áreas com potencial de seqüestro de carbono no solo. 2007. Tese de Doutorado. Instituto de Química de São Carlos. $131 \mathrm{p}$.

SEGNINI, A.; SANTOS, L.M.; LOPES da SILVA, W.T.; BORATO, C.E.; MELO, W.J.; BOLNHEZI,D.; MARTIN;NETO, L.Estudo comparativo de métodos para a determinação da concentração de carbono em solos com altos teores de Fe (Latossolos). Química Nova, v. 31, p. $94 ; 97,2008$.

SENESI, N.; LOFFREDO, E. “The Chemistry of Soil Organic Matter”. In: SPARKS, D. L. (Ed.) Soil physical chemistry. Boca Raton: CRC, 1999, p. 242-370. 
SENESI, N.; MIANO, T. M.; PROVENZANO, M. R.; BRUNETTI, G. "Characterization, differentiation, and classification of humic substances by spectroscopy". Soil Science, v. 152, n. 4, p. 259-271, 1991.

SENESI, N.; MIANO, T. M.; PROVENZANO, M. R.; BRUNETTI, G. "Characterization, differentiation, and classification of humic substances by spectroscopy". Soil Science, v. 152, n. 4, p. 259-271, 1991.

SENESI, N.; RIZZI, F.R.; DELLINO, P.; ACQUAFREDDA, P. Fractal dimension of humic acids in aqueous suspension as a function of $\mathrm{pH}$ and time. Soil Science of America Journal, v. 60, p. 1773 - 1780, 1996.

SILVERSTEIN, R.M.; WEBSTER, F.X. Identificação Espectrométrica de Compostos Orgânicos. 6 ed. Rio de Janeiro: Livros Técnicos e Científicos Editora, 2000. 460p.

SIMIONI, J. “Avaliação dos riscos ambientais pela acumulação de $\mathrm{Cu}$ e $\mathrm{Zn}$ nos solos fertilizados com dejetos de suínos. Dissertação (mestrado). Universidade Federal de Santa Catarina, 2001. 139 p.

SIMÕES, M.” Estudos de interações hidrofóbicas em substâncias húmicas e componentes do solo utilizando análises espectroscópicas". Tese de Doutorado. Ciência e Engenharia de Materiais. 2005. 165 p.

SIMONETE, M.A.; KIEHL, J.C.; ANDRADE, C.A.; TEIXEIRA, C.F.A. "Efeito do lodo de esgoto em um argissolo de no crescimento de nutrição do milho". Pesquisa Agropecuária Brasileira, v. 38, p. 1187, 2003.

SIMPSON, A. J. "Determining the molecular weight, aggregation, structures and interactions of natural organic matter using diffusion ordered spectroscopy". Magnetic Resonance in Chemistry, v. 40, p.72-80, 2002.

SIMPSON, A. J.; KINGERY, W. L.; SWAW, D. R.; SPRAUL, M.; HUMPFER, E.; DVORTSAK, P. "Molecular structures and associations of humic substances in the terrestrial environment”. Naturwissenschaften, v. 89, p. 84-88, 2002.

SKOOG, D. A.; HOLLER, F. J.; NIEMAN, T. A. Análise Instrumental. 5. ed. Porto Alegre: Bookman, 2002. 836p.

SOUSA, J.T. de; LEITE, V.D.; LUNA, J.G. de. "Desempenho da cultura de arroz irrigado com esgotos sanitários previamente tratados". Revista Brasileira de Engenharia Agrícola e Ambiental. v. 5, n.1, p. 107-110, 2001.

SPOSITO, G. The chemistry of soils. New York: Oxford University Press, 1989. 277p.

STEVENSON, F.J. Humics Chemistry: genesis, composition, reactions. New York: John Wiley, 1994. 443p.

STEVENSON, F.J. Humics Chemistry: genesis, composition, reactions. New York: John Wiley, 1994. 443p.

STUART, B. Modern Infrared Spectroscopy: Analytical Chemistry by Open Learning. New York: John Wiley, 1996. 179p. 
SWIFT, R.S. "Organic matter characterization". In: SPARKS, et al. (Eds.) Methods of soil analysis. Part 3. Chemical methods. Soil Science Society of America Journal. Book Series: 5 Madison, Soil Science Society of America Journal, p. 1018-1020, 1996.

SWIFT, R.S. Macromolecular properties of soil humic substances: fact, fiction, and opinion. Soil Science, v. 164, p. 760-802, 1999.

TATZBER, M.; STEMMER, M.; SPIEGEL, H.; KATZLBERGER, C.; HANERNHAUER, G.; GERZABEK, M.H. Impact of different tillage practices on molecular characteristics of humic acids in a long-term field experiment - An application of three different spectroscopic methods. Science of the Total Environment, v. 406, p. 256-268, 2008.

TOMÉ Jr., J.B. Manual para interpretação de análise de solo. Guaíba: Agropecuária, 1997. $247 \mathrm{p}$.

VAN RAIJ, B.; ANDRADE, J.C.; CANTARELLA, H.; QUAGGIO, J.A. Análise química para avaliação da fertilidade de solos tropicais. Campinas, Instituto Agronômico, 2001. 285p.

VERGNOUX, A.; DUPUY, N.; GUILIANO, M.; VENNETIER, M.; THÉRAULAZ, F.; DOUMENQ, P. Fire Impact on forest soils evaluated using near-infrared spectroscopy and multivariate calibration. Talanta, v. 80, p. 39-47, 2009.

VISCARRA-ROSSEL, R.A.; WALVOORT, T.D.J.J.; MCBRATNEY, A.B.; JANIK, L.J.; SKJEMSTAD, J.O. Visible, near infrared, mid infrared or combined diffuse reflectance spectroscopy for simultaneous assessment of various soil properties. Geoderma, v. 131, p. 5975, 2006.

VO-DINH, T. "Multicomponent analysis by synchronous luminescence spectrometry". Anayitical Chemistry. v. 50, p. 396-401, 1978.

WALKLEY, A.; BLACK, I.A. An examination of the Degtjareff method for determining soil organic matter and a proposed modification of the cromic acid titration method. Soil Science, v. 37, p. 29-38, 1934.

WESTAD, F.; SCHMIDT, A.; KERMIT, M. Incorporating band-assignment in near infrared spectroscopy regression models. Journal of Near Infrared Spectroscopy, v. 16, p. 265-273, 2008.

WORKMAN, J. R. Optical Spectrometers. In: WORKMAN J. R., J.; SPRINSTEEN, A. (Eds.) Applied spectroscopy: a compact reference for practitioners. San Diego-USA: Academic Press, 1998, p. 4-91.

ZECH, W.; SENESI, N.; GUGGNBERGER, G.; KAISER, K.; LEHMANN, J.; MIANO, T. M.; MILTNER, A.; SCHROTH, G. Factors controlling humification and mineralization of soil organic matter in the tropics. Geoderma, v. 79, p. 117-161, 1997.

ZUQUETTE, L.V.; PEJON, O.J.; GANDOLFI, N.; SINELLI, O. - "Carta do potencial de risco à contaminação das águas subterrâneas e do potencial agrícola, região de Ribeirão Preto, SP, Brasil", Geociências, v.12, no 2, p.531-540, 1993. 